FRANCIELLI MAHNIC DE VASCONCELLOS

PADRÃO DE ADESÃO AGREGATIVA E FORMAÇÃO DE BIOFILME EM Escherichia coli ENTEROAGREGATIVA TÍPICA E ATÍPICA: PAPEL DA PROTEÍNA Shf

Dissertação apresentada ao Programa de Pós-Graduação em Microbiologia do Instituto em Ciências Biomédicas da Universidade de São Paulo, para obtenção do Título de Mestre em Ciências. 
FRANCIELLI MAHNIC DE VASCONCELLOS

\section{PADRÃO DE ADESÃO AGREGATIVA E FORMAÇÃO DE BIOFILME EM Escherichia coli ENTEROAGREGATIVA TÍPICA E ATÍPICA: \\ PAPEL DA PROTEÍNA Shf}

Dissertação apresentada ao Programa de Pós-Graduação em Microbiologia do Instituto de Ciências Biomédicas da Universidade de São Paulo, para obtenção do Título de Mestre em Ciências.

Área de Concentração: Microbiologia

Orientador: Dr. Waldir Pereira Elias Júnior

\section{São Paulo}


DADOS DE CATALOGAÇÃO NA PUBLICAÇÃO (CIP)

Serviço de Biblioteca e Informação Biomédica do

Instituto de Ciências Biomédicas da Universidade de São Paulo

(C) reprodução total

Vasconcellos, Francielli Mahnic de.

Padrão de adesão agregativa e formação de biofilme em Escherichia coli enteroagregativa típica e atípica: papel da proteína Shf / Francielli Mahnic de Vasconcellos. -- São Paulo, 2009.

Orientador: Waldir Pereira Elias Junior.

Dissertação (Mestrado) - Universidade de São Paulo. Instituto de Ciências Biomédicas. Departamento de Microbiologia. Área de concentração: Microbiologia. Linha de pesquisa: Mecanismos moleculares da patogênese de Escherichia coli diarreiogênicas.

Versão do título para o inglês: Aggregative adherence pattern and biofilm formation in typical and atypical enteroaggregative Escherichia coli: role of the Shf protein.

Descritores: 1. Escherichia coli 2 2. Virulência 3. Diarréia 4. Biofilmes I. Elias Junior, Waldir Pereira II. Universidade de São Paulo. Instituto de Ciências Biomédicas. Programa de Pós Graduação em Microbiologia III. Título. 
Candidato(a):

Título da Dissertação:

Orientador(a):
Francielli Mahnic de Vasconcellos.

Padrão de adesão agregativa e formação de biofilme em Escherichia coli enteroagregativa típica e atípica: papel da proteína Shf.

A Comissão Julgadora dos trabalhos de Defesa da Dissertação de Mestrado, em sessão pública realizada a ./...................................,
( ) Aprovado(a)
( ) Reprovado(a)

Examinador(a): Assinatura:

Nome:

Instituição:

Examinador(a): Assinatura:

Nome:

Instituição:

Presidente: Assinatura:

Nome:

Instituição: 


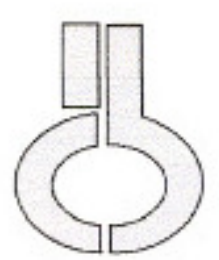

UNIVERSIDADE DE SÃO PAULO INSTITUTO DE CIÊNCIAS BIOMÉDICAS

Cidade Universitária "Armando de Salles Oliveira"

Av. Prof. Lineu Prestes, 2415 - CEP, 05508-000 São Paulo, SP - Brasil

Telefone :(55) (011) 3091.7733 - telefax : (55) (011) 3091.7438

e-mail: cep@icb.usp.br

Certificado

Certificamos que o protocolo registrado sob $n^{\circ} 147$ nas fls. 40 do livro 2 para uso de animais em experimentação, sob a responsabilidade de Waldir Pereira Elias Junior, Coordenador(a) da Linha de pesquisa "Padrão de adesão agregativa e formação de biofilme em escherichia coli enteroagregativa tipica e atipica: papel da proteina Shf' do qual participou(aram) o(s) alunos Francielli Mahnic de Vasconcellos, está de acordo com os Princípios Éticos de Experimentação Animal adotado pelo Colégio Brasileiro de Experimentação Animal (COBEA) e foi aprovado pela COMISSÃO DE ÉTICA EM EXPERIMENTAÇÃO ANIMAL (CEEA) em 27.02.2007.

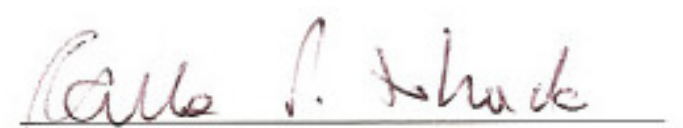

Prof. Dr. CARLOS PELLESCHI TABORDA Vice-Coordenador CEEA - ICB/USP
São Paulo, 27 de fevereiro de 2007.

Patricia basteluco

Profa. Dra. PATRÍCIA CASTELUCCI Secretária da CEEA - ICB/USP 
Aos meus pais, Carlos e Vera por sempre apoiarem as minhas decisões, e me incentivarem durante toda a minha vida. Às minhas irmãs, Michelli e Jacqueline pelo carinho, amizade e palavras amigas. 
Este trabalho foi desenvolvido no Laboratório de Bacteriologia do Instituto Butantan (São Paulo, SP), com o auxílio financeiro da Fundação de Amparo à Pesquisa do Estado de São Paulo (Processo 06/58302-9). 


\section{AGRADECIMENTOS}

Ao Dr. Waldir Pereira Elias Júnior, meu orientador durante este projeto, pelo incentivo e confiança, por todo o conhecimento transmitido e pela amizade durante esses anos.

À Dra. Roxane Fontes Piazza, por ter me recebido no laboratório de Bacteriologia, pela confiança, ajuda e sugestões no decorrer do projeto.

À Dra. Marcia Regina Franzolin, pela ajuda, disponibilidade e amizade.

À Dra. Patrícia A. de Abreu de Aniz pela preciosa ajuda e discussões para o melhor desenvolvimento do projeto.

Às Dras. Kinue Irino e Carla Taddei pela colaboração na sorotipagem das amostras utilizadas neste estudo.

Ao doutorando, Márcio A. Menezes, pela ajuda nos experimentos, por estar sempre disposto a ajudar, e pela amizade, almoços, cafés e baladas juntos.

Ao estagiário Luciano Bevilacqua pelas incontáveis ajudas no decorrer do projeto, pela disposição em ajudar e pela companhia durante esse tempo no laboratório.

Aos amigos de bancada Sergio, Vanessa, Bianca, Renato e Karina, pela ajuda, companheirismo e risadas.

À amiga Sarita S. Rossato, pela amizade, baladas, passeios, por sempre estar por perto e escutar as minhas reclamações, e por me ter que me agüentar todos os dias.

A todos os demais colegas do laboratório não citados, porém sempre lembrados, por todos esses anos de convivência, amizade e descontração.

Aos pesquisadores e funcionários do Laboratório de Bacteriologia, sempre prestativos.

À minha família por sempre me apoiarem e dividirem comigo todas as alegrias e tristezas mesmo que à distância, afinal são a razão por todo o esforço e dedicação para a finalização de mais uma etapa. 


\section{RESUMO}

VASCONCELLOS, F. M. Padrão de adesão agregativa e formação de biofilme em Escherichia coli enteroagregativa típica e atípica: papel da proteína Shf. 96 f. Dissertação (Mestrado em Microbiologia) - Instituto de Ciências Biomédicas, Universidade de São Paulo, São Paulo, 2009.

Escherichia coli enteroagregativa (EAEC) é considerada um enteropatógeno emergente, caracterizado pela expressão do padrão de adesão agregativa (AA) em células epiteliais cultivadas. Vários potenciais fatores de virulência de EAEC são codificados por genes localizados no plasmídeo de virulência pAA2 da amostra protótipo 042, incluindo o gene agg $R$, que codifica uma proteína reguladora de vários fatores de virulência de EAEC. A classificação de EAEC em típica e atípica se baseia na presença ou ausência do gene aggR, respectivamente. Um gene de 842 pb denominado shf, a qual codifica uma proteína predita de $32,8 \mathrm{kDa}$, também foi localizado no plasmídeo pAA2. Essa proteína apresenta $25 \%$ de similaridade com a proteína IcaB de Staphylococcus epidermidis, que possui relação na formação de biofilme dessa espécie. Os objetivos deste estudo foram verificar a prevalência do gene shf em amostras de EAEC isoladas no Brasil e caracterizar o envolvimento da proteína Shf na capacidade de formação de biofilme e no estabelecimento do padrão AA em EAEC típica e atípica. Cento e treze amostras de EAEC isoladas de crianças com diarréia na cidade de Salvador (BA) foram investigadas quanto à presença de shf e aggR. O gene shf foi detectado em 41 (36,3\%) amostras de EAEC. Através da detecção do gene aggR, essas amostras foram classificadas como típicas e atípicas. Desta forma, o gene shf foi detectado em 25 (37,3\%) EAEC típicas e em 16 (34,8\%) EAEC atípicas. As 41 amostras em que shf foi detectado foram analisadas quanto ao sorogrupo, adesão em células HEp-2 e capacidade de formar biofilme em poliestireno. Nenhuma dessas características foi associada com a presença de shf nos grupos de EAEC típica ou atípica e a formação de biofilme foi detectada em todas as amostras. Para avaliar o eventual envolvimento da proteína Shf nos fenótipos de AA e de formação de biofilme, foram realizadas mutagêneses não-polares no gene shf das amostras protótipo de EAEC típica (042) e atípica (2871-1). Os mutantes obtidos (042::pFV3 e 2871-1::pFV3) foram avaliados nos ensaios de adesão em células HEp-2 e de formação de biofilme em placas de poliestireno. Foi observado em ambos os mutantes uma drástica diminuição na capacidade de formação de biofilme e a incapacidade de aderir em células HEp-2. Este estudo demonstrou que, embora o papel de Shf na patogênese de EAEC não esteja esclarecido, o gene shf foi detectado em alta prevalência em amostras de EAEC isoladas no Brasil e Shf participa do estabelecimento do padrão $A A$, bem como da capacidade de formação de biofilme em EAEC típica e atípica. Além disso, shf não deve ser regulado exclusivamente por AggR, uma vez que o nocaute nesse gene na amostra de EAEC atípica (desprovida de aggR) aboliu os fenótipos avaliados, indicando que shf é expresso em EAEC atípica.

Palavras-chave: Diarréia; Escherichia coli enteroagregativa; Adesão; Biofilme. 


\begin{abstract}
VASCONCELLOS, F. M. Aggregative adherence pattern and biofilm formation in typical and atypical enteroaggregative Escherichia coli: role of the Shf protein. 96 p. Master thesis (Microbiology) - Instituto de Ciências Biomédicas, Universidade de São Paulo, São Paulo, 2009.
\end{abstract}

Enteroaggregative Escherichia coli (EAEC) is considered an emergent enteropathogen, characterized by the expression of the aggregative adherence (AA) pattern on cultured epithelial cells. Several EAEC putative virulence factors are encoded by genes located in the pAA2 virulence plasmid present in the prototype strain 042, including agg $R$ that encodes a regulator of several EAEC virulence factors. The classification of EAEC in typical and atypical is based on the presence or absence of aggR, respectively. A 842-pb gene named shf, which encodes a predicted protein of $32.8 \mathrm{kDa}$, has also been identified in the pAA2 plasmid. This protein presents $25 \%$ of similarity with the IcaB protein of Staphylococcus epidermidis, which has been associated with biofilm formation in this specie. The objectives of this study were to verify the prevalence of shf among EAEC strains isolated in Brazil, and to characterize the role of the Shf protein in the establishment of the AA pattern and biofilm formation of typical and atypical EAEC. One hundred and thirteen EAEC strains isolated from children with diarrhea in the city of Salvador (BA) were investigated regarding the presence of shf and aggR. The shf gene was detected in 41 (36,3\%) EAEC strains. By the presence of $a g g R$, these strains were classified as typical and atypical. Therefore, the shf gene was detected in $25(37,3 \%)$ typical EAEC and in $16(34,8 \%)$ atypical EAEC. The 41 strains that harbored shf were analyzed regarding their serogroups, adherence patterns to HEp-2 cells and the ability to form biofilm in polystyrene. None of these characteristics was associated with the presence of shf in the typical and atypical EAEC groups, and the capacity to form biofilm was detected in all strains. In order to evaluate the role of Shf in the AA and biofilm phenotypes, non-polar mutagenesis of shf were performed in the typical (042) and atypical (2871-1) EAEC prototype strains. The mutants obtained (042::pFV3 e 2871-1::pFV3) were evaluated in the adherence test with HEp-2 cells and in the biofilm assay in polystyrene plates, demonstrating in both mutants a drastic reduction in the biofilm formation and the inability to adhere to HEp-2 cells. This study demonstrated that, although the role of Shf in the pathogenesis of EAEC is unclear, the shf gene was detected in high prevalence among EAEC strains isolated in Brazil and that Shf was involved in the establishment of the AA pattern as well as in the biofilm formation of typical and atypical EAEC. Moreover, shf may not be exclusively regulated by $\mathrm{AggR}$, since the knockout in this gene present in the atypical EAEC strain (devoid of aggR) abolished the evaluated phenotypes, indicating that shf is expressed in atypical EAEC.

Key words: Diarrhea; Enteroaggregative Escherichia coli; Adherence; Biofilm. 


\section{LISTA DE FIGURAS}

Figura 1 - Capacidade de formação de biofilme em poliestireno apresentada pelas amostras de EAEC típicas e atípicas que albergam o gene shf...... .50

Figura 2 - Padrões de interação das amostras de EAEC 042 (típica) e 2871-1 (atípica) com células HEp-2.

Figura 3 - Pesquisa da presença do gene shf nas amostras de EAEC típica (042) e atípica (2871-1)

Figura 4 - Pesquisa da presença do gene agg $3 A$ nas amostras de EAEC típica (042) e atípica (2871-1).

Figura 5 - Pesquisa da presença do gene agg $3 C$ nas amostras de EAEC típica (042) e atípica (2871-1). 54

Figura 6 - Pesquisa da presença do gene aaiA nas amostras de EAEC típica (042) e atípica (2871-1).

Figura 7 - Pesquisa da presença do gene pilS nas amostras de EAEC típica (042) e atípica (2871-1).

Figura 8 - Pesquisa da presença do gene virk nas amostras de EAEC típica (042) e atípica (2871-1).

Figura 9 - Pesquisa da presença do gene capU nas amostras de EAEC típica (042) e atípica (2871-1). 58

Figura 10 - Curva de crescimento da amostra 2871-1 selvagem e mutante resistente ao ácido nalidíxico (2871-1/Nal).

Figura 11 - Purificação do fragmento shf amplificado por PCR. Eletroforese em gel de agarose $(1,5 \%)$ do produto amplificado na reação de PCR para o gene shf, utilizando os iniciadores shf (F e R) e o DNA da amostra 042.

Figura 12 - Análise do perfil de restrição do plasmídeo pFV2. Eletroforese em gel de agarose $(0,8 \%)$ do DNA plasmidial extraído da amostra JM109(pFV2) antes e após a digestão com a enzima EcoRl.

Figura 13 - Purificação do fragmento shf clonado no plasmídeo pFV2.

Eletroforese em gel de agarose $(0,8 \%)$ do produto de $613 \mathrm{pb}$ da digestão do plasmídeo pFV2 com a enzima EcoRI.

Figura 14 - Confirmação da presença do fragmento shf no plasmídeo pFV3 através de PCR. 
Figura 15 - Padrão de interação das amostras de EAEC 042 (típica), 2871-1 (atípica) e de seus respectivos mutantes 042::pFV3 e 2871-1/Nal::pFV3 com células epiteliais HEp-2.

Figura 16 - Capacidade de formação de biofilme em poliestireno apresentada pelas amostras de EAEC típica (042), atípica (2871-1) e de seus respectivos mutantes 042::pFV3 e 2871-1/Nal::pFV3. 


\section{LISTA DE TABELAS}

Tabela 1 - Características dos plasmídeos empregados neste estudo. .35

Tabela 2 - Seqüência dos iniciadores, ciclos de amplificação e tamanho dos fragmentos amplificados nas reações de PCR deste estudo.

Tabela 3 - Análise das amostras de EAEC shf quanto aos sorogrupos, padrões de adesão, capacidade de formação de biofilme e presença do gene aggR 


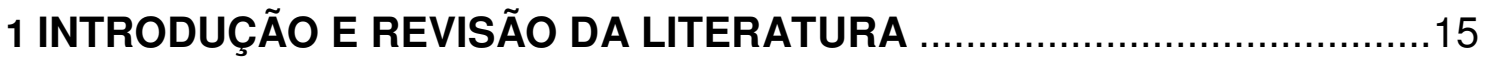

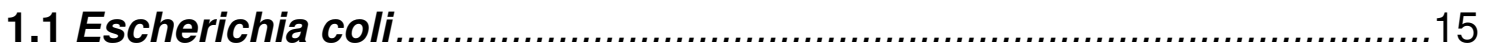

1.2 Escherichia coli diarreiogênicas .................................................15

1.3 Escherichia coli enteroagregativa ...............................................17

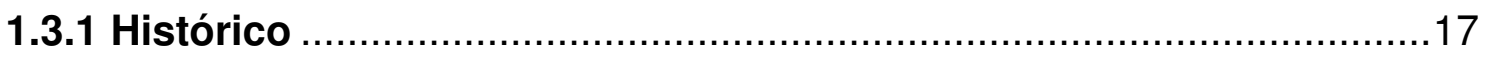

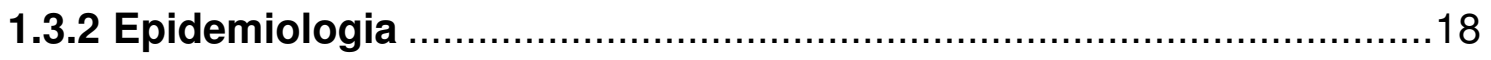

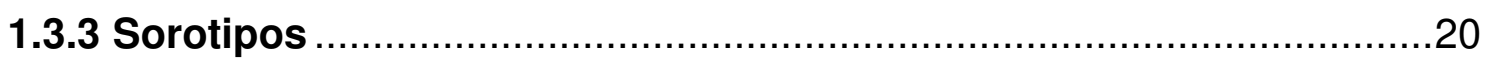

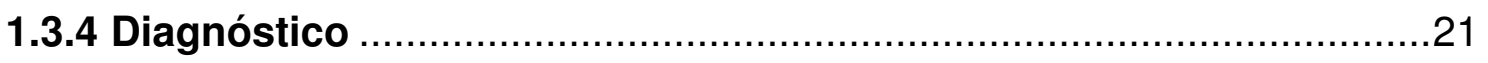

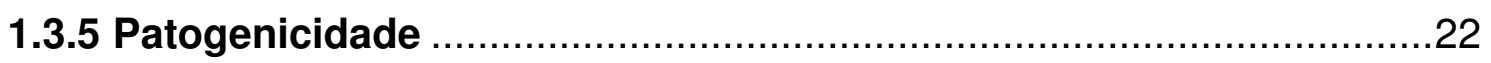

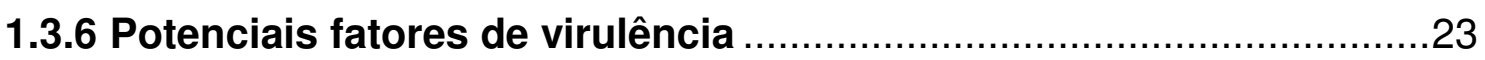

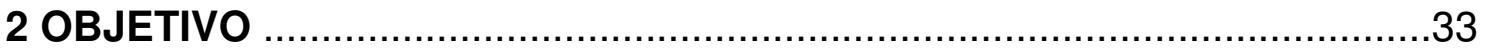

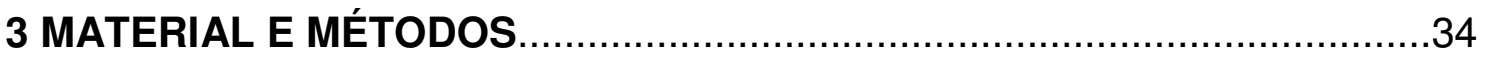

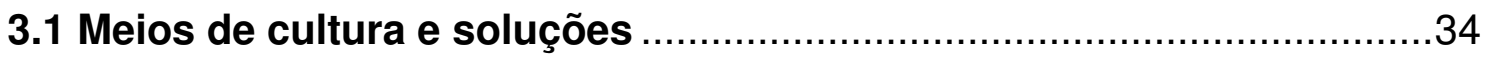

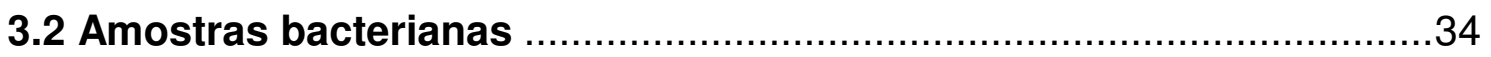

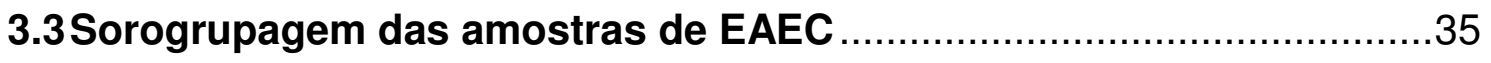

3.4 Pesquisa dos genes de virulência de EAEC ............................................36

3.4.1 Reação em cadeia da polimerase (PCR) ..........................................36

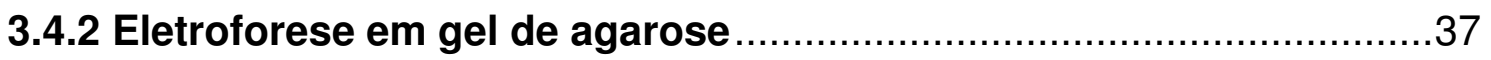

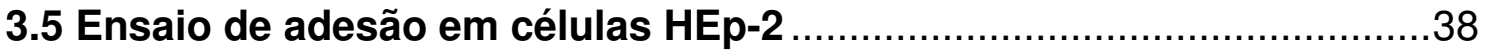

3.5.1 Cultivo das células e preparo das microplacas …............................38

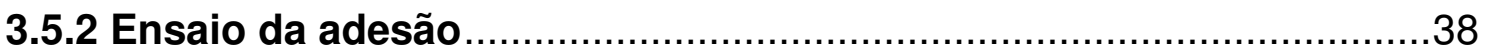

3.6 Avaliação da capacidade de formação de biofilme in vitro..................39

3.7 Mutação do gene shf nas amostras 042 e 2871-1 …..........................40

3.7.1 Obtenção da amostra 2871-1 resistente ao ácido nalidíxico .............40 
3.7.2 Clonagem do gene shf no vetor de clonagem pGEM-T Easy. 41

3.7.2.1 Obtenção do inserto shf 41

3.7.2.2 Ligação do inserto ao vetor pGEM-T Easy .................................42

3.7.2.3 Transformação através de eletroporação .....................................42

3.7.2.4 Seleção do clone contendo o inserto shf no vetor pGEM-T Easy ..43

3.7.3 Subclonagem do inserto shf no vetor pJP5603 …...........................44

3.7.3.1 Ligação do inserto ao vetor pJP5603 …….................................4

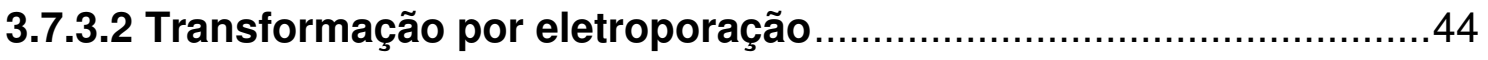

3.7.3.3 Seleção do clone contendo o inserto shf no vetor pJP5603 ..........45

3.7.4 Conjugação da amostra DH5aגpir(pFV3) com as amostras de EAEC

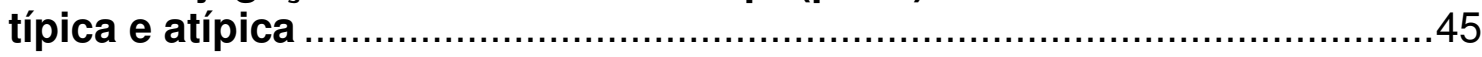

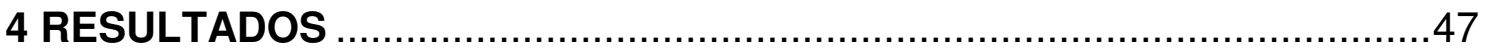

4.1 Prevalência do gene shf em amostras de EAEC isoladas de crianças com diarréia..

4.2 Caracterização fenotípica das amostras de EAEC positivas para o gene shf

4.3 Caracterização fenotípica das amostras de EAEC típica e atípica selecionadas como protótipos

4.4 Caracterização genotípica das amostras de EAEC típica e atípica selecionadas como protótipos

4.5 Determinação do papel da proteína Shf na adesão agregativa e na capacidade de formação de biofilme de EAEC típica e atípica....................59

4.5.1 Mutagênese de shf nas amostras 042 e 2871-1 ................................59

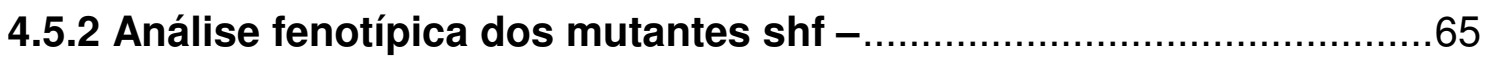

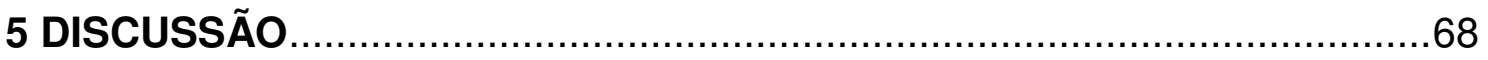

6 CONCLUSÃO

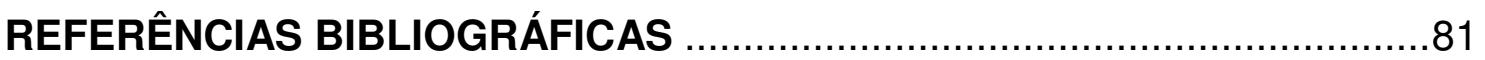




\section{INTRODUÇÃO E REVISÃO DA LITERATURA}

\subsection{Escherichia coli}

A Escherichia coli é um dos microrganismos mais versáteis encontrados na natureza. De ampla distribuição, normalmente coloniza o trato gastrointestinal de humanos e animais, onde faz parte da microbiota e estabelece uma relação mutuamente benéfica com seu hospedeiro. É um dos primeiros gêneros bacterianos a colonizar o trato gastrointestinal humano, já identificada nos primeiros meses de vida, sendo um dos constituintes principais da microbiota intestinal até o fim da vida (GUARNER; MELAGELADA, 2003; NOVERR; HUFFNAGLE, 2004). Foi isolada e identificada primeiramente em 1885 pelo pediatra alemão Theodore Escherich sob o nome de Bacillus coli commune. Em 1919 foi renomeada Escherichia coli em homenagem ao pesquisador que a descreveu (CHEN; FRANKEL, 2005). É uma bactéria Gram-negativa, anaeróbia facultativa, pertencente à família Enterobacteriaceae (BOPP et al., 1999).

Contudo, durante a evolução alguns clones de E. coli adquiriram fatores de virulência que lhes conferiram adaptação a novos nichos e a capacidade de causar um amplo espectro de doenças. As cepas patogênicas de E. coli podem causar infecções intestinais ou extra-intestinais (NATARO; KAPER, 1998). As amostras de E. coli associadas às infecções extraintestinais são conhecidas por ExPEC (RUSSO; JOHNSON, 2000), enquanto as amostras associadas às infecções intestinais, tanto em crianças como em adultos, são conhecidas como E. coli diarreiogênicas (ECD) e são classificadas em seis patótipos (NATARO; KAPER, 1998).

\subsection{E. coli diarreiogênicas}

Inicialmente todas as linhagens diarreiogênicas de E. coli eram denominadas enteropatogênicas, mas ao passo em que foram sendo descobertos os seus mecanismos de patogênese específicos elas foram sendo agrupadas em patótipos (KAPER et al., 2004). 
As amostras de ECD são classificadas em seis patótipos ou categorias, considerando os seus mecanismos de virulência específicos, as síndromes clínicas que causam, os sorotipos $(\mathrm{O}: \mathrm{H})$, os aspectos epidemiológicos e/ou os tipos de interação com linhagens celulares in vitro (NATARO; KAPER, 1998). Esses patótipos são: E. coli enteropatogênica (EPEC), E. coli enterotoxigênica (ETEC), E. coli enteroinvasora (EIEC), E. coli enterohemorrágica (EHEC), E. coli enteroagregativa (EAEC) e E. coli que adere difusamente a células epiteliais (DAEC) (NATARO; KAPER, 1998). Embora essa classificação continue sendo usada pela maioria dos autores, estudos evidenciam que alguns patótipos incluem microrganismos bastante diferentes. Desta forma, as EPEC e EAEC foram subdivididas em típicas e atípicas, e as EHEC passaram a constituir uma subcategoria de STEC, ou E. coli produtora da toxina de Shiga (HARRINGTON et al., 2006; KAPER et al., 2004).

As amostras de EPEC estão associadas à diarréia aguda em crianças principalmente no primeiro ano de vida. Esse patótipo tem a capacidade de causar uma lesão histopatológica no epitélio intestinal, bem como em cultura celular, denominada lesão attaching and effacing $(A / E)$, além de não secretarem a toxina de Shiga (Stx) (TRABULSI et al., 2002). A lesão A/E é caracterizada pela destruição das microvilosidades intestinais, aderência íntima da bactéria à membrana apical da célula epitelial, rearranjo do citoesqueleto e formação de estruturas celulares semelhantes a pedestais, formados pelo acúmulo de actina polimerizada, onde a bactéria permanece aderida (MOON et al., 1983).

ETEC é o patótipo de ECD capaz de produzir uma ou ambas enterotoxinas, denominadas termolábil (LT) e termoestável (ST). Esse patótipo pode aderir à mucosa intestinal através dos seus vários fatores de colonização (LEVINE, 1987). A colonização e a presença das enterotoxinas levam a uma diarréia aquosa tipicamente associada à infecção causada por ETEC, atingindo crianças e adultos. Além disso é fortemente associada como agente de diarréia do viajante (NATARO; KAPER, 1998).

As amostra de EIEC causam diarréia aquosa, colite inflamatória e disenteria em humanos. São bioquimica, genetica e patogenicamente relacionadas à Shigella spp.. O mecanismo de patogênese das EIEC consiste 
da invasão da mucosa intestinal, seguido de fagocitose e lise do vacúolo endocítico, multiplicação intracelular, movimentação no citoplasma e passagem para as células adjacentes (PARSOT, 2005).

STEC foi primeiramente identificada nos Estados Unidos em 1982, como agente de um surto de diarréia sanguinolenta e da síndrome hemolítica urêmica (SHU) (RILEY et al., 1983). STEC é classificada como um patógeno zoonótico emergente que pode causar gastroenterite e colite hemorrágica, podendo ainda produzir uma severa complicação renal, a SHU, devido à translocação da toxina Stx através do intestino (FRANKEL et al., 1998). As STEC possuem ainda uma subcategoria, denominada EHEC, sendo que a diferença entre essas subcategorias se dá pela capacidade das EHEC de produzir a lesão A/E, semelhante às EPEC (NATARO; KAPER, 1998).

DAEC foi assim denominada devido ao padrão de adesão difusa (AD) que as amostras deste patótipo apresentam em ensaios de adesão em células epiteliais cultivadas, onde as bactérias aderem-se de forma difusa sobre toda a superfície celular (NATARO et al., 1987). A associação de DAEC com diarréia é controversa, uma vez que vários estudos epidemiológicos não associam esse patótipo à doença diarréica (GOMES et al., 1998; RODRIGUES et al., 2002; SCALETSKY et al., 2002a; GIRÓN et al., 1991).

EAEC é definida como o patótipo de $E$. coli que adere a células epiteliais cultivadas no padrão denominado agregativo (NATARO et al., 1987). Desde a sua descrição em 1987, EAEC tem sido reconhecida cada vez mais como agente de diarréia aguda e persistente em países em desenvolvimento e desenvolvidos e é, atualmente, considerado um enteropatógeno emergente (KAPER et al., 2004; HARRINGTON et al., 2006).

\subsection{E. coli enteroagregativa (EAEC)}

\subsubsection{Histórico}

Cravioto et al. (1979) reportaram que a maioria das EPEC apresentavam a capacidade de aderir às células epiteliais cultivadas da linhagem HEp-2, e que o fenótipo aderente poderia ser utilizado para diferenciação de EPEC. Subseqüentemente, outros estudos demonstraram 
que muitas E. coli não classificadas como EPEC, também aderiam à camada semi-confluente de cultura de células, porém, em um padrão distinto do apresentado pela categoria de EPEC. Enquanto a adesão de EPEC era do tipo localizada, ou seja, as bactérias se apresentavam aderidas em pontos específicos da superfície da célula epitelial, em grupamentos compactos de bactérias, as amostras não classificadas como EPEC apresentavam um padrão difuso de aderência sobre a superfície celular (SCALETSKY et al., 1984; NATARO et al., 1985). Posteriormente esse padrão inicialmente chamado de difuso foi reclassificado em "padrão difuso propriamente dito" e "padrão agregativo" (NATARO et al., 1987).

O termo adesão agregativa (AA) foi estabelecido por Nataro et al. (1987), para definir o padrão de adesão em células HEp-2 apresentado por amostras de $E$. coli isoladas em um estudo epidemiológico envolvendo crianças com diarréia no Chile. No padrão AA as bactérias aderem-se umas as outras, à superfície das células HEp-2, e também à superfície da lamínula na ausência de células, numa configuração que lembra tijolos empilhados, formando agregados heterogêneos (NATARO et al., 1987).

De modo semelhante ao que ocorreu com as EPEC, Sarantuya et al. (2004) propuseram a classificação de amostras de EAEC nos grupos típica e atípica. Enquanto as EPEC são classificadas nesses dois grupos levando-se em conta a presença ou ausência do plasmídeo EPEC adherence factor (pEAF) (KAPER, 1996), no patótipo EAEC essa classificação se baseia na presença ou não do gene aggR, o qual codifica uma proteína reguladora global dos genes de virulência de EAEC e está localizado no plasmídeo de virulência de EAEC (NATARO et al., 1994; HARRINGTON et al., 2006).

\subsubsection{Epidemiologia}

EAEC foi inicialmente descrita em associação com diarréia aguda em crianças (NATARO et al., 1987). Em seguida, inúmeros estudos epidemiológicos foram realizados em países em desenvolvimento avaliando EAEC como agente associado à diarréia aguda. Vários desses estudos encontraram essa associação (BOUZARI et al., 1994; GONZÁLEZ et al., 1997; NATARO et al., 1987; PAUL et al.,1994), mas em alguns tal associação não foi 
encontrada (BHATNAGAR et al., 1993; CRAVIOTO et al., 1991; GOMES et al., 1989; GOMES et al., 1998).

Essa controvérsia pode estar associada às diferenças entre esses estudos no que se refere à faixa etária dos grupos estudados e aos métodos de detecção de EAEC. Nos últimos anos a associação entre EAEC e diarréia aguda na infância tem sido sempre positiva, tanto em países em desenvolvimento (BUERIS et al., 2007; REGUA-MANGIA et al., 2004; NGUYEN et al., 2005; RODRIGUES et al., 2002; SCALETSKY et al., 2002b; OKEKE et al., 2000), como desenvolvidos (COHEN et al., 2005; NATARO et al., 2006; ROBINS-BROWNE et al., 2004). Nos EUA, EAEC é um dos patógenos mais comumente identificados em casos de diarréia (FLORES; OKHUYSEN, 2009).

Outros estudos epidemiológicos realizados também em países em desenvolvimento associaram fortemente EAEC à diarréia persistente, ou seja, com duração maior que 14 dias (BHAN et al., 1989; CRAVIOTO et al., 1991; FANG et al., 1995). No Brasil estudos demonstraram a associação entre EAEC e a diarréia persistente na cidade de Fortaleza, onde EAEC está implicada em mais de 68\% dos casos (PINTO et al., 1983; LIMA et al., 1992; FANG et al., 1995). Nessa mesma cidade, Steiner et al. (1998) demonstraram a relação entre colonização por EAEC, independente da sintomatologia de diarréia, e o déficit de desenvolvimento (peso/altura) de crianças de baixo nível sócio-econômico.

Vários estudos sobre a etiologia da diarréia do viajante, que afeta indivíduos residentes de países desenvolvidos que visitam países em desenvolvimento, apontam uma alta prevalência de EAEC (ADACHI et al., 2001; JIANG et al., 2002; MOHAMED et al., 2007).

Há também relatos na literatura da associação de EAEC como agente de diarréia aguda e persistente em pacientes imunocomprometidos, como os portadores do vírus da imunodeficiência humana (DURRER et al., 2000; GERMANI et al., 1998; KELLY et al., 2003; PABST et al., 2003; SAMIE et al., 2008).

Surtos de diarréia causados por EAEC, associados à ingestão de alimentos ou água contaminados, foram relatados em países desenvolvidos 
(HARADA et al., 2007; ITOH et al., 1997; SMITH et al., 1994; SMITH et al., 1997).

Esses diversos estudos demonstrando a associação epidemiológica entre EAEC e diarréia aguda, persistente e diarréia do viajante, além do relato de surtos de diarréia causados por EAEC, apontam que este patótipo deve ser considerado emergente (NATARO; KAPER, 1998), inclusive no Brasil onde em estudos recentes sobre a etiologia da diarréia aguda tem sido encontrado como o agente bacteriano mais freqüente (BUERIS et al., 2007; REGUAMANGIA et al., 2004; RODRIGUES et al., 2002; SCALETSKY et al., 2002b).

\subsubsection{Sorotipos}

A E. coli apresenta antígenos de superfície que possibilitam a sua classificação em sorogrupos (tipagem do antígeno somático ou O) e sorotipos (tipagem dos antígenos somático e flagelar ou H) (EWING, 1986). A sorotipagem de amostras de $E$. coli é extremamente útil em estudos epidemiológicos e no diagnóstico de EPEC típica e EIEC. Quando aplicada em EAEC a sorotipagem evidencia uma grande diversidade de sorotipos (CZECZULIN et al., 1999; JENKINS et al., 2006a; KNUTTON et al., 1992; PIVA et al., 2003; UBER et al., 2006; VIAL et al., 1988; ZAMBONI et al., 2004), sem a prevalência de nenhum.

Nataro e Kaper (1998) relataram os seguintes sorotipos de EAEC como os mais freqüentes em uma compilação de vários relatos: O3:H2, O15:H18, O44:H18, O86:NM, O77:H18, O111:H12, O111:H21 e O127:H2.

A existência de um grande número de amostras não tipáveis quanto ao antígeno $\mathrm{O}$ ou rugosas tem sido relatada nesta categoria (KESKIMÄKI et al., 2001; VIAL et al., 1988; UBER et al., 2006). Um grande número de cepas de EAEC são imóveis ou não tipáveis quanto ao antígeno $\mathrm{H}$ (KESKIMÄKI et al., 2001; KNUTTON et al., 1992; VIAL et al., 1988; UBER et al., 2006), dificultando a análise da relação entre sorotipo e outras características da amostra. Desta forma, a sorotipagem não representa uma ferramenta útil para o diagnóstico de EAEC. 


\subsubsection{Diagnóstico}

O padrão AA demonstrado no teste de adesão em células HeLa ou HEp-2 é usado como diagnóstico padrão (gold standard) para a classificação de EAEC (NATARO; KAPER; 1998), uma vez que ainda não foi encontrado um determinante genético comum para todas as amostra deste patótipo (HARRINGTON et al., 2006).

Já foram encontradas variações do padrão $A A$ originalmente descrito, as quais incluem a adesão das bactérias no padrão $A A$ preferencialmente à lamínula (AAcs) ou preferencialmente à superfície celular (AAcel) (KNUTTON et al,1992; PAUL, et al., 1994; GIOPPO, et al., 2000; SUZART et al., 2001).

O fenótipo de agregação bacteriana também pode ser evidenciado pela formação de uma película na superfície da cultura, quando amostras de EAEC são cultivadas em caldo Müller-Hinton (ALBERT et al., 1993), bem como pela capacidade dessas bactérias em formar biofilmes sobre superfícies de poliestireno ou vidro, importante característica associada à virulência de EAEC (MOHAMED et al., 2007; SHEIKH et al., 2001; WAKIMOTO et al., 2004). Foi proposto por Wakimoto et al. (2004) um teste quantitativo de formação de biofilme utilizando placas de poliestireno para o diagnóstico de EAEC.

Baudry et al. (1990) desenvolveram uma sonda genética sensível e específica para o diagnóstico de EAEC, inicialmente denominada CVD432, a qual consistia em um fragmento críptico de $1 \mathrm{~kb}$ do plasmídeo de virulência presente na amostra de EAEC 17-2 (sorotipo O3:H2). Desta forma, a sonda CVD432 detecta a presença do plasmídeo associado à virulência em EAEC. Posteriormente, essa sonda passou a ser também denominada sonda AA ou sonda EAEC, e foi amplamente empregada em diversos estudos epidemiológicos, demonstrando que a sua especificidade e sensibilidade variam de acordo com o grupo de amostras estudadas (FANG et al., 1995; FARUQUE et al., 1992; GIOPPO et al., 2000; GOMES et al., 1998; OKEKE et al., 2000; PAUL et al., 1994).

Em 1995, Schmidt et al., seqüenciaram o fragmento sonda CVD432 e a partir dessa seqüência desenharam um par de iniciadores para a detecção de EAEC através de uma reação em cadeia da polimerase (PCR). 
Recentemente, Nishi et al. (2003) evidenciaram que o fragmento sonda CVD432 na verdade corresponde ao gene aat $A$, o qual faz parte de um cluster de cinco genes (aatPABCD) que codificam as proteínas do sistema do tipo $A B C$ de secreção. Desta forma, a sonda CVD432 passou a ser corretamente denominada de aatA.

Alguns autores propuseram o diagnóstico para EAEC baseado na técnica de PCR multiplex, empregando a detecção simultânea de marcadores plasmidiais (BOUZARI et al., 2005; CERNA et al., 2003; RÜTTLER et al., 2006) ou plasmidiais e cromossômicos (JENKINS et al., 2006b) específicos para EAEC. Essa técnica foi avaliada como específica e sensível para a caracterização de amostras de EAEC isoladas de fezes (CORDEIRO et al., 2008).

Um estudo recente demonstrou que o DNA de EAEC pode ser recuperado para realização da técnica de PCR no diagnóstico de EAEC, a partir de cartões de papel de filtro empregados na coleta de fezes para a detecção de sangue oculto (GRIMES et al., 2008).

Conforme mencionado anteriormente, a sorotipagem não representa uma ferramenta útil no diagnóstico de EAEC. Desta maneira, apesar das tentativas de se criarem novas técnicas fenotípicas e moleculares sensíveis e específicas para o diagnóstico de EAEC, o ensaio de detecção do padrão de adesão agregativa em células HEp-2 ou HeLa continua sendo o teste padrão para a identificação desse patótipo.

\subsubsection{Patogenicidade}

Vários potenciais fatores de virulência foram descritos em EAEC, mas a patogênese da diarréia causada por esse patótipo ainda não foi esclarecida (HARRINGTON et al., 2006). EAEC intensifica a secreção de muco na mucosa intestinal formando um denso biofilme no local. O papel da produção de muco na patogênese de EAEC não está claro, mas a formação de biofilme pode estar envolvida com o caráter persistente da colonização e da diarréia (NATARO; KAPER, 1998).

Acredita-se que a diarréia causada por EAEC se inicia com a adesão agregativa nos tecidos do íleo e cólon por um número variado de adesinas, 
seguida pela secreção de uma ou mais enterotoxinas (HARRINGTON et al., 2006).

Nataro et al. (1998) propuseram um modelo de três estágios para a patogênese de EAEC. O primeiro estágio envolve a adesão inicial à mucosa intestinal e à monocamada de muco, sendo que essa adesão é mediada pelas fímbrias AAF. O segundo estágio compreende a indução de uma maior produção de muco, levando à formação de biofilme nessa camada mucóide. Essa camada de biofilme e muco pode levar a colonização persistente e má absorção de nutrientes. E finalmente, o terceiro estágio, sugerido após observações histopatológicas e evidências moleculares, que incluem a produção de toxinas e o desencadeamento de um processo inflamatório, o qual resulta em danos à mucosa e secreção intestinal. $O$ hospedeiro que sofre de subnutrição pode ser incapaz de reparar os danos e tende a desenvolver a síndrome da diarréia persistente.

As manifestações clínicas resultantes da infecção por EAEC são a diarréia aguda e persistente (HARRINGTON et al., 2006). A diarréia pode ser aquosa ou mucóide, com poucos relatos de febre ou vômito (BHAN et al., 1994; PAUL et al., 1994).

A patogenicidade de EAEC tem sido atribuída a fatores particulares que não estão uniformemente distribuídos entre as amostras de EAEC isoladas ao redor do mundo (NATARO, KAPER, 1998; SPENCER et al., 1999; OKEKE et al., 2000; SARANTUYA et al., 2004; JENKINS et al., 2006a; UBER et al., 2006).

\subsubsection{Potenciais fatores de virulência}

Além da expressão de adesinas e toxinas, vários outros fatores de virulência têm sido descritos em EAEC, codificados por genes localizados tanto em plasmídeos quanto no cromossomo de amostras consideradas protótipo (WEINTRAUB, 2007).

Grande parte dos potenciais fatores de virulência descritos em EAEC foi caracterizada na amostra protótipo de EAEC 042. Essa amostra pertencente ao sorotipo $\mathrm{O} 44: \mathrm{H} 18$, foi isolada de um caso de diarréia no Peru e foi capaz de causar diarréia em voluntários humanos (NATARO et al., 1985). 
Nessa amostra, a maioria dos genes que codificam esses fatores estão localizados no plasmídeo de virulência pAA2 ( 100 kb) presente nesta amostra (CZECZULIN et al., 1999).

Embora uma diversidade de adesinas, toxinas e proteínas envolvidas em algum processo de virulência tenham sido descritas em EAEC, tem sido amplamente demonstrado que a prevalência dos genes que codificam esses marcadores é bastante variável com relação à origem geográfica das amostras e nenhum deles foi encontrado em todas as amostras de EAEC (BOUZARI et al., 2005; CZECZULIN et al., 1999; ELIAS et al., 2002; GIOPPO et al., 2000; JENKINS et al., 2006a; MOHAMED et al., 2007; OKEKE et al., 2000; PIVA et al., 2003; SUZART et al., 2001; ZAMBONI et al., 2004).

Diversas adesinas fimbriais e afimbriais já foram descritas como responsáveis pelo estabelecimento do padrão AA em amostras de EAEC. Entretanto, a prevalência dos genes que codificam essas adesinas é geralmente baixa, demonstrando a diversidade de estruturas de superfície associadas à adesão agregativa (BERNIER et al., 2002; BOISEN et al., 2008; CZECZULIN et al., 1997; DEBROY et al., 1995; DUDLEY et al., 2006a; MONTEIRO-NETO et al., 2003; NATARO et al., 1992; WAl et al., 1996).

A presença de fímbrias apresentando diferentes morfologias tem sido descrita em diversas amostras de EAEC, através de estudos de microscopia eletrônica de transmissão (VIAL et al., 1988; KNUTTON et al., 1992). Entretanto, apenas as estruturas fimbriais denominadas Aggregative Adherence Factor (AAF) I, II e III foram geneticamente caracterizadas (NATARO et al., 1992, ELIAS et al., 1999; BERNIER et al., 2002). As fímbrias AAF/I, II e III são codificadas por plasmídeos que possuem em torno de 100 kb, e todas elas são requeridas para a expressão do fenótipo agregativo nas respectivas amostras protótipo.

A fímbria $A A F / l$ é flexível e formada por feixes frouxos e medeia o padrão AA em células epiteliais (NATARO et al., 1992). Os genes que codificam AAF/I na amostra protótipo 17-2 estão localizados no plasmídeo pAA1 e são separados em duas regiões (designadas região 1 e 2) por um segmento de DNA de aproximadamente $9 \mathrm{~kb}$ (NATARO et al., 1992; NATARO et al., 1994; SAVARINO et al.,1994). A região 1 contém o cluster de quatro genes, aggDCBA, os quais codificam, a pilina da fímbria (AggA), uma proteína 
críptica (AggB), a chaperonina (AggD), e o usher (AggC). A região 2 codifica um regulador homólogo a classe de proteínas reguladoras da transcrição da família AraC, denominado AggR, ativador transcricional necessário para a expressão dessa fímbria (NATARO et al., 1994).

A fímbria $A A F / l l$ foi descrita na amostra protótipo 042 e é genética e morfologicamente distinta de AAF/l. Apresenta estrutura em forma de feixes semi-rígidos e medeia o padrão AA em células epiteliais (CZECZULIN et al.,1997).

Os genes responsáveis pela biogênese de AAF/ll também estão separados em duas regiões, porém sua organização é única, ou seja, os genes que codificam a chaperonina (aafD), a pilina (aafA), e o ativador transcricional $(a g g R)$ estão presentes na região 1, enquanto os genes que codificam o usher (aafC), e a invasina (aafB) estão localizados na região 2 (ELIAS et al., 1999).

A terceira fímbria AAF foi identificada na amostra de EAEC 55989 por Bernier et al. (2002). AAF/III também está envolvida com a agregação das bactérias e sua adesão agregativa a células epiteliais, e sua biogênese é codificada pelo operon agg-3, o qual é bastante semelhante ao operon afa das adesinas AFA de E. coli uropatogênicas (SERVIN, 2005). Diferentemente de $A A F / /$ e II, as quais formam feixes frouxos, AAF/III aparece em filamentos

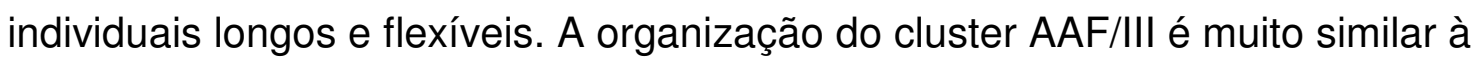
organização da AAF/l, constituído pelos genes agg-3A, agg-3B, agg-3C, agg$3 D$. Em uma região localizada $5 \mathrm{~kb}$ à jusante do gene aggA, se localiza um gene que possui homologia com o gene aggR (BERNIER et al., 2002).

Adesinas não fimbriais, ou proteínas de membrana externa associadas ao padrão $A A$, têm sido evidenciadas em diversas amostras de EAEC pertencentes a distintos sorotipos (CHART et al., 1995; DEBROY et al., 1995; WAl et al., 1996; MONTEIRO-NETO et al., 1998, 2003). Debroy et al. (1995) e Wai et al. (1996), mostraram a presença de proteínas de membrana externa de 30 e $38 \mathrm{kDa}$, respectivamente, relacionadas ao fenótipo AA em amostras de EAEC. Monteiro-Neto et al. (2003) evidenciaram a participação de uma proteína de membrana externa de $58 \mathrm{kDa}$, denominada aggregative protein 58 (Ap58) na adesão agregativa em amostras de E. coli do sorotipo O111:H12. O 
gene que codifica essa adesina (ap58) foi localizado no cromossomo da amostra protótipo (MONTEIRO-NETO et al., 2003).

Foi demonstrado na amostra de EAEC atípica C1096 (sorotipo O4:HNT) isolada na Sérvia, que a adesão agregativa em células epiteliais cultivadas e superfícies abióticas era mediada por um pili do tipo IV, codificado por genes presentes em um plasmídeo do grupo de incompatibilidade Incl1. O gene pilS codifica a pilina correspondente à subunidade principal do pili tipo IV descrito na amostra C1096. A expressão do pili tipo IV é necessária, mas não completamente responsável pela adesão agregativa (COBELJIC et al., 1996; DUDLEY et al., 2006a).

Recentemente, foi descrita uma nova adesina responsável pelo padrão AA em amostras de EAEC isoladas na Dinamarca, denominada Hda (BOISEN et al., 2008). O gene $h d a A$, que codifica a pilina $\mathrm{HdaA}$, é responsável pelo fenótipo agregativo em amostras de EAEC que não apresentam as adesinas fimbriais AAF. Esse gene parece ser também regulado por AggR (BOISEN et al., 2008). A estrutura morfológica da adesina Hda não foi demonstrada por esses autores, embora o gene $h d a A$ tenha sido previamente descrito no GenBank como codificando uma pilina hipotética relacionada à família $\mathrm{Dr}$ de adesinas (BOISEN et al., 2008).

EAEC é considerado um enteropatógeno não invasor, entretanto, alguns pesquisadores têm sugerido que EAEC pode ser capaz de invadir, ou pelo menos, um grupo de EAEC pode apresentar o fenótipo invasivo (ABE et al., 2001; BENJAMIN et al., 1995; HARADA et al., 2007; KOO et al., 2008; PEREIRA et al., 2008).

Benjamin et al. (1995), demonstraram que amostras de EAEC eram internalizadas por células HeLa e que essa internalização era mediada por componentes do citoesqueleto celular. Abe et al. (2001), utilizando a amostra de EAEC 236 (O111:H12), demonstraram um fenótipo de invasão em células T84 e biópsia de mucosa de cólon humano. Esta observação, associada ao fato de que crianças com diarréia causada por EAEC no México apresentavam sangue nas fezes (CRAVIOTO et al., 1991), sugere que essa capacidade de invasão possa ser uma importante propriedade de virulência de algumas amostras da categoria. 
Diversos autores descreveram a capacidade de amostras de EAEC, isoladas de casos de diarréia, em causar efeitos tóxicos em células epiteliais humanas cultivadas e também em mucosas (GOMES et al., 1995; HENDERSON et al., 1999; HICKS et al., 1996; TZIPORI et al., 1992; VIAL et al., 1988; NAVARRO-GARCIA et al., 1999).

Savarino et al. (1991) identificaram em amostras de EAEC uma enterotoxina termoestável denominada $E$. coli heat-stable enterotoxin 1 (EAST1). Essa enterotoxina apresenta homologia significante com o domínio enterotóxico da toxina ST de ETEC, sendo capaz de induzir um aumento da concentração de cGMP intracelular (SAVARINO et al., 1993). O gene que codifica EAST1 (astA) está localizado no plasmídeo pAA2 da amostra 042 (CZECZULIN et al., 1999). O papel de EAST1 na patogênese é questionável uma vez que a sua presença foi também detectada em amostras de E. coli não patogênicas (SAVARINO et al., 1996). Foi descrita a ocorrência de pelo menos duas variantes naturais dessa enterotoxina: EAST-1 da amostra 17-2 e EAST-1 da amostra 042. Essa diferença reside na substituição de um aminoácido e confere maior capacidade toxigênica à toxina EAST-1 da amostra 042 (VEILLEUX et al., 2008).

Navarro-Garcia et al. (1998) ao analisarem sobrenadantes de culturas de amostras de EAEC causadoras de um surto de diarréia no México, descreveram duas proteínas secretadas de 108 e $116 \mathrm{kDa}$ com atividades citotóxicas. Ambas as proteínas foram caracterizadas como autotransportadoras e são clivadas antes de tornarem-se funcionais. Essas proteínas contêm o motivo de protease característico de todas as serinoproteases autotransportadoras da família Enterobacteriaceae (HENDERSON et al., 1998).

Eslava et al. (1998) identificaram a enterotoxina de 108 kDa, capaz de causar acúmulo de fluído e lesões necróticas e hemorrágicas em alça ligada de rato, a qual foi denominada plamid encoded toxin (Pet). O gene que codifica essa toxina (pet) também foi localizado no plasmídeo pAA2 da amostra 042 (ELIAS et al., 1999).

A outra proteína de $116 \mathrm{kDa}$ foi identificada por Henderson et al. (1999) e denominada protein involved in intestinal colonization (Pic). Essa toxina apresenta atividade mucinolítica, de hemaglutinação e confere à 
bactéria a capacidade de resistir à atividade bactericida do soro. Diferentemente de pet, o gene que codifica a proteína Pic (pic) está localizado no cromossomo da amostra protótipo 042 e a sua presença também foi detectada em Shigella flexneri 2a (HENDERSON et al., 1999).

A toxina denominada ShET1 (Shigella enterotoxin 1) é codificada na fita anti-senso em relação ao gene pic. Os genes setA e setB codificam a holotoxina predita do tipo A1:B5 (FASANO et al., 1995), que causa acúmulo de fluido em modelo in vivo de alça intestinal ligada de coelhos (HARRINGTON et al., 2006). Enquanto ShET1 é uma enterotoxina, Pic possui atividade mucinolítica a de hemaglutinina (HENDERSON et al. , 1999). Esse locus não é exclusivo de EAEC, visto que os genes pic/setBA são encontrados também em Shigella flexneri 2a (FASANO et al., 1995) e em E. coli uropatogênica (HEIMER et al., 2004).

Além dos genes pic e setAB, que codificam as toxinas Pic e ShET1, respectivamente, no cromossomo da amostra 042 foi localizado o gene irp-2 que codifica a proteína Irp2.

O gene que codifica Irp2 (iron-repressible high-molecular weight protein 2) está presente em uma ilha de patogenicidade do cromossomo de Yersinia enterocolitica, onde codifica uma proteína envolvida na biossíntese de um sideróforo (yersiniabactina), responsável pela captação de ferro neste gênero (SCHUBERT et al., 1998). Esses mesmos autores relataram a presença do gene irp-2 no cromossomo de 93\% das amostras de EAEC estudadas, sendo raramente encontrada em EPEC, EIEC, ETEC e ausente em EHEC, Shigella spp. e Salmonella spp.

A análise do alinhamento da seqüência da amostra 042, revelou que pic/setBA está localizado na ilha de patogenicidade (PAI) de 117 kb inserida no locus do tRNA pheU (DUDLEY et al., 2006b). Al Hasani et al (2001), determinaram que o locus pic/setBA está na PAI denominada she em Shigella flexneri YSH6000T, inserida ao lado do gene tRNA pheV. O elemento móvel IS que flanqueia esse gene em EAEC difere da seqüência de inserção que o flanqueia na outra espécie, sugerindo que a aquisição foi distinta para essas duas espécies.

Essa PAl da amostra 042 localizada em pheU contém um grupo de genes regulados por AggR, os quais foram denominados aai (AggR-activated 
island) (DUDLEY et al., 2006b). Esse operon codifica genes envolvidos na secreção de pelo menos uma proteína e parece fazer parte do aparato de secreção da proteína AaiC. Outros autores têm descrito a presença de genes similares ao operon aai em outros organismos Gram-negativos patogênicos e bactérias simbiontes (FOLKESSON et al., 2002; RAO et al., 2004). Mais recentemente, o termo sistema de secreção do tipo 6 foi sugerido para a secreção de AaiC mediada pelo operon aai (PUKATZKI et al., 2006). A contribuição dos genes aaiA para a patogênese de EAEC é desconhecida, porém esses genes não parecem ter uma função na aderência a superfícies ou a células do epitélio intestinal, como descrito previamente por genes regulados por AggR (DUDLEY et al., 2006b).

Czeczulin et al. (1999) identificaram diversos genes cromossômicos e plasmidiais na amostra protótipo 042 associados à virulência de EAEC. Dentre os plasmidiais, além dos genes da biogênese de AAF/II (aafA, aafC, aafD e aggR), das toxinas Pet (pet) e EAST1 (astA) e da seqüência correspondente ao fragmento sonda CVD432 (aatA), foram também identificados os genes denominados aspU/aap, shf, capU e virK.

Uma proteína de $10 \mathrm{kDa}$, a qual foi imunogênica em estudos com voluntários humanos, foi descrita por Czeczulin et al. (1999) como sendo codificada pelo gene aspU localizado no plasmídeo pAA2 da amostra 042. Sheikh et al. (2002) descreveram que aspU está sob controle do ativador transcricional aggR e alteraram a nomenclatura deste gene para aap (antiaggregation protein). O produto de aap, denominado dispersina, possui uma seqüência sinal e é secretado para o meio extracelular, onde permanece ligado ao lipopolissacarídeo da bactéria, neutralizando a carga negativa da superfície externa e permitindo a projeção das fímbrias (VELARDE et al., 2007). Mutantes nesse gene possuem autoagregação muito intensa, indicando que a dispersina atua diminuindo a autoagregação e permitindo a dispersão da mesma na mucosa intestinal. A translocação da dispersina através da membrana externa está relacionada ao sistema de transporte do tipo $A B C$ do qual aatA faz parte (NISHI et al., 2003).

O seqüenciamento do plasmídeo pAA2 da amostra 042 revelou entre os genes aafC e aat $A$ a presença de um grupo formado por três genes denominados shf, capU e virk (CZECZULIN et al.,1999), o qual apresentou 
alta similaridade com o mesmo grupo localizado no plasmídeo de virulência de Shigella flexneri (FUJIYAMA et al., 2008). Esse grupo de genes foi denominado cap cluster (CZECZULIN et al.,1999; RAJAKUMAR et al., 1996).

O gene capU codifica uma proteína que apresenta $50 \%$ de identidade com uma proteína relacionada à biossíntese de lipopolissacarídeo de E. coli O157:H7 (CZECZULIN et al., 1999). O gene virK foi sugerido como sendo um regulador pós-transcricional de virG, ambos localizados no plasmídeo de virulência de Shigella flexneri (NAKATA et al., 1992).

O gene plasmidial shf, assim denominado por apresentar homologia com dois genes descritos em Shigella flexneri 2a (shf1 e shf2), contém $842 \mathrm{pb}$ e codifica uma proteína predita de 280 aminoácidos, com massa de $32,8 \mathrm{kDa}$, de função não estabelecida (CZECZULIN et al., 1999). Homólogos de shf foram encontrados nos plasmídeos p0157 de EHEC O157:H7 e pCoo de ETEC (CZECZULIN et al.,1999).

O gene shf foi encontrado em alta prevalência em amostras de EAEC isoladas em nosso meio (ELIAS et al., 2002; PIVA et al., 2003; ZAMBONI et al., 2004) e no exterior (CZECZULIN et al., 1999; OKEKE et al., 2000; JENKINS et al., 2006a). Entretanto poucos estudos avaliaram essa prevalência classificando as amostras de EAEC em típicas e atípicas.

A proteína predita codificada por shf apresenta $25 \%$ de similaridade com a proteína IcaB de Staphylococcus epidermidis, a qual possui relação na formação de biofilme nessa espécie, participando da biossíntese de um exopolissacarídeo responsável pela adesão célula-célula e pluriestratificação das bactérias no biofilme (HEILMANN et al., 1996). O papel de S. epidermidis como patógeno humano tem sido demonstrado nos últimos anos principalmente pela associação com infecções persistentes associadas à formação de biofilme em cateteres (SPEZIALE et al., 2008).

A capacidade de EAEC em formar biofilme in vivo foi descrita em cultura de biópsia de cólon humano e sugere uma relação com a persistência da diarréia (SHEIKH et al., 2001). A participação da fímbria AAF/II e das proteínas Fis e YafK na formação desse biofilme de EAEC foi descrita por Sheikh et al. (2001), utilizando a amostra protótipo 042 cultivada em meio de cultura celular rico em glicose. O gene cromossômico fis codifica a proteína Fis envolvida na transcrição fase de crescimento dependente. YafK é uma 
proteína hipotética de $28 \mathrm{kDa}$, codificada pelo gene yafK e requerida para a expressão de AAF/ll a nível pós-transcricional (SHEIKH et al., 2001). O envolvimento da fímbria tipo I no fenótipo de formação de biofilme em EAEC foi evidenciado por Moreira et al. (2003).

Alguns microrganismos ao invés de aderir individualmente possuem a capacidade de adesão formando aglomerados bacterianos. Portanto, 0 biofilme nada mais é que camadas múltiplas de bactérias, em associação ou não com outros microrganismos aderidos a diferentes tipos de superfície, como plástico, vidro, metal, entre outros materiais (DONLAN, 2002). Os biofilmes são também comunidades bacterianas aderidas a superfícies vivas, como por exemplo os biofilmes que formam a placa bacteriana. Os biofilmes podem ser formados por uma única espécie, bem como por interações entre diversas espécies bacterianas (WHITTAKER et al., 1996).

A importância médica da formação dos biofilmes bacterianos reside no fato destes serem usualmente relacionados a infecções persistentes, como nos casos de infecções de implantes cirúrgicos e em cateteres, sendo uma causa comum de infecções hospitalares (DONLAN; COSTERTON, 2002). A dificuldade de tratamento adequado para infecções persistentes causadas a partir da formação de biofilmes, está diretamente relacionada à estrutura compacta dos mesmos, onde substâncias tóxicas às células bacterianas, como por exemplo os antibióticos, enfrentam dificuldades para penetrar no biofilme bacteriano (COSTERTON et al., 1999; STEWART; COSTERTON, 2001).

A produção de uma mistura extracelular de polímeros de açúcar denominados exopolissacarídeos, é característico e crítico para a formação de biofilmes bacterianos, sendo o principal componente da sua matriz (WATNICK, KOLTER, 2000). Estudos demonstraram que a proteína IcaB de $S$. epidermidis é responsável pela desacetilação da molécula poli-N-acetilglucosamina, formando uma molécula exopolissacarídica presente em muitos microrganismos, e que participa da formação do biofilme (VUONG et al., 2004).

Embora a função da proteína Shf não seja conhecida, a sua homologia com IcaB sugere uma possível participação na formação de biofilme e conseqüentemente na adesão agregativa de EAEC. Desta forma, a investigação da participação de Shf nesses fenótipos em amostras de EAEC 
típica e atípica é justificável. Além disso, como a investigação da prevalência de shf em coleções de EAEC classificadas como típica ou atípica é escassa, essa pesquisa em amostras isoladas de casos de diarréia em nosso país é importante e auxiliará na compreensão dos mecanismos de virulência de EAEC típica e atípica. 


\section{OBJETIVOS}

Os objetivos deste estudo foram:

- Determinar a prevalência do gene shf em amostras de EAEC típicas e atípicas recentemente isoladas em um estudo epidemiológico sobre a etiologia da diarréia aguda na infância na cidade de Salvador (BA).

- Avaliar o envolvimento da proteína Shf no estabelecimento da adesão agregativa e na capacidade de formação de biofilme de EAEC típica e atípica. 


\section{MATERIAL E MÉTODOS}

\subsection{Meios de cultura e soluções}

Todos os meios de cultura utilizados para o cultivo e manutenção das amostras bacterianas, assim como as soluções utilizadas nas diversas técnicas descritas a seguir, foram preparados de acordo com Sambrook et al. (1989). Exceto quando indicado, os meios de cultivo bacteriano foram de procedência Difco ${ }^{\circledR}$ (Difco, Reino Unido) e os sais e reagentes de procedência Merck® (Merck, Alemanha) ou Sigma ${ }^{\circledR}$ (Sigma, EUA).

\subsection{Amostras bacterianas}

Foram empregadas neste estudo as amostras de EAEC 042 e 2871-1, classificadas respectivamente como típica e atípica. A amostra 042 (sorotipo O44:H18) foi isolada de um caso de diarréia no Peru (NATARO et al., 1985), apresenta o padrão de adesão agregativa típico e tem sido amplamente empregada na caracterização dos fatores de virulência descritos em EAEC. A amostra 2871-1 (sorotipo O4:H33) foi isolada de um caso de diarréia em São Paulo (GOMES et al., 1998), apresenta o padrão de adesão agregativa típico e foi caracterizada como desprovida de todos os marcadores de virulência de EAEC, apresentando apenas o gene shf (ELIAS et al., 2002). Essas amostras foram classificadas como típica e atípica pela presença e ausência do gene aggR, respectivamente (HARRINGTON et al., 2006).

Como controles positivos nas reações de PCR foram empregadas as seguintes amostras de EAEC: 042 (sorotipo O44:H18), nas reações de amplificação de aaiA, aggR, shf, shf cloning, capU e virK; C1096 (sorotipo O4:HNT), nas reações de amplificação de pilS (COBELJIC et al., 1996); RN785-1 (sorotipo 01:HNT), nas reações de amplificação de agg3A (ZAMBONI et al., 2004); e A30 (sorogrupo O75), nas reações de amplificação de agg3C (LABIGNE-ROUSSEL; FALKOW, 1988). Como controle negativo foi utilizada a amostra de E. coli DH5a (SAMBROOK et al., 1989). 
Os vetores plasmidiais e os plasmídeos recombinantes utilizados neste estudo estão descritos na Tabela 1, juntamente com as suas respectivas amostras hospedeiras.

Para determinar a prevalência do gene shf em amostras de EAEC foram empregadas 113 amostras isoladas em um estudo epidemiológico sobre a etiologia da doença diarréica aguda, conduzido na cidade de Salvador (BA) (BUERIS et al., 2007). Nesse estudo EAEC esteve associada à diarréia aguda tendo sido o patógeno bacteriano mais prevalente (BUERIS et al., 2007). Dentre essas 113 amostras, apenas as positivas para o gene shf foram empregadas nos ensaio de formação de biofilme e de adesão a células HEp-2.

Tabela 1 - Características dos plasmídeos empregados neste estudo

\begin{tabular}{|c|c|c|c|}
\hline Plasmídeo & Características relevantes & Hospedeira & $\begin{array}{l}\text { Referência ou } \\
\text { origem }\end{array}$ \\
\hline pGEM-T Easy & $\begin{array}{l}\text { Plasmídeo vetor de alto número de } \\
\text { cópias; } 3,0 \mathrm{~kb} ; \mathrm{Amp}^{\mathrm{a}}\end{array}$ & E. coli JM109 & Promega (EUA) \\
\hline pJP5603 & $\begin{array}{l}\text { Plasmídeo vetor suicida de baixo } \\
\text { número de cópias contendo o replicon } \\
\text { R6K; } 3,1 \mathrm{~kb} ; \mathrm{Cm}^{\mathrm{b}}\end{array}$ & E. coli DH5 $\alpha \lambda$ pir & $\begin{array}{l}\text { PENFOLD; } \\
\text { PEMBERTON, } 1992\end{array}$ \\
\hline pFV2 & $\begin{array}{l}\text { Fragmento interno do gene shf } \\
(613 \mathrm{pb}) \text { clonado no sítio múltiplo } \\
\text { de clonagem do vetor pGEM-T Easy; } \\
3,6 \mathrm{~kb} ; \text { Amp }^{\text {a }}\end{array}$ & E. coli JM109 & Este estudo \\
\hline pFV3 & $\begin{array}{l}\text { Fragmento shf do plasmídeo } \\
\text { pFV2 subclonado no sítio de EcoRI do } \\
\text { vetor pJP5603; } 3,7 \mathrm{~kb} ; \mathrm{Cm}^{\mathrm{b}}\end{array}$ & E. coli DH5 $\alpha \lambda$ pir & Este estudo \\
\hline
\end{tabular}

\subsection{Sorogrupagem das amostras de EAEC}

As amostras de EAEC isoladas no estudo epidemiológico realizado na cidade de Salvador (BA) que apresentaram o gene shf foram submetidas à tipagem do antígeno $\mathrm{O}$, empregando os antissoros específicos de $\mathrm{O} 1$ a 0181. Dentre as 41 amostras de EAEC shf+, 28 foram sorogrupadas pela Dra. Carla 
R. Taddei (Laboratório de Bacteriologia, Instituto Butantan, São Paulo) com os antissoros adquiridos do Laboratório de Referência de Escherichia coli da Universidade de Santiago de Compostela (Lugo, Espanha), seguindo a técnica descrita por Guinée (1981). As outras 13 EAEC shf+ foram gentilmente sorogrupadas pela Dra. Kinue Irino (Seção de Bacteriologia, Instituto Adolfo Lutz, São Paulo) empregando os antissoros preparados pelo Instituto Adolfo Lutz e a metodologia descrita por Ewing (1986).

\subsection{Pesquisa dos genes de virulência de EAEC}

\subsubsection{Reação em cadeia da polimerase (PCR)}

A técnica de PCR foi empregada na pesquisa da presença dos seguintes marcadores de virulência de EAEC na amostra 2871-1 (EAEC atípica): aaiA, capU, virk, pilS, agg3A e agg3C (BERNIER et al., 2002; CZECZULIN et al., 1999; DUDLEY et al., 2006a; DUDLEY et al., 2006b). Essa técnica também foi utilizada para a confirmação da presença do gene shf (CZECZULIN et al., 1999) nas amostras protótipo de EAEC deste estudo (042 e 2871-1), para a pesquisa da presença do gene shf na coleção de amostras de EAEC isolada na cidade de Salvador e para a pesquisa da presença do gene aggR nas amostras dessa coleção que albergaram o gene shf. Além disso, através de PCR o fragmento interno referente ao gene shf foi amplificado para posterior clonagem nos vetores utilizados nos experimentos de mutagênese.

Os pares de iniciadores e os ciclos de amplificação utilizados, bem como os tamanhos dos fragmentos amplificados nas reações de PCR deste estudo encontram-se descritos na Tabela 2. Os lisados bacterianos usados como DNA molde foram obtidos da seguinte forma: uma colônia isolada de uma placa de ágar Luria-Bertani (LB) foi transferida para um tubo de polipropileno contendo $500 \mu \mathrm{L}$ de água deionizada estéril, submetida à fervura por 10 min e imediatamente resfriada em banho de gelo. Para cada reação foram utilizados $0,2 \mu \mathrm{M}$ de cada um dos iniciadores (foward e reverse), $1 \mu \mathrm{L}$ do DNA molde e os seguintes reagentes de procedência Invitrogen ${ }^{\circledR}$ (Invitrogen, 
EUA): 2,5 U de Taq DNA Polymerase, $1,5 \mathrm{mM}$ de cloreto de magnésio, tampão de PCR 1x e 0,2 mM da mistura de dNTPs.

Tabela 2 - Seqüência dos iniciadores, ciclos de amplificação e tamanho dos fragmentos amplificados nas reações de PCR deste estudo

\begin{tabular}{|c|c|c|c|c|}
\hline Gene & Seqüências dos iniciadores ${ }^{a}$ & Ciclo de amplificação & Amplicon & Referência \\
\hline shf & $\begin{array}{l}\text { (F) ATGAATTCCACTTTCTCCCGAGACATTC } \\
\text { (R) ATGTCGACCCTTTAGCGGGAGCATTCAT }\end{array}$ & $\begin{array}{l}30 \times\left(1 \min 94^{\circ} \mathrm{C}, 1 \min \right. \\
\left.51^{\circ} \mathrm{C}, 1 \min 72^{\circ} \mathrm{C}\right), 8 \min \\
72{ }^{\circ} \mathrm{C}\end{array}$ & $613 \mathrm{pb}$ & $\begin{array}{l}\text { CZECZULIN et al., } \\
1999\end{array}$ \\
\hline shf cloning & $\begin{array}{l}\text { (F) ATGAATTCATGTTAAACGGAGGG } \\
\text { (R) ATGTCGACTTAGTCATCCGGTAA }\end{array}$ & $\begin{array}{l}30 \times\left(1 \min 94^{\circ} \mathrm{C}, 1 \min \right. \\
\left.58^{\circ} \mathrm{C}, 1 \min 72^{\circ} \mathrm{C}\right), 8 \min \\
72^{\circ} \mathrm{C}\end{array}$ & $843 \mathrm{pb}$ & Este estudo ${ }^{\mathrm{b}}$ \\
\hline pils & $\begin{array}{l}\text { (F) ATGAGCGTCATAACCTGTTC } \\
\text { (R) CTGTTGGTTTCCAGTTTGAT }\end{array}$ & $\begin{array}{l}30 x\left(1 \min 94^{\circ} \mathrm{C}, 1 \mathrm{~min}\right. \\
\left.50^{\circ} \mathrm{C}, 1 \min 72{ }^{\circ} \mathrm{C}\right), 8 \min \\
72{ }^{\circ} \mathrm{C}\end{array}$ & $534 \mathrm{pb}$ & DUDLEY et al., 2006a \\
\hline aaiA & $\begin{array}{l}\text { (F) CCCACGAGTACCAGATAACG } \\
\text { (R) GTTTTCAGGATTGCCATTAG }\end{array}$ & $\begin{array}{l}25 \times\left(45 \operatorname{seg} 94^{\circ} \mathrm{C}, 30 \text { seg }\right. \\
\left.50{ }^{\circ} \mathrm{C}, 1 \min 74^{\circ} \mathrm{C}\right), 8 \mathrm{~min} \\
72{ }^{\circ} \mathrm{C}\end{array}$ & $476 \mathrm{pb}$ & DUDLEY et al., 2006b \\
\hline $\operatorname{agg} 3 A$ & $\begin{array}{l}\text { (F) GGTAACAAGGGAAATATTAGC } \\
\text { (R) GCCCGAAAAATGTCCAGTAT }\end{array}$ & $\begin{array}{l}30 \times\left(1 \min 94{ }^{\circ} \mathrm{C}, 1 \mathrm{~min}\right. \\
\left.60{ }^{\circ} \mathrm{C}, 1 \min 72{ }^{\circ} \mathrm{C}\right), 8 \min \\
72{ }^{\circ} \mathrm{C}\end{array}$ & $462 \mathrm{pb}$ & BERNIER et al., 2002 \\
\hline $\operatorname{agg} 3 C$ & $\begin{array}{l}\text { (F) GTTTGGAACCGGGAATTAACATTG } \\
\text { (R) ATACTTTAGATACCCCTCACGCAG }\end{array}$ & $\begin{array}{l}30 \times\left(1 \min 94^{\circ} \mathrm{C}, 1 \min \right. \\
\left.65{ }^{\circ} \mathrm{C}, 1 \min 72{ }^{\circ} \mathrm{C}\right), 8 \min \\
72{ }^{\circ} \mathrm{C}\end{array}$ & $485 \mathrm{pb}$ & BERNIER et al., 2002 \\
\hline $\operatorname{agg} R$ & $\begin{array}{l}\text { (F) CTAATTGTACAATCGATGTA } \\
\text { (R) ATGAAGTAATTCTTGAAT }\end{array}$ & $\begin{array}{l}30 x\left(1 \min 94{ }^{\circ} \mathrm{C}, 1 \min \right. \\
\left.40{ }^{\circ} \mathrm{C}, 1 \min 72{ }^{\circ} \mathrm{C}\right), 8 \min \\
72{ }^{\circ} \mathrm{C}\end{array}$ & $308 \mathrm{pb}$ & $\begin{array}{l}\text { CZECZULIN et al., } \\
1999\end{array}$ \\
\hline virk & $\begin{array}{l}\text { (F) ATGTTTTCTATAAGTAACTTATCATTTATCGG } \\
\text { (R) TTAATTTGAATTCTGATGTTCTGAG }\end{array}$ & $\begin{array}{l}30 \times\left(30 \operatorname{seg} 94{ }^{\circ} \mathrm{C}, 1 \mathrm{~min}\right. \\
\left.55^{\circ} \mathrm{C}, 1 \min 72^{\circ} \mathrm{C}\right), 8 \mathrm{~min} \\
72{ }^{\circ} \mathrm{C}\end{array}$ & $951 \mathrm{pb}$ & $\begin{array}{l}\text { FUJIYAMA et al., } \\
2008\end{array}$ \\
\hline capU & $\begin{array}{l}\text { (F) ATGAATATACTATTTACGGAATC } \\
\text { (R) CTACAGGCACAGAAAATGCCGATG }\end{array}$ & $\begin{array}{l}30 \times\left(30 \operatorname{seg} 94^{\circ} \mathrm{C}, 1 \mathrm{~min}\right. \\
\left.55{ }^{\circ} \mathrm{C}, 1 \min 72{ }^{\circ} \mathrm{C}\right), 8 \min \\
72{ }^{\circ} \mathrm{C}\end{array}$ & $822 \mathrm{pb}$ & $\begin{array}{l}\text { FUJIYAMA et al., } \\
2008\end{array}$ \\
\hline
\end{tabular}

${ }^{a}(\mathrm{~F})$, iniciador forward; (R), iniciador reverse.

b Iniciadores baseados na seqüência do gene shf depositada no GenBank (número de acesso: AF134403).

\subsubsection{Eletroforese em gel de agarose}

Após amplificação, os produtos foram analisados através de eletroforese em gel de agarose. Os géis foram preparados por aquecimento, 
fundindo-se agarose (Invitrogen) em tampão TBE 0,5x (tris(hidroximetil)aminometano [Tris-HCl] $44,5 \mathrm{mM}$; ácido bórico 44,5 mM; ácido etilenodiaminotetracético [EDTA] $1 \mathrm{mM}$ ), em concentrações finais variadas de (0,7 a 1,0\%, dependendo do tamanho do fragmento analisado). As amostras de DNA resultantes das PCR foram acrescidas de tampão de amostra 1x (azul de bromofenol 0,25\%; xileno cianol 0,25\%; glicerol 30\%). Como marcador de peso molecular foi utilizado o $1 \mathrm{~kb}$ DNA Ladder (Invitrogen), e de concentração de DNA o Low Mass DNA Marker (Invitrogen). Após a corrida eletroforética, realizada sob corrente constante de $80 \mathrm{~V}$ em tampão TBE $(0,5 x)$, os géis foram corados em solução de brometo de etídio na concentração de $10 \mu \mathrm{g} / \mathrm{mL}$ durante $10 \mathrm{~min}$, observados em transiluminador de luz ultravioleta e as imagens foram registradas através do sistema de captação de imagem Alphalmager 2200 (Alpha Innotech, EUA).

\subsection{Ensaio de adesão em células HEp-2}

\subsubsection{Cultivo das células e preparo das microplacas}

As células HEp-2 foram cultivadas em garrafas de $50 \mathrm{~mL}$ (Nunc, EUA) contendo $12 \mathrm{~mL}$ de Meio Mínimo Essencial de Eagle, modificado por Dulbeco (DMEM; Cultilab, Brasil) contendo antibióticos (penicilina, $1000 \mathrm{U} / \mathrm{mL}$; estreptomicina, $1 \mathrm{mg} / \mathrm{mL}$ ), acrescido de $10 \%$ de soro fetal bovino (SFB; Cultilab), e mantidas por 2 a 3 dias a $37{ }^{\circ} \mathrm{C}$ sob atmosfera de $5 \%$ de $\mathrm{CO}_{2}$. Após esse período de incubação, as células foram transferidas para placas de 24 orifícios contendo lamínulas de vidro, em uma concentração de $5 \times 10^{4}$ células $/ \mathrm{mL}$, e incubadas por $48 \mathrm{~h}$ sob as mesmas condições, até que atingissem a confluência de $75 \%$.

\subsubsection{Ensaio da adesão}

O teste de interação com células epiteliais HEp-2 foi realizado de acordo com o protocolo descrito por Cravioto et al. (1979), com algumas modificações. As amostras bacterianas selvagens selecionadas para esse estudo foram inoculadas em $3 \mathrm{~mL}$ de caldo de soja tripticase (TSB) e as 
respectivas amostras mutantes em $3 \mathrm{~mL}$ de caldo TSB contendo canamicina (50 $\mu \mathrm{g} / \mathrm{mL})$, estreptomicina $(100 \mu \mathrm{g} / \mathrm{mL})$ e ácido nalidíxico $(50 \mu \mathrm{g} / \mathrm{mL})$, e incubadas sem agitação a $37{ }^{\circ} \mathrm{C}$ por $18 \mathrm{~h}$. Uma alíquota de $20 \mu \mathrm{L}$ da cultura bacteriana da amostra selvagem ou $40 \mu \mathrm{L}$ das amostras mutantes foram adicionadas a cada orifício da placa contendo a cultura de células HEp-2, previamente lavadas por cinco vezes com tampão salina-fosfato (PBS) $1 \mathrm{x}$ (cloreto de sódio $137 \mathrm{mM}$; cloreto de potássio 2,7 mM; fosfato de sódio dibásico 8,1 mM; fosfato de potássio monobásico 1,5 Mm; pH 7,4) e acrescidas de 980 ou $960 \mu \mathrm{L}$ de meio DMEM sem antibiótico, contendo $2 \%$ de SFB e $1 \%$ de D-manose. Após incubação por 3 ou $6 \mathrm{~h}$ a $37{ }^{\circ} \mathrm{C}$, as placas foram novamente lavadas por cinco vezes com PBS 1x, a fim de remover as bactérias que não aderiram às células. Nos ensaios de $3 \mathrm{~h}$, as células foram em seguida fixadas com metanol absoluto. Nos ensaios de 6h, após as três primeiras horas de incubação, as placas foram lavadas por cinco vezes com PBS, acrescidas de $1 \mathrm{~mL}$ de meio DMEM sem antibiótico (2\% de SFB e $1 \%$ de D-manose), e incubadas por mais $3 \mathrm{~h}$ a $37{ }^{\circ} \mathrm{C}$. Em seguida, foram novamente lavadas por cinco vezes com PBS e fixadas com metanol absoluto. Após a fixação, as células foram coradas por 5 min com solução corante eosina-azul de metileno em solução a 0,2\% segundo May-Grünwald (Merck) diluído na razão 1:2 em tampão de Sørensen (fosfato de potássio monobásico 8,6 mM; fosfato de sódio dibásico 28,6 mM), e em seguida esse corante foi desprezado sendo então acrescentada a solução corante azur-eosina-azul de metileno segundo Giemsa (Merck) diluída na razão 1:3 em tampão de Sørensen, por 20 min. Após lavagem para retirada do excesso de corante, as lamínulas foram secas em temperatura ambiente e montadas em lâminas para microscopia com Entellan (Merck). As lâminas foram analisadas através de microscopia óptica comum, em aumento de 1.000 vezes.

\subsection{Avaliação da capacidade de formação de biofilme in vitro}

A quantificação da formação de biofilme foi realizada segundo o protocolo descrito por Sheikh et al. (2001), apresentado a seguir. As amostras bacterianas foram cultivadas em $3 \mathrm{~mL}$ de caldo LB a $37^{\circ} \mathrm{C}$ sem agitação durante 18h. A partir deste cultivo, $2 \mu \mathrm{L}$ foram inoculados em $200 \mu \mathrm{L}$ de meio 
DMEM (Cultilab), suplementado com $0,4 \%$ de glicose, em placas de poliestireno de fundo redondo de 96 poços. Após incubação a $37{ }^{\circ} \mathrm{C}$ durante $24 \mathrm{~h}$ o meio de cultura foi aspirado e os poços foram lavados gentilmente por três vezes com tampão PBS. O biofilme foi corado com solução de cristalvioleta a $0,5 \%$ por $5 \mathrm{~min}$ e a placa foi seca à temperatura ambiente. Em seguida, $200 \mu \mathrm{L}$ de etanol $95 \%$ foram adicionados a cada um dos poços para solubilização do corante e após 2 min à temperatura ambiente, $150 \mu \mathrm{L}$ desse volume foram transferidos para outra placa de poliestireno, para leitura da absorbância de cada poço em comprimento de onda de $595 \mathrm{~nm}$ no leitor de ELISA Multiskan EX (Labsystems, EUA). As amostras de EAEC 042 e E. coli DH5a foram empregadas como controles positivo e negativo de formação de biofilme, respectivamente.

\subsection{Mutação do gene shf nas amostras 042 e 2871-1}

Para a mutagênese no gene shf foi utilizada a estratégia de mutação não polar empregando o vetor suicida pJP5603 (PENFOLD; PEMBERTON, 1992). Em resumo, um fragmento interno do gene shf foi clonado neste vetor e transformado em uma amostra de $E$. coli lisogenizada com o fago lambda ( $E$. coli DH5a入pir). Em seguida essa amostra foi conjugada com as amostras selvagens e, através de recombinação homóloga, ocorreu a inserção do plasmídeo recombinante pJP5603 no gene shf provocando a inativação do mesmo. Para a realização desta metodologia é necessário que as amostras selvagens apresentem resistência a algum antibiótico para seleção após a etapa de conjugação. A amostra 042 apresenta resistência natural aos antibióticos tetraciclina, estreptomicina e cloranfenicol. Já a amostra 2871-1 não apresentou resistência a nenhum dos antibióticos comercialmente disponíveis (dados não apresentados). Por esse motivo, foi necessário selecionar um mutante espontâneo ao ácido nalidíxico da amostra 2871-1.

\subsubsection{Obtenção da amostra 2871-1 resistente ao ácido nalidíxico}

A amostra 2871-1 selvagem foi cultivada em $100 \mathrm{~mL}$ de caldo LB sem adição de antibiótico a $37^{\circ} \mathrm{C}$ sob agitação de $250 \mathrm{rpm}$ durante $18 \mathrm{~h}$. A seguir, 
esse cultivo foi centrifugado por 15 min a 4.000 g na centrífuga Himac CR21E (Hitachi, Japão) e o sedimento ressuspenso em $5 \mathrm{ml}$ de tampão PBS 1x. Um $\mathrm{mL}$ dessa suspensão foi semeado em placas de ágar LB com adição de 50 $\mu \mathrm{g} / \mathrm{mL}$ de ácido nalidíxico e as placas foram incubadas por $18 \mathrm{~h}$ a $37 \stackrel{\circ}{\circ}$. Após essa incubação, colônias de mutantes espontâneos resistentes ao ácido nalidíxico foram selecionadas e analisadas através de testes bioquímicos para confirmação da espécie E. coli (BOPP et al., 1999).

Após a obtenção do mutante, a sua curva de crescimento em caldo TSB foi avaliada em comparação à amostra selvagem, com a finalidade de demonstrar que a mutação que resultou na resistência ao ácido nalidíxico não alterou o seu padrão de crescimento.

As curvas de crescimento da amostra protótipo 2871-1 e da 2871-1 resistente a ácido nalidíxico (2871-1/Nal), foram obtidas correlacionando as leituras de absorbância dos meios de cultura em determinados intervalos de tempo, segundo as condições de cultivo descritas a seguir. Inicialmente a amostra protótipo foi cultivada em $3 \mathrm{~mL}$ de caldo TSB e a mutante em $3 \mathrm{~mL}$ de caldo TSB acrescido de $50 \mu \mathrm{g} / \mathrm{mL}$ de ácido nalidíxico, ambas a $37 \stackrel{\circ}{\circ} \mathrm{C}$ por $18 \mathrm{~h}$. Uma alíquota de $1 \mathrm{~mL}$ dessas culturas foi em seguida transferida a $100 \mathrm{~mL}$ de TSB ou TSB acrescido de ácido nalidíxico (para a amostra mutante) e esses meios foram incubados a $37 \stackrel{\circ}{\circ}$ sob agitação de $300 \mathrm{rpm}$. O crescimento bacteriano de cada uma das amostras foi monitorado a cada 30 min durante $8 \mathrm{~h}$, através de leituras de absorbância em comprimento de onda de $600 \mathrm{~nm}$, utilizando o espectrofotômetro Ultrospec 2000 (Pharmacia Biotech, EUA).

\subsubsection{Clonagem do gene shf no vetor de clonagem pGEM-T Easy}

\subsubsection{Obtenção do inserto shf}

O gene shf foi inicialmente clonado no vetor pGEM-T Easy (Promega) para posterior clonagem no vetor pJP5603. O fragmento interno do gene shf de $613 \mathrm{pb}$, foi amplificado através de PCR (item 3.4.1) a partir do DNA da amostra 042, utilizando os iniciadores $\operatorname{shf}(\mathrm{F})$ e $\operatorname{shf}(\mathrm{R})$ (Tabela 2). Após a eletroforese em gel de agarose (item 3.4.2), o fragmento amplificado foi excisado do gel e foi purificado com auxílio do DNA and Gel Band Purification 
Kit (GE Healthcare, Reino Unido). A quantificação foi realizada comparando-se a intensidade da banda obtida com as bandas do marcador Low DNA Mass Ladder (Invitrogen) em eletroforese em gel de agarose a 1\% (item 3.4.2).

\subsubsection{Ligação do inserto ao vetor pGEM-T Easy}

$O$ inserto do fragmento interno do gene shf de $613 \mathrm{pb}$, obtido a partir da amostra 042 foi clonado no vetor comercial pGEM-T Easy (Promega), segundo recomendações do fabricante. A quantidade de inserto adicionado à mistura foi calculada de forma que representasse aproximadamente três vezes a concentração do vetor. A reação de ligação foi incubada por $18 \mathrm{~h}$ à temperatura ambiente.

\subsubsection{Transformação através de eletroporação}

Para a eletroporação das reações de ligação descritas anteriormente, as células eletrocompetentes foram preparadas conforme descrição a seguir. A amostra de E. coli JM109 foi pré-cultivada em $3 \mathrm{~mL}$ de caldo LB durante $18 \mathrm{~h}$ a $37^{\circ} \mathrm{C}$, sob agitação constante de $300 \mathrm{rpm}$. Uma alíquota de $2 \mathrm{~mL}$ de préinóculo da amostra foi transferida para $250 \mathrm{~mL}$ de caldo LB e a cultura cultivada sob as mesmas condições anteriores, até atingir a absorbância de 0,5 a 0,6 em comprimento de onda de $600 \mathrm{~nm}$, determinada no espectrofotômetro Ultrospec 2000 (Pharmacia Biotech).

As células bacterianas JM109 foram então incubadas em banho de gelo por $15 \mathrm{~min}$, transferidas para um tubo de centrifugação pré-resfriado e centrifugadas na centrífuga Himac CR21E (Hitachi), por $20 \mathrm{~min}$ a $5.000 \mathrm{~g}$ sob refrigeração de $4 \stackrel{\circ}{\circ}$. O sobrenadante foi descartado e o sedimento foi lavado duas vezes com $250 \mathrm{~mL}$ de água deionizada estéril resfriada a $4 \stackrel{\circ}{\circ} \mathrm{C}$. As células foram gentilmente ressuspensas em $30 \mathrm{~mL}$ de glicerol a $10 \%$ resfriado a $4{ }^{\circ} \mathrm{C}$ e novamente centrifugadas a $5.000 \mathrm{~g}$ por $10 \mathrm{~min}$ sob refrigeração a $4 \stackrel{\circ}{\circ} \mathrm{C}$ com auxílio da centrífuga Himac CR21E (Hitachi). Ao sedimento bacteriano foram adicionados $300 \mu \mathrm{L}$ de glicerol a $10 \%$ resfriado a $4 \stackrel{\circ}{\circ}$ para ressuspender gentilmente as células bacterianas. Essa suspensão foi aliquotada em 
volumes de $50 \mu \mathrm{L}$ em tubos de polipropileno de $1,5 \mathrm{ml}$ pré-resfriados e imediatamente congeladas a $-80 \stackrel{\circ}{\circ}$.

Para a transformação, as células competentes foram descongeladas em banho de gelo e $3 \mu \mathrm{L}$ da reação de ligação (item 3.7.2.2) foram adicionados a $50 \mu \mathrm{L}$ de células competentes descongeladas em banho de gelo. Essas misturas foram transferidas para cubetas apropriadas de $0,2 \mathrm{~cm}$ (Biorad, EUA) previamente resfriadas e eletroporadas utilizando o eletroporador GenePulser (Biorad), sob as condições de 2,5 kV, $25 \mu \mathrm{F}$ e controle de pulso a $200 \Omega$.

Após a eletroporação, foi adicionado imediatamente $1 \mathrm{~mL}$ de meio SOC (triptona 2\%; extrato de levedura $0,5 \%$; cloreto de sódio $10 \mathrm{mM}$; cloreto de potássio 2,5 mM; sulfato de magnésio $20 \mathrm{mM}$; cloreto de magnésio $10 \mathrm{mM}$; glicose $20 \mathrm{mM}$ ) à reação, e a mesma foi incubada a $37 \stackrel{\circ}{ } \mathrm{C}$ durante $1 \mathrm{~h}$ sob agitação de $250 \mathrm{rpm}$. A suspensão foi semeada em volumes de 100, $200 \mathrm{e}$ $300 \mu \mathrm{L}$ em placas de ágar LB acrescido de $40 \mu \mathrm{g} / \mathrm{mL}$ de 5-bromo-4-cloro-3indolil- $\beta$-D-galactosídio (X-Gal), $1 \mathrm{mM}$ de isopropil- $\beta$-D-tiogalactosidase (IPTG) e $100 \mu \mathrm{g} / \mathrm{mL}$ de ampicilina, sendo em seguida incubadas a $37^{\circ} \mathrm{C}$ por $18 \mathrm{~h}$.

\subsubsection{Seleção do clone contendo o inserto shf no vetor pGEM-T Easy}

As colônias recombinantes que apresentaram resistência à ampicilina e não metabolizaram o X-Gal (colônias brancas) foram selecionadas para confirmação da clonagem do gene shf, através de uma PCR (item 3.4.1) com os iniciadores $\operatorname{shf}(\mathrm{F})$ e $\operatorname{shf}(\mathrm{R})$. Após análise em eletroforese em gel de agarose (item 3.4.2), uma amostra apresentando o amplicon correspondente ao gene shf foi selecionada para o cultivo em caldo LB contendo ampicilina, sendo em seguida mantida a - $80{ }^{\circ} \mathrm{C}$ com $15 \%$ de glicerol acrescido ao cultivo. Essa amostra foi denominada JM109(pFV2).

O plasmídeo pFV2 foi submetido à extração do DNA plasmidial utilizando-se o Quiagen plasmid mini kit (Quiagen, EUA), a partir de um cultivo a $37 \stackrel{\circ}{\mathrm{C}}$ sob agitação de $300 \mathrm{rpm}$ em $10 \mathrm{~mL}$ de caldo LB contendo ampicilina (100 $\mathrm{\mu g} / \mathrm{mL}$ ), segundo recomendações do fabricante. O plasmídeo pFV2 extraído foi analisado através de eletroforese em gel de agarose a 1\% (item 
3.4.2) e em seguida foi digerido com a enzima de restrição EcoRI (Invitrogen), em volume de $20 \mu \mathrm{L}$ contendo $1 \mu \mathrm{g}$ do DNA plasmidial e $1 \mathrm{U}$ da enzima. As reações foram realizadas empregando-se o tampão apropriado, de acordo com as recomendações do fabricante, durante 3 h de incubação a $37^{\circ} \mathrm{C}$. Em seguida as digestões foram avaliadas através da corrida eletroforética em gel de agarose a $1 \%$ (item 3.4.2). Após confirmação da digestão, os fragmentos contendo as regiões flanqueadas pelas seqüências de restrição para $E c o R I$, foram purificados a partir do gel utilizando o Illustra GFX PCR DNA and Gel Band Purification Kit (GE Healthcare) e quantificados. Os fragmentos foram mantidos a $-20 \stackrel{\circ}{\mathrm{C}}$ para posterior clonagem no vetor suicida pJP5603.

\subsubsection{Subclonagem do inserto shf no vetor pJP5603}

O plasmídeo pJP5603 foi extraído da amostra hospedeira, com auxílio do Quiagen plasmid midi kit (Quiagen), a partir de um volume de $100 \mathrm{~mL}$ de cultura em caldo LB contendo canamicina $(50 \mu \mathrm{g} / \mathrm{mL})$. O plasmídeo extraído foi digerido com a enzima $E c o R I$, seguindo as recomendações do fabricante, e em seguida quantificado em gel de agarose a $0,8 \%$, comparando-se a intensidade da banda obtida com o marcador Low DNA Mass Ladder (Invitrogen).

\subsubsection{Ligação do inserto ao vetor pJP5603}

O inserto flanqueado pela região de restrição para a enzima $E c o R I$ foi liberado do vetor pGEM-T Easy e religado ao vetor pJP5603 utilizando a T4 DNA ligase (Invitrogen), segundo recomendações do fabricante. A concentração de inserto utilizada foi cerca de 5 vezes maior que a concentração do vetor. A reação de ligação foi incubada por $18 \mathrm{~h}$ a $16{ }^{\circ} \mathrm{C}$.

\subsubsection{Transformação por eletroporação}

A amostra de E. coli DH5aApir foi cultivada em $3 \mathrm{~mL}$ de caldo LB acrescido de canamicina $(50 \mu \mathrm{g} / \mathrm{mL})$ por $18 \mathrm{~h}$ a $37^{\circ} \mathrm{C}$, sob agitação constante de $250 \mathrm{rpm}$. Uma alíquota de $2 \mathrm{~mL}$ de pré-inóculo da amostra foi transferida 
para $250 \mathrm{~mL}$ de caldo LB com canamicina $(50 \mu \mathrm{g} / \mathrm{mL})$, e a cultura cultivada sob as mesmas condições anteriores, até atingir a absorbância de 0,5 a 0,6 em comprimento de onda de $600 \mathrm{~nm}$, determinada no espectrofotômetro Ultrospec 2000 (Pharmacia Biotech).

O preparo das células competentes e o protocolo de eletroporação ocorreram conforme descrito no item 3.7.2.3. As bactérias transformadas foram semeadas em placas de ágar LB acrescidas de canamicina $(50 \mu \mathrm{g} / \mathrm{ml})$ em volumes de 100, 200 e $300 \mu \mathrm{L}$ da suspensão bacteriana e foram incubadas por $18 \mathrm{~h}$ a $37^{\circ} \mathrm{C}$.

\subsubsection{Seleção do clone contendo o inserto shf no vetor pJP5603}

As colônias recombinantes que apresentaram resistência à canamicina foram selecionadas para confirmação da clonagem do gene shf, através de uma PCR (item 3.4.1) com os iniciadores $\operatorname{shf}(\mathrm{F})$ e shf( $\mathrm{R}$ ) (Tabela 2). Após análise em eletroforese em gel de agarose a 1\% (item 3.4.2), uma amostra apresentando o amplicon correspondente ao gene shf foi selecionada para o cultivo em caldo LB contendo canamicina, sendo em seguida mantida a - 80 o C com $15 \%$ de glicerol acrescido ao cultivo. Essa amostra foi denominada DH5aגpir(pFV3).

\subsubsection{Conjugação da amostra DH5aגpir(pFV3) com as amostras de EAEC típica e atípica}

As amostras DH5a pir ( $\mathrm{pFV} 3$ ), 042 e 2871-1/Nal foram cultivadas por $18 \mathrm{~h}$ a $37{ }^{\circ} \mathrm{C}$ em $3 \mathrm{~mL}$ de caldo $\mathrm{LB}$ contendo canamicina $(50 \mu \mathrm{g} / \mathrm{ml})$, estreptomicina $(100 \mu \mathrm{g} / \mathrm{ml})$ e ácido nalidíxico $(50 \mu \mathrm{g} / \mathrm{ml})$, respectivamente. A seguir, $300 \mu \mathrm{L}$ do cultivo da amostra doadora DH5a/pir(pFV3) foram adicionados a $100 \mu \mathrm{L}$ de cada uma das amostras receptoras em tubos de polipropileno de $1,5 \mathrm{ml}$ e homogeneizados vagarosamente. Em seguida uma alíquota de $400 \mu \mathrm{L}$ de cada suspensão bacteriana foi aplicada sobre membranas filtrantes de nitrocelulose (poros de 0,22 $\mu \mathrm{m}$ ) estéreis, dispostas sobre placas de ágar LB sem adição de antibiótico, e incubada por 18h a 37 
C. Após a incubação, as membranas foram retiradas das placas, tranferidas para tubos de polipropileno de $50 \mathrm{ml}$ contendo $30 \mathrm{ml}$ de tampão PBS estéril e os tubos foram agitados vigorosamente com auxílio do agitador Fisher Vortex Genie 2 (Fischer Scientific, EUA). A partir dessa suspensão bacteriana foram semeados 50, 100, 200 e $300 \mu \mathrm{L}$ em placas de ágar LB contendo canamicina e estreptomicina (para seleção do transconjugante da amostra 042) ou canamicina e ácido nalidíxico (para seleção do transconjugante da amostra $2871-1 / \mathrm{Nal})$. Em seguida as placas foram incubadas a $37^{\circ} \mathrm{O} \mathrm{C}$ durante $18 \mathrm{~h}$.

Dez transconjugantes de cada conjugação foram selecionados e avaliados inicialmente através de testes bioquímicos para identificação da espécie E. coli e da capacidade de fermentação da lactose, através do cultivo em ágar MacConkey (BOPP et al., 1999). Além disso, a resistência aos antibióticos canamicina e estreptomicina (para o transconjugante da amostra 042) e canamicina e ácido nalidíxico (para seleção do transconjugante da amostra 2871-1/Nal) foram confirmados. Em seguida, a correta inserção do plasmídeo recombinante no gene shf das amostras selvagens foi verificada nos transconjugantes através de PCR (item 3.4.1), com os iniciadores shf cloning ( $F$ e R), descritos na Tabela 2. Essa combinação de iniciadores amplifica no controle positivo (EAEAC 042) um fragmento de $843 \mathrm{pb}$ a partir do codon de iniciação (ATG) até o codon de terminação do gene shf. As amplificações dos fragmentos das PCR foram avaliadas através de gel de agarose 0,8\% (item 3.4.2).

Os transconjugantes selecionados foram denominados 042::pFV3 e 2871-1/Nal::pFV3 e mantidos a $-80^{\circ} \mathrm{C}$ em caldo LB contendo os antibióticos apropriados e $15 \%$ de glicerol. 


\section{RESULTADOS}

\subsection{Prevalência do gene shf em amostras de EAEC isoladas de crianças com diarréia}

Com a finalidade de determinar a prevalência de shf em amostras recentemente isoladas de casos de diarréia no Brasil, foram estudadas 113 amostras de EAEC isoladas em um estudo epidemiológico sobre a etiologia da diarréia aguda realizado na cidade de Salvador, Bahia (BUERIS et al., 2007). Essas amostras foram isoladas apenas de pacientes apresentando diarréia (casos) da faixa etária entre 1 e 10 anos, e foram previamente determinadas como EAEC através da reatividade com a sonda genética CVD432 (aatA), utilizada para o diagnóstico de EAEC (HARRINGTON et al., 2006).

Dentre as 113 amostras de EAEC avaliadas, 41 (36,3\%) foram positivas para o gene shf. Para a análise da prevalência de shf nos subgrupos de EAEC típica e atípica essas 113 amostras foram analisadas quanto à presença ou ausência do gene aggR. Nessa classificação 67 amostras foram determinadas como típicas e 46 como atípicas e o gene shf foi encontrado em 25 amostras do primeiro grupo e 16 amostras do segundo grupo. Em resumo, o gene shf foi detectado em $37.3 \%$ das amostras de EAEC típica e $34,8 \%$ das amostras de EAEC atípicas.

\subsection{Caracterização fenotípica das amostras de EAEC positivas para o gene shf}

Essas 41 amostras positivas para shf foram em seguida avaliadas quanto ao sorogrupo (tipagem do antígeno O), padrão de adesão em células HEp-2 e capacidade de formação de biofilme em poliestireno. Uma vez que não houve diferenças quando esses resultados foram avaliados comparandose os grupos de típica e atípica, os mesmos foram analisados em conjunto e estão apresentados na Tabela 3 e Figura 1.

Dentre as 41 amostras shf positivas, 2 apresentaram o antígeno $\mathrm{O}$ rugoso, 9 não aglutinaram com nenhum dos antissoros disponíveis (antígeno O não-tipável), e as outras 30 apresentaram sorogrupos diversos variando de 
O3 a O181. Em resumo, 21 distintos sorogrupos foram determinados, sem prevalência de nenhum.

Com relação aos padrões de adesão em células HEp-2, 32 (78,1\%) apresentaram o padrão de adesão agregativo, 3 (7,3\%) apresentaram o padrão difuso e 6 (14,6\%) não aderiram às células HEp-2.

A capacidade de formação de biofilme em poliestireno foi observada em todas as amostras de EAEC que albergam o gene shf. A maioria das amostras $(80,5 \%)$ foi capaz de formar biofilmes densos, indicados por altas absorbâncias, ao passo que oito amostras (19.5\%) formaram biofilmes menos densos (Tabela 3). As amostras positivas apresentaram absorbâncias similares às apresentadas pela amostra protótipo 042. Esses resultados podem ser observados individualmente na Figura 1 e em associação com os padrões de adesão e sorogrupo na Tabela 3. Ao analisar o gráfico da formação de biofilme (Figura 1), observa-se que não houve uma diferença significativa da capacidade de formação de biofilme entre as amostras típicas ou atípicas. 
Tabela 3 - Análise das amostras de EAEC shf quanto aos sorogrupos, padrões de adesão, capacidade de formação de biofilme e presença do gene agg $R$

\begin{tabular}{|c|c|c|c|c|}
\hline $\mathbf{N}^{\circ}$ da amostra & Sorogrupo & $\begin{array}{l}\text { Padrão de adesão em } \\
\text { células HEp-2 }\end{array}$ & Presença do gene agg $R$ & $\begin{array}{l}\text { Absorbância do teste de } \\
\text { formação de biofilme }\end{array}$ \\
\hline 114 & O71 & NA & - & 2,237 \\
\hline 128 & O59 & AA & - & 1,784 \\
\hline 198 & $\mathrm{O} 73$ & AA & + & 2,277 \\
\hline 208 & ONT & AA & + & 0,432 \\
\hline 218 & O33 & AA & + & 2,618 \\
\hline 381 & ONT & AA & + & 1,609 \\
\hline 732 & O17 & AA & + & 2,027 \\
\hline 856 & O86 & AA & + & 1,807 \\
\hline 871 & O33 & AA & + & 2,826 \\
\hline 934 & O78 & AA & + & 1,509 \\
\hline 963 & ONT & AA & - & 1,788 \\
\hline 975 & $\mathrm{O} 78$ & AA & + & 1,966 \\
\hline 1005 & OR & AA & - & 3,106 \\
\hline 1024 & O44 & AA & + & 0,915 \\
\hline 1116 & O59 & NA & + & 1,509 \\
\hline 1178 & 0175 & AA & - & 2,492 \\
\hline 1226 & O33 & AA & - & 2,325 \\
\hline 1521 & O3 & DA & - & 0,842 \\
\hline 1539 & O84 & AA & + & 2,329 \\
\hline 1599 & O5 & AA & + & 2,974 \\
\hline 1643 & ONT & DA & - & 2,689 \\
\hline 1678 & 0106 & AA & + & 3,252 \\
\hline 1751 & O15 & DA & + & 1,715 \\
\hline 1757 & O3 & AA & + & 1,326 \\
\hline 2007 & O104 & AA & + & 2,112 \\
\hline 2024 & ONT & NA & - & 1,165 \\
\hline 2225 & 0131 & AA & + & 3,141 \\
\hline 2754 & OR & AA & + & 0,561 \\
\hline 2872 & O181 & AA & - & 1,915 \\
\hline 3043 & O73 & NA & - & 2,372 \\
\hline 3125 & O165 & AA & - & 0,764 \\
\hline 3163 & 0126 & NA & + & 2,504 \\
\hline 3233 & 0175 & AA & - & 2,883 \\
\hline 3601 & O154 & AA & + & 3,302 \\
\hline 3616 & ONT & AA & - & 2,420 \\
\hline 3755 & O33 & AA & + & 2,279 \\
\hline 3807 & O175 & AA & + & 2,247 \\
\hline 3826 & O104 & AA & + & 2,567 \\
\hline 3954 & ONT & AA & + & 2,914 \\
\hline 4028 & ONT & NA & - & 0,874 \\
\hline 4067 & ONT & AA & + & 0,924 \\
\hline
\end{tabular}

ONT, antígeno $O$ não tipável; OR, antígeno O rugoso; NA, não aderente; $A A$, adesão agregativa; DA, adesão difusa. 


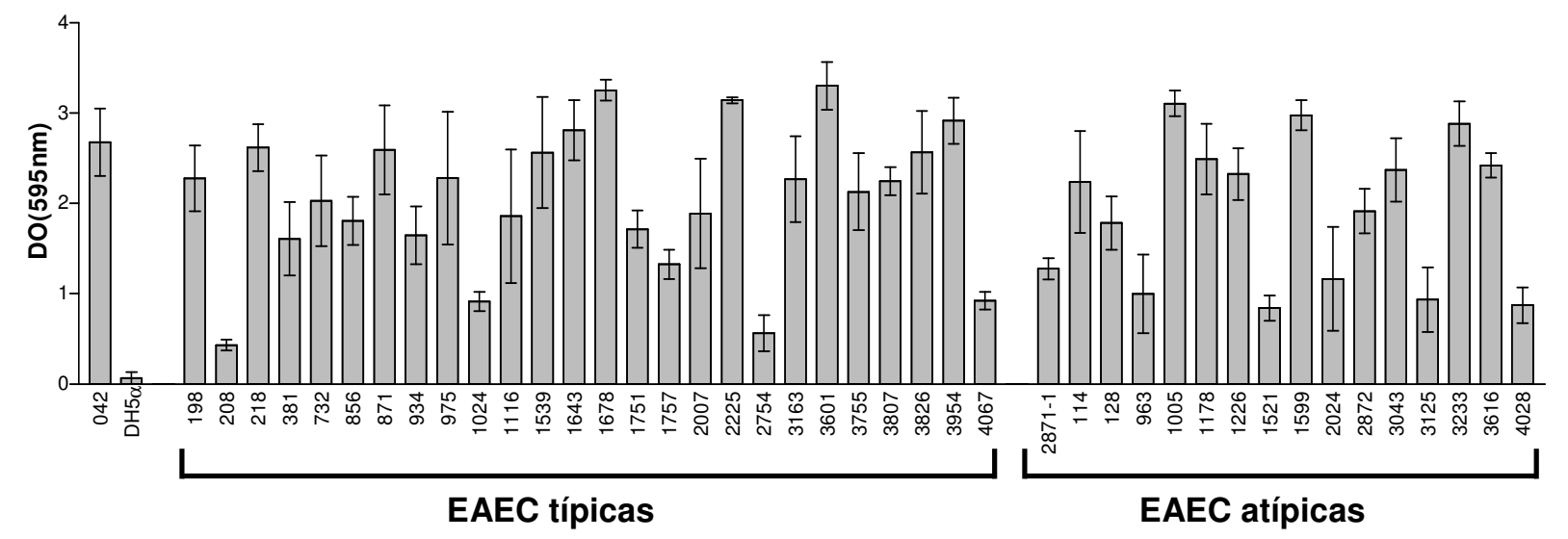

Figura 1 - Capacidade de formação de biofilme em poliestireno apresentada pelas amostras de EAEC típicas e atípicas que albergam o gene shf. Gráfico das absorbâncias em comprimento de onda de $595 \mathrm{~nm}$ das suspensões de cristal violeta em etanol $95 \%$, correspondentes às colorações dos biofilmes formados nas placas de poliestireno após incubação das bactérias em meio DMEM com $0,4 \%$ de glicose a $37 \stackrel{\circ}{ } \mathrm{C}$ em condições estáticas por $24 \mathrm{~h}$. A amostra de EAEC típica 042 foi usada como controle positivo e a amostra $E$. coli $\mathrm{DH} 5 a$ como controle negativo. $\mathrm{O}$ gráfico mostra os resultados das amostras típicas e atípicas separadamente, onde no primeiro grupo estão as amostras típicas e no segundo grupo, a partir da amostra 2871-1 (EAEC atípica), as amostras atípicas.

\subsection{Caracterização fenotípica das amostras de EAEC típica e atípica selecionadas como protótipos}

Inicialmente os padrões de adesão das amostras de EAEC típica (042) e atípica (2871-1) foram confirmados em ensaios com células HEp-2. Os testes foram realizados com os intervalos de incubação bactéria-células epiteliais de $3 \mathrm{~h}$ e $6 \mathrm{~h}$. A Figura 2 apresenta os resultados desses ensaios. Conforme se observa, o padrão de adesão agregativa típica, demonstrando a presença de bactérias aderidas umas as outras em uma configuração semelhante a tijolos empilhados sobre as células e à superfície da lamínula, foi expresso por ambas as amostras de EAEC. Uma vez que esse padrão de adesão em células epiteliais cultivadas define a categoria EAEC (NATARO; KAPER, 1998), a confirmação da expressão desse fenótipo permitiu a continuação desse estudo utilizando essas amostras como protótipos de EAEC típica e atípica. 

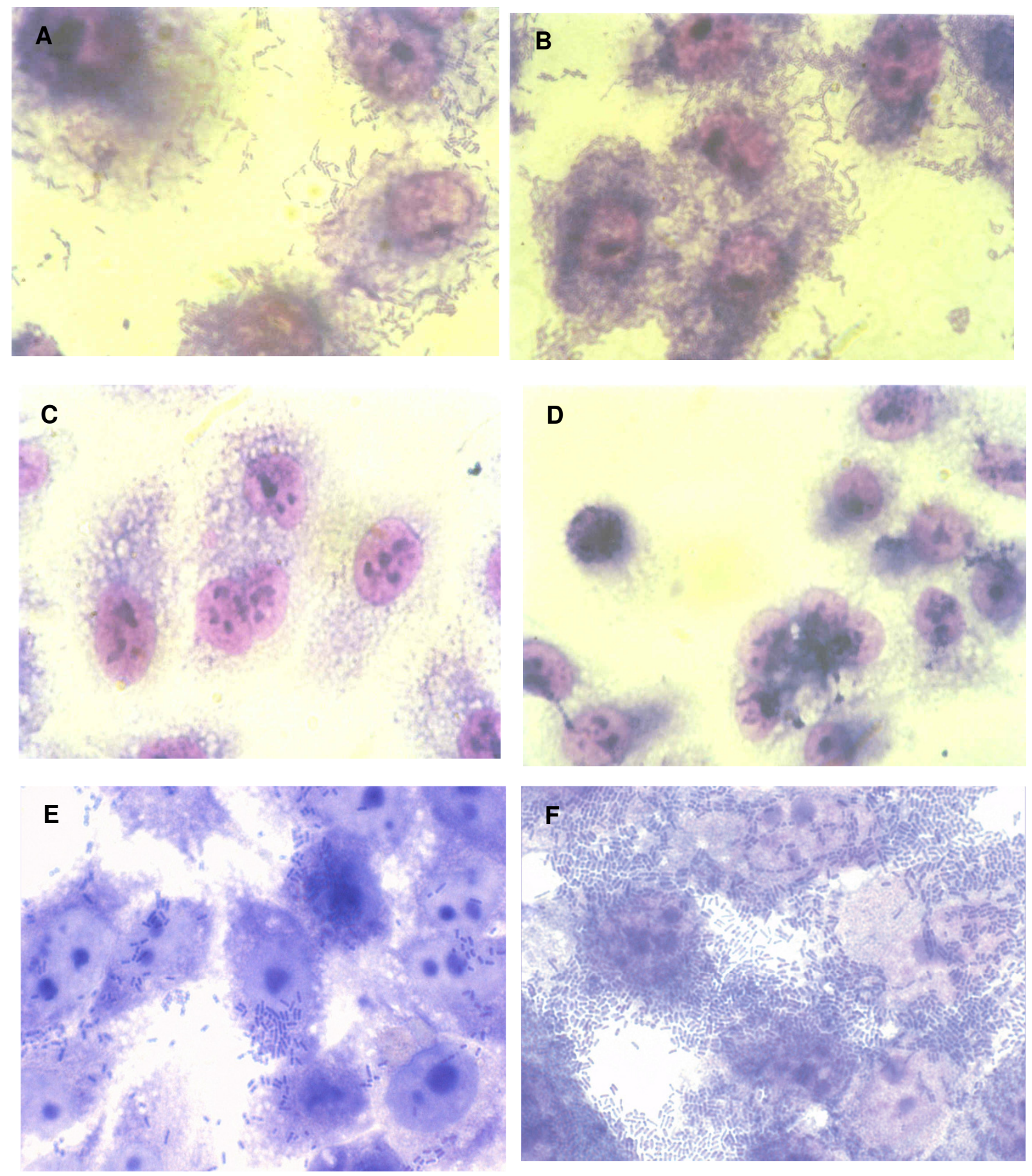

Figura 2 - Padrões de interação das amostras de EAEC 042 (típica) e 2871-1 (atípica) com células HEp-2. As células foram coradas com solução de May-Grünwald/Giemsa. A, padrão agregativo de adesão da amostra 042 em ensaio de $3 \mathrm{~h}$; B, padrão agregativo de adesão da amostra $042 \mathrm{em}$ ensaio de $6 \mathrm{~h}$; $\mathrm{C}$, controle negativo de adesão empregando a $E$. coli $\mathrm{DH} 5 \alpha$ em ensaio de $3 \mathrm{~h} ; \mathrm{D}$, controle negativo de adesão empregando a $E$. coli $\mathrm{DH} 5 \alpha$ em ensaio de $6 \mathrm{~h}$; $\mathrm{E}$, padrão agregativo de adesão da amostra 2871-1 em ensaio de 3h; F, padrão agregativo de adesão da amostra $2871-1$ em ensaio de 6 h. Aumento de 1.000 vezes. 


\subsection{Caracterização genotípica das amostras de EAEC típica e atípica selecionadas como protótipos}

A pesquisa de alguns marcadores de virulência de EAEC foi realizada na amostra de EAEC 2871-1 com o intuito de caracterizar essa amostra quanto à presença de marcadores de EAEC descritos após a publicação relatando o perfil genético desta amostra (ELIAS et al., 2002).

Inicialmente foi confirmada a presença do gene shf em ambas as amostras protótipos 042 e 2871-1. Conforme se observa na Figura 3, houve amplificação do fragmento previsto de 613 pb, confirmando a presença de shf em ambas.

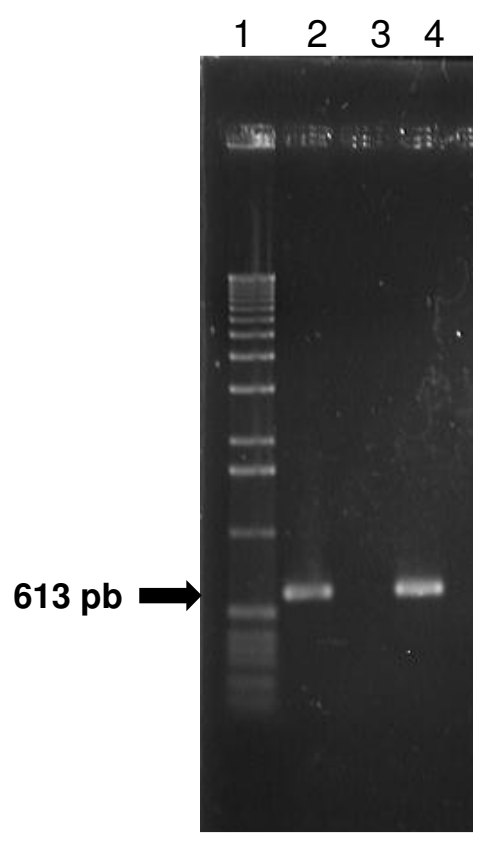

Figura 3 - Pesquisa da presença do gene shf nas amostras de EAEC típica (042) e atípica (2871-1). Eletroforese em gel de agarose $(0,8 \%)$ dos produtos amplificados nas PCR para detecção do gene shf, utilizando o par de iniciadores shf (F e R). O gel foi corado com brometo de etídio e visualizado em transiluminador de luz ultravioleta. Linha 1: marcador $1 \mathrm{~kb}$ ladder (Invitrogen); Linha 2: amostra EAEC típica 042 (controle positivo); Linha 3: amostra E. coli DH5 $\alpha$ (controle negativo); Linha 4: amostra EAEC atípica 2871-1. A seta indica o fragmento de $613 \mathrm{pb}$ correspondente ao fragmento amplificado na reação. 
Após a confirmação da presença do gene shf nas duas amostras selecionadas, os seguintes marcadores de virulência de EAEC foram pesquisados na amostra 2871-1: aaiA, pilS, agg3A, agg3C, virK e capU.

A Figura 4 mostra a reação de amplificação do gene agg3A, o qual codifica a pilina da fímbria AAF/III de EAEC (BERNIER et al., 2002). Pode-se observar a amplificação do fragmento de 462 pb referente e esse gene na amostra RNT785-1, usada como controle positivo. Nas amostras 042 e 28711 , agg3A não foi detectado.

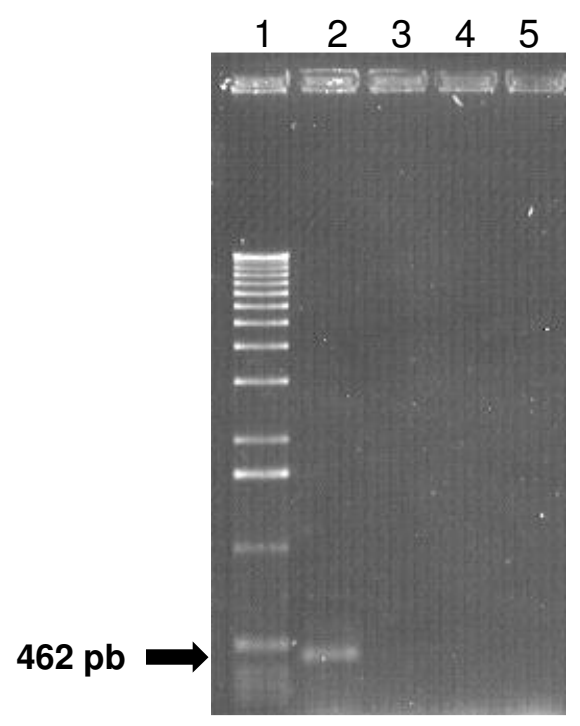

Figura 4 - Pesquisa da presença do gene agg3A nas amostras de EAEC típica (042) e atípica (2871-1). Eletroforese em gel de agarose $(0,8 \%)$ dos produtos amplificados nas PCR para detecção do gene agg3A, utilizando o par de iniciadores agg3A (F e R). O gel foi corado com brometo de etídio e visualizado em transiluminador de luz ultravioleta. Linha 1: marcador 1 kb ladder (Invitrogen); Linha 2: amostra RNT785-1 (controle positivo); Linha 3: amostra EAEC típica 042; Linha 4: amostra EAEC atípica 2871-1; Linha 5: amostra E. coli DH5 $\alpha$ (controle negativo). A seta indica o fragmento de 462 pb correspondente ao fragmento amplificado na reação.

Em seguida, a presença do gene que codifica o usher da fímbria $\mathrm{AAF} / \mathrm{III}(\mathrm{agg} 3 \mathrm{C})$ foi avaliada nessas mesmas amostras. Conforme apresentado na Figura 5, houve amplificação do fragmento previsto de $485 \mathrm{pb}$, correspondente ao gene agg $3 \mathrm{C}$ somente nas amostras A30 (controle positivo) e na 042, enquanto na amostra 2871-1 não houve a detecção desse gene. 


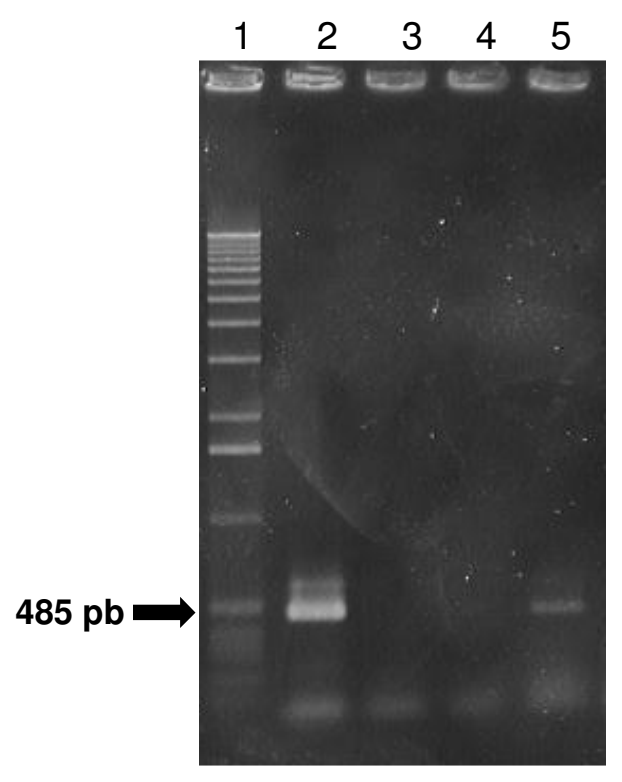

Figura 5 - Pesquisa da presença do gene agg3C nas amostras de EAEC típica (042) e atípica (2871-1). Eletroforese em gel de agarose $(0,8 \%)$ dos produtos amplificados nas PCR para detecção do gene agg3C, utilizando o par de iniciadores agg3C (F e R). O gel foi corado com brometo de etídio e visualizado em transiluminador de luz ultravioleta. Linha 1: marcador $1 \mathrm{~kb}$ ladder (Invitrogen); Linha 2: amostra A30 (controle positivo); Linha 3: amostra E. coli DH5 $\alpha$ (controle negativo); Linha 4: amostra EAEC atípica 2871-1; Linha 5: amostra EAEC típica 042. A seta indica o fragmento de $485 \mathrm{pb}$ correspondente ao fragmento amplificado na reação.

A presença de um dos genes do operon aai (AggR-activated island), localizado em uma ilha de patogenicidade de $117 \mathrm{~kb}$, denominada pheU PAI (DUDLEY et al., 2006b) foi investigada nas amostra 2871-1. A Figura 6 mostra a detecção do gene aaiA de 476 pb na amostra 042, usada como controle positivo e a sua ausência na amostra 2871-1. 


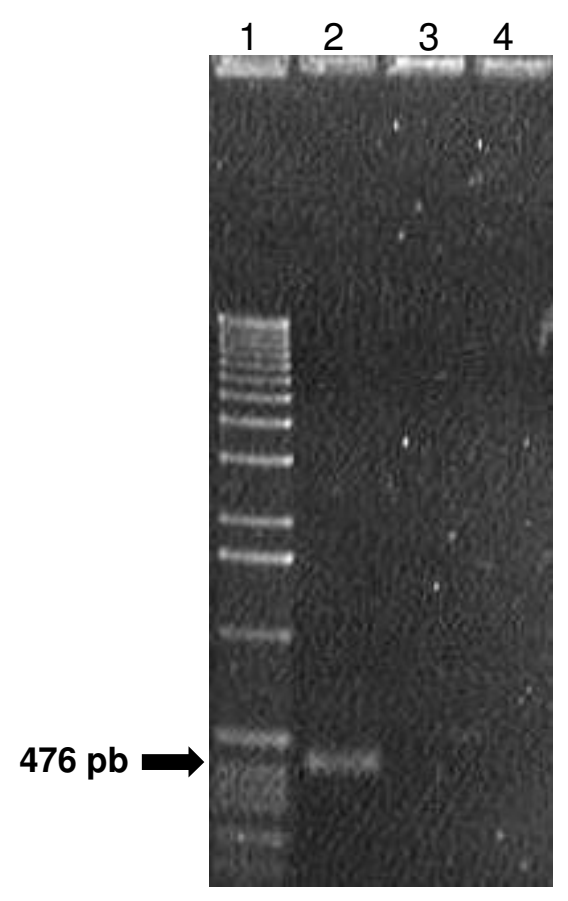

Figura 6 - Pesquisa da presença do gene aaiA nas amostras de EAEC típica (042) e atípica (2871-1). Eletroforese em gel de agarose $(0,8 \%)$ dos produtos amplificados nas PCR para detecção do gene aaiA, utilizando o par de iniciadores aaiA (F e R). O gel foi corado com brometo de etídio e visualizado em transiluminador de luz ultravioleta. Linha 1: marcador $1 \mathrm{~kb}$ ladder (Invitrogen); Linha 2: amostra EAEC típica 042 (controle positivo); Linha 3: amostra EAEC atípica 2871-1; Linha 4: amostra E. coli DH5 $\alpha$ (controle negativo). A seta indica o fragmento de $476 \mathrm{pb}$ correspondente ao fragmento amplificado na reação.

A presença do gene pilS, que codifica a pilina correspondente à subunidade principal do pili tipo IV descrita em uma amostra de EAEC atípica (DUDLEY et al., 2006a), também foi pesquisada nas amostras protótipo deste estudo. A Figura 7 mostra as reações de amplificação do gene pilS. Observase que houve amplificação do fragmento previsto de $534 \mathrm{pb}$, somente na amostra C1096 (controle positivo), enquanto nas amostras 042 e 2871-1 não houve a detecção desse gene. 


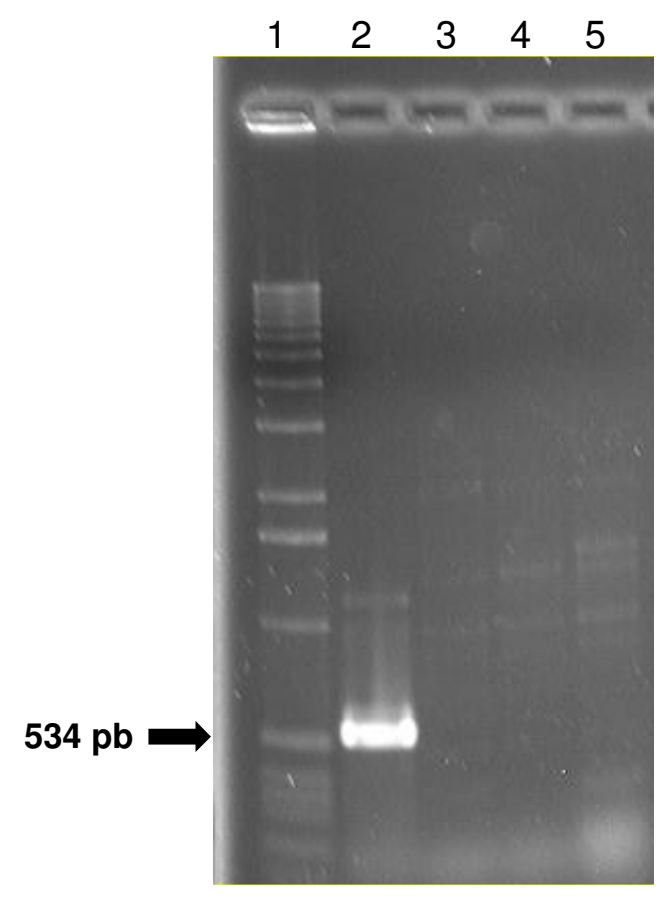

Figura 7 - Pesquisa da presença do gene pilS nas amostras de EAEC típica (042) e atípica (2871-1). Eletroforese em gel de agarose $(0,8 \%)$ dos produtos amplificados nas PCR para detecção do gene pilS, utilizando o par de iniciadores pilS (F e R). O gel foi corado com brometo de etídio e visualizado em transiluminador de luz ultravioleta. Linha 1: marcador $1 \mathrm{~kb}$ ladder (Invitrogen); Linha 2: amostra C1096 (controle positivo); Linha 3: amostra EAEC típica 042; Linha 4: amostra EAEC atípica 2871-1; Linha 5: amostra E. coli $\mathrm{DH} 5 \alpha$ (controle negativo). A seta indica o fragmento de 534 pb correspondente ao fragmento amplificado na reação.

O gene plasmidial shf foi descrito no plasmídeo pAA2 da amostra 042 onde faz parte de um grupo de genes denominado cap cluster, juntamente com os genes virk e capU (FUJIYAMA et al., 2008). Esses dois genes também foram pesquisados nas amostras deste estudo com o intuito de verificar se 0 gene shf detectado na amostra 2871-1 estava ou não presente com o cap cluster.

A Figura 8 mostra a amplificação de um fragmento de $951 \mathrm{pb}$ correspondente ao gene virK em ambas as amostras protótipos deste estudo. 


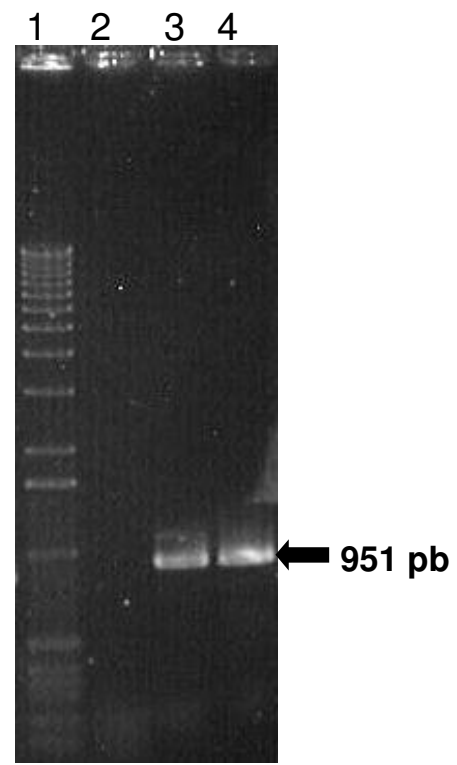

Figura 8 - Pesquisa da presença do gene virK nas amostras de EAEC típica (042) e atípica (2871-1). Eletroforese em gel de agarose $(0,7 \%)$ dos produtos amplificados nas PCR para detecção do gene virK, utilizando o par de iniciadores virK (F e R). O gel foi corado com brometo de etídio e visualizado em transiluminador de luz ultravioleta. Linha 1: marcador $1 \mathrm{~kb}$ ladder (Invitrogen); Linha 2: amostra E. coli DH5 $\alpha$ (controle negativo); Linha 3: amostra EAEC típica 042 (controle positivo); Linha 4: amostra EAEC atípica 2871-1; A seta indica o fragmento de $951 \mathrm{pb}$ correspondente ao fragmento amplificado na reação.

Na Figura 9 estão apresentadas as reações de amplificação do gene capU, onde se observa a amplificação de um fragmento de 822 pb correspondente a esse gene capU nas amostras 042 e 2871-1. 


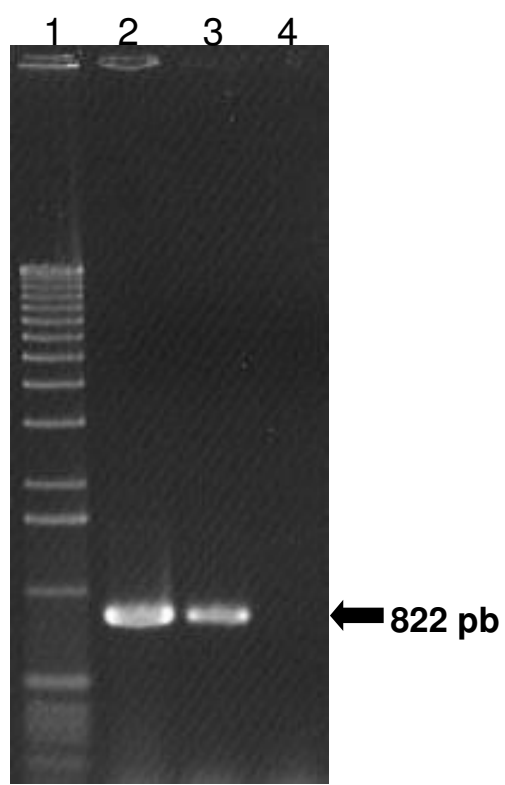

Figura 9 - Pesquisa da presença do gene capU nas amostras de EAEC típica (042) e atípica (2871-1). Eletroforese em gel de agarose $(0,7 \%)$ dos produtos amplificados nas PCR para detecção do gene capU, utilizando o par de iniciadores capU (F e R). O gel foi corado com brometo de etídio e visualizado em transiluminador de luz ultravioleta. Linha 1: marcador $1 \mathrm{~kb}$ ladder (Invitrogen); Linha 2: amostra EAEC típica 042 (controle positivo); Linha 3: amostra EAEC atípica 2871-1; Linha 4: amostra E. coli $\mathrm{DH} 5 \alpha$ (controle negativo); A seta indica o fragmento de $822 \mathrm{pb}$ correspondente ao fragmento amplificado na reação.

Em resumo, a presença do gene shf foi confirmada nas amostras de EAEC típica (042) e atípica (2871-1) selecionadas como protótipos para este estudo. Com relação à amostra 2871-1, foi verificada a presença do cap cluster, ou seja, o gene shf está acompanhado dos genes virk e capU de forma semelhante à amostra 042. Além desses três genes, a amostra 2871-1 é desprovida de todos os marcadores de virulência associados com EAEC, inclusive o gene que codifica o regulador global dos genes de virulência de EAEC (aggR). 


\subsection{Determinação do papel da proteína Shf na adesão agregativa e na capacidade de formação de biofilme de EAEC típica e atípica}

\subsubsection{Mutagênese de shf nas amostras 042 e 2871-1}

Para realização dos experimentos de mutagênese em shf na amostra 2871-1 foi necessário selecionar um mutante espontâneo ao ácido nalidíxico, uma vez que ela não apresentou resistência aos antimicrobianos disponíveis comercialmente (dados não apresentados). Após a seleção do mutante 2871$1 / \mathrm{Nal}$ o mesmo foi analisado quanto à capacidade de crescimento em caldo TSB a fim de verificar se em decorrência da mutação não havia ocorrido alguma alteração na sua curva de crescimento.

A curva de crescimento da amostra mutante 2871-1/Nal em comparação com a amostra selvagem está apresentada na Figura 10, onde se observa que as duas curvas de crescimento foram similares.

Em seguida, a amostra $2871-1 / \mathrm{Nal}$ também foi avaliada no teste de adesão em células HEp-2, onde apresentou o mesmo padrão agregativo em comparação à amostra selvagem (Figura 15). Esses dados indicam que o mutante resistente ao ácido nalidíxico manteve as características de multiplicação e de adesão in vitro, permitindo o prosseguimento dos experimentos de mutação em shf. 


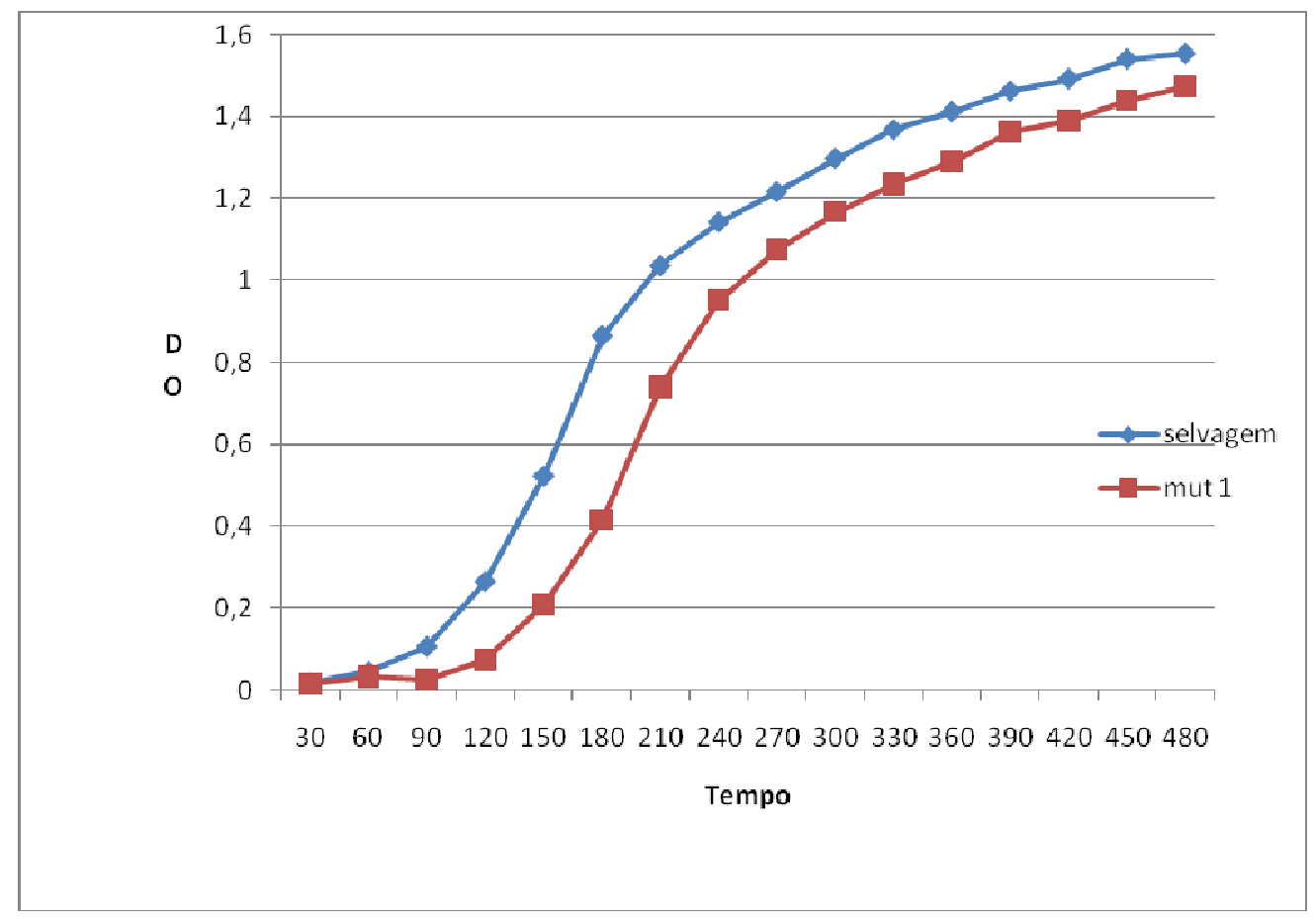

Figura 10 - Curva de crescimento da amostra 2871-1 selvagem e mutante resistente ao ácido nalidíxico (2871-1/Nal). As amostras foram cultivadas em caldo TSB sob agitação constante de $300 \mathrm{rpm}$ a $37^{\circ} \mathrm{C}$. As absorbâncias dos cultivos das amostras 2871-

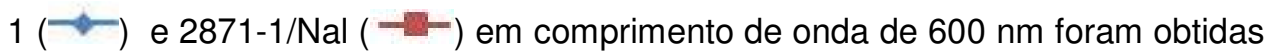
em intervalos de 30 min durante $8 \mathrm{~h}$.

A etapa inicial da mutagênese em shf incluiu a clonagem de uma seqüência interna desse gene no vetor pGEM-T Easy, seguida da retirada desse inserto com uma enzima de restrição e posterior subclonagem no vetor pJP5603, para inativação do gene shf nas amostras selvagens através de recombinação homologa.

O fragmento interno do gene shf de 613 pb foi amplificado a partir da amostra 042, purificado e quantificado através de eletroforese em gel de agarose. Observa-se na Figura 11 o fragmento shf purificado na concentração de $\sim 100 \mathrm{ng} / \mu \mathrm{l}$. 


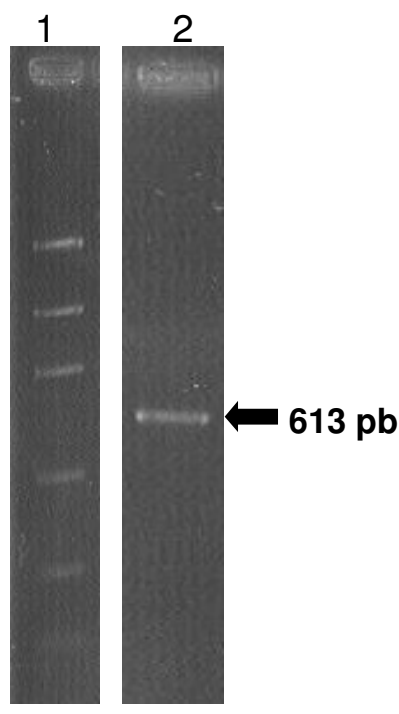

Figura 11 - Purificação do fragmento shf amplificado por PCR. Eletroforese em gel de agarose $(1,5 \%)$ do produto amplificado na reação de PCR para o gene shf, utilizando os iniciadores $\operatorname{shf}(\mathrm{F}$ e R) e o DNA da amostra 042. O gel foi corado com brometo de etídio e visualizado em transiluminador de luz ultravioleta. Linha 1: Ladder Low Mass (Invitrogen); Linha 2: fragmento shf amplificado por PCR após purificação. A seta indica o fragmento de $613 \mathrm{pb}$.

Em seguida, esse fragmento foi ligado ao vetor pGEM-T Easy e essa ligação foi eletroporada em E. coli JM109. Os transformantes resultantes foram selecionados em placa de ágar LB contendo IPTG, X-Gal e ampicilina. Dez colônias brancas que cresceram nesse meio foram escolhidas para a confirmação da clonagem do inserto através de uma PCR para detecção do gene shf. Uma das colônias que apresentou amplificação do fragmento esperado $(613 \mathrm{pb})$ foi selecionada para cultivo e extração do DNA plasmidial para análise através de digestão com a enzima de restrição EcoRI. O sítio de restrição para essa enzima está localizado no sítio múltiplo de clonagem do vetor PGEM-T Easy e a seqüência do gene shf da amostra 042 não apresenta sítios de restrição para essa enzima. Dessa forma, a digestão do plasmídeo recombinante com EcoRl liberou o inserto shf do vetor (Figura 12), confirmando a sua correta clonagem. Esse plasmídeo foi denominado pFV2. 


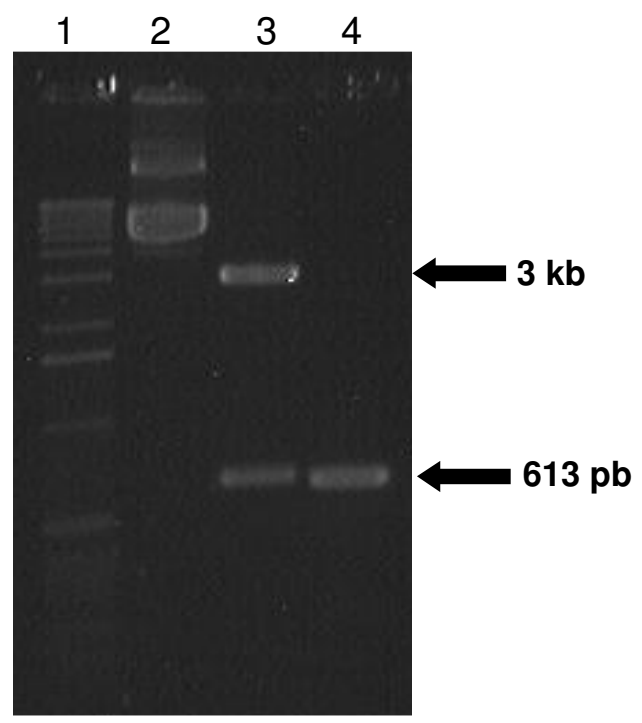

Figura 12 - Análise do perfil de restrição do plasmídeo pFV2. Eletroforese em gel de agarose $(0,8 \%)$ do DNA plasmidial extraído da amostra JM109(pFV2) antes e após a digestão com a enzima EcoRl. O gel foi corado com brometo de etídio e visualizado em transiluminador de luz ultravioleta. Linha 1: marcador $1 \mathrm{~kb}$ ladder (Invitrogen); Linha 2: plasmídeo pFV2 não digerido; Linha 3: plasmídeo pFV2 digerido com a enzima EcoRl; Linha 4: inserto shf purificado utilizado na clonagem. As setas indicam o inserto shf (613 pb) e o vetor pGEM-T Easy linearizado (3 kb).

Após a obtenção do clone pFV2 contendo uma seqüência interna do shf clonado, o fragmento foi liberado através da digestão do pFV2 com EcoRI. Essa purificação foi analisada e quantificada através de eletroforese em gel de agarose. Observa-se na Figura 13 o fragmento shf purificado na concentração de $\sim 20 \mathrm{ng} / \mu \mathrm{l}$. 


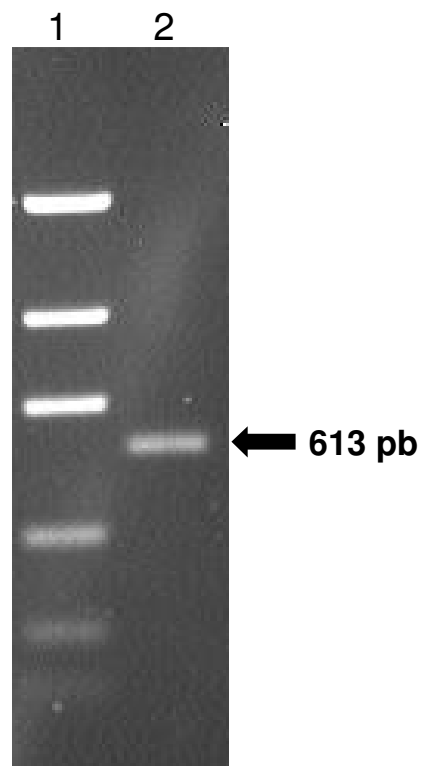

Figura 13 - Purificação do fragmento shf clonado no plasmídeo pFV2. Eletroforese em gel de agarose $(0,8 \%)$ do produto de 613 pb da digestão do plasmídeo pFV2 com a enzima EcoRl. O gel foi corado com brometo de etídio e visualizado em transiluminador de luz ultravioleta. Linha 1: Ladder Low Mass (Invitrogen); Linha 2: inserto do plasmídeo pFV2 após digestão com EcoRl e purificação. A seta indica o fragmento de $613 \mathrm{pb}$.

Para a subclonagem desse fragmento shf (contendo os sítios para EcoRI em suas extremidades) no vetor pJP5603, procedeu-se à extração e purificação desse plasmídeo, seguida de sua digestão com a enzima EcoRI e posterior ligação ao inserto shf. Essa ligação foi eletroporada em E. coli DH5aגpir e os transformantes foram selecionados em placa de ágar LB contendo canamicina. Dez colônias que cresceram nesse meio foram escolhidas para a confirmação da clonagem do inserto através de uma PCR para detecção do gene shf. Uma das colônias que apresentou amplificação do fragmento esperado de $613 \mathrm{pb}$ (Figura 14) foi selecionada para cultivo e extração do DNA plasmidial para análise através de digestão com a enzima de restrição $E c o R I$. A digestão do plasmídeo recombinante com EcoRI liberou o inserto shf do vetor, confirmando a sua correta clonagem. Esse plasmídeo foi denominado $\mathrm{pFV} 3$. 


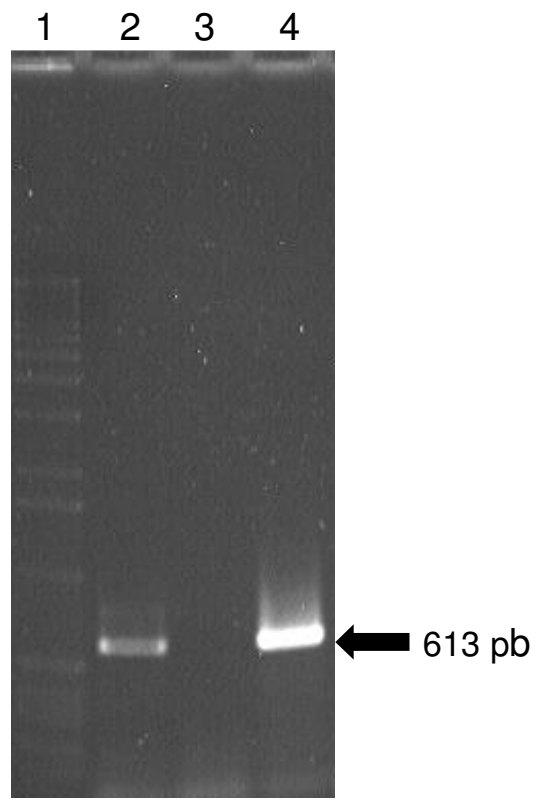

Figura 14 - Confirmação da presença do fragmento shf no plasmídeo pFV3 através de PCR. Eletroforese em gel de agarose $(0,8 \%)$ do produto amplificado na reação de PCR para o gene shf, utilizando os iniciadores shf ( $F$ e $R$ ) e o DNA da amostra DH5a pir(pFV3). O gel foi corado com brometo de etídio e visualizado em transiluminador de luz ultravioleta. Linha 1: Ladder Low Mass (Invitrogen); Linha 2: amostra EAEC típica 042 (controle positivo); Linha 3: amostra E. coli DH5a (controle negativo); Linha 4: amostra DH5axpir (pFV3). A seta indica o fragmento de $613 \mathrm{pb}$.

Após a clonagem do fragmento interno do gene shf no vetor suicida pJP5603, foi realizada a recombinação homóloga entre o plasmídeo pFV3 e o gene shf das amostras selvagens de EAEC 042 e 2871-1/Nal. Esse evento foi realizado através de conjugações entre a amostra doadora DH5axpir (pFV3) e as receptoras 042 e $2871-1 / \mathrm{Nal}$.

Foram selecionados dez transconjugantes de cada conjugação denominados TC042 de 1 a 10 (resultantes da conjugação com a 042) e TC2871 de 1 a 10 (resultantes da conjugação com a 2871-1/Nal). As vinte colônias foram então semeadas em ágar MacConkey, em caldo LB com os respectivos antibióticos de seleção, e avaliadas por testes bioquímicos para identificação de espécie. Após as confirmações da capacidade de fermentação da lactose, da determinação bioquímica da espécie $E$. coli e das resistências aos respectivos antibióticos, esses transconjugantes foram avaliados quanto à 
correta inativação do gene shf. Para isso foi realizada uma PCR utilizando os iniciadores $s h f_{\text {cloning }}(\mathrm{F}$ e R), o qual amplifica um fragmento de $843 \mathrm{pb}$ com base na seqüência de nucleotídeos do gene shf da amostra 042 depositada no GenBank. Não houve amplificação de nenhum fragmento nos dez transconjugantes de ambas as amostras. Dessa forma os transconjugantes TC042-1 e TC287-1 foram selecionados para posteriores análises e essas amostras foram denominados 042::pFV3 e 2871/Nal::pFV3, respectivamente.

\subsubsection{Análise fenotípica dos mutantes shf ${ }^{-}$}

Para analisar o efeito da mutação em shf nos fenótipos de adesão agregativa e de formação de biofilme, os mutantes 042::pFV3 e 2871/Nal::pFV3 foram analisados nos ensaios de adesão em células HEp-2 e de formação de biofilme em placas de poliestireno.

A Figura 15 mostra o resultado dos ensaios de adesão das amostras 042 e $2871-1 / \mathrm{Nal}$ em comparação com os seus respectivos mutantes shf . Observa-se a completa perda da capacidade de adesão nas duas amostras mutantes (042::pFV3 e 2871/Nal::pFV3). Esses resultados demonstram que a mutação em shf destituiu a capacidade de adesão tanto em EAEC típica como em atípica. 

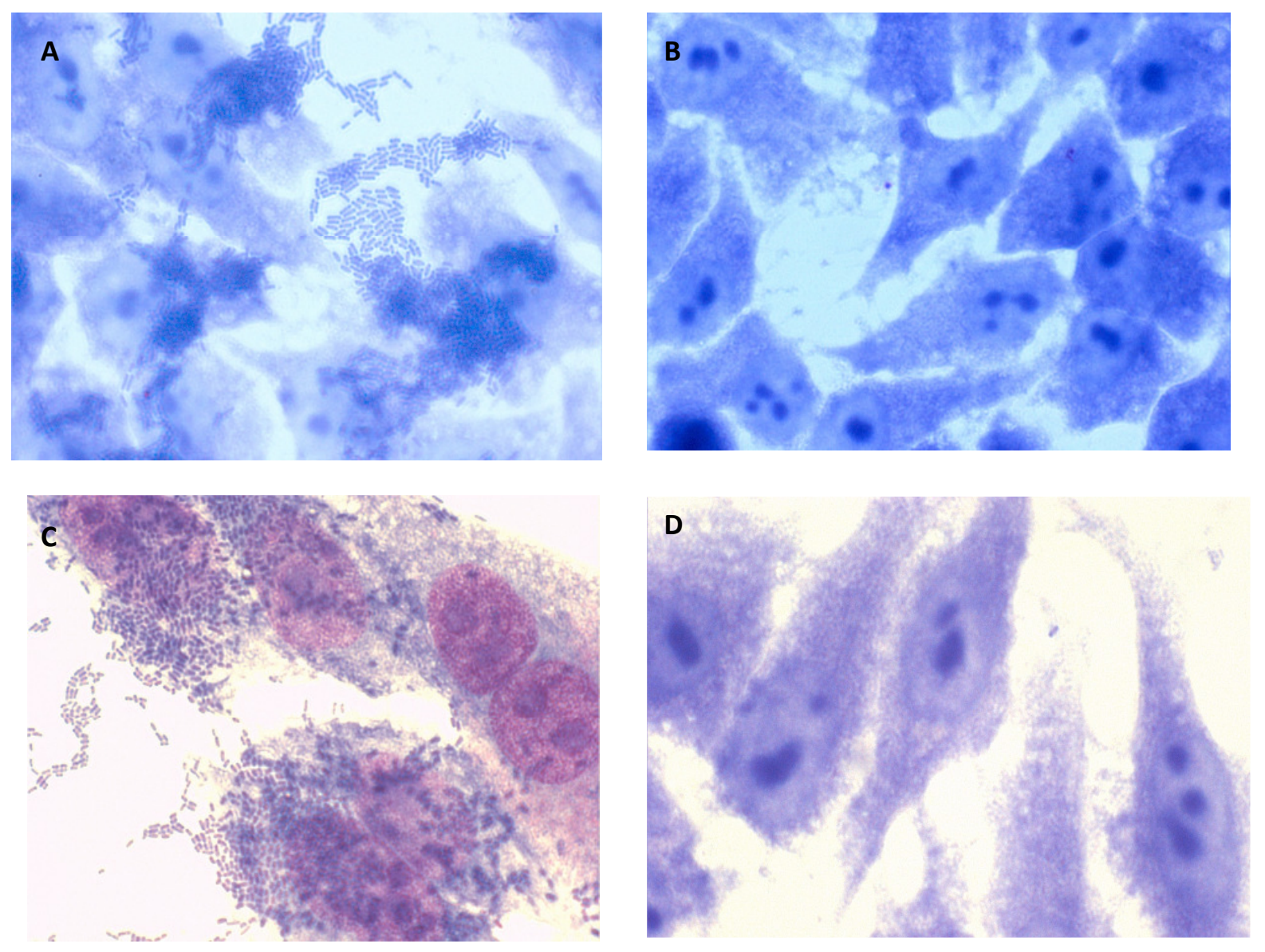

Figura 15- Padrão de interação das amostras de EAEC 042 (típica), 2871-1 (atípica) e de seus respectivos mutantes 042::pFV3 e 2871-1/Nal::pFV3 com células epiteliais HEp-2. As células foram coradas com solução de May-Grünwald/Giemsa. A, padrão agregativo de adesão da amostra 042 em ensaio de 3h; B, ausência de adesão da amostra mutante 042::pFV3 em ensaio de 3h; C, adesão agregativa da amostra 2871-1 em ensaio de 6h; D, ausência de adesão da amostra mutante 2871-1::pFV3 em ensaio de 6 h. Aumento de 1.000 vezes.

Em seguida, as amostras mutantes foram avaliadas quanto à capacidade de formar biofilme em superfície de poliestireno. A Figura 16 mostra o gráfico das absorbâncias obtidas das amostras selvagens e seus respectivos mutantes. Conforme se observa, a mutação em shf provocou uma redução acentuada na capacidade de formar biofilme nas duas amostras de EAEC típica e atípica. As absorbâncias de ambas as amostras mutantes foram semelhantes à determinada para a amostra utilizada como controle negativo no ensaio ( $E$. coli DH5a). 


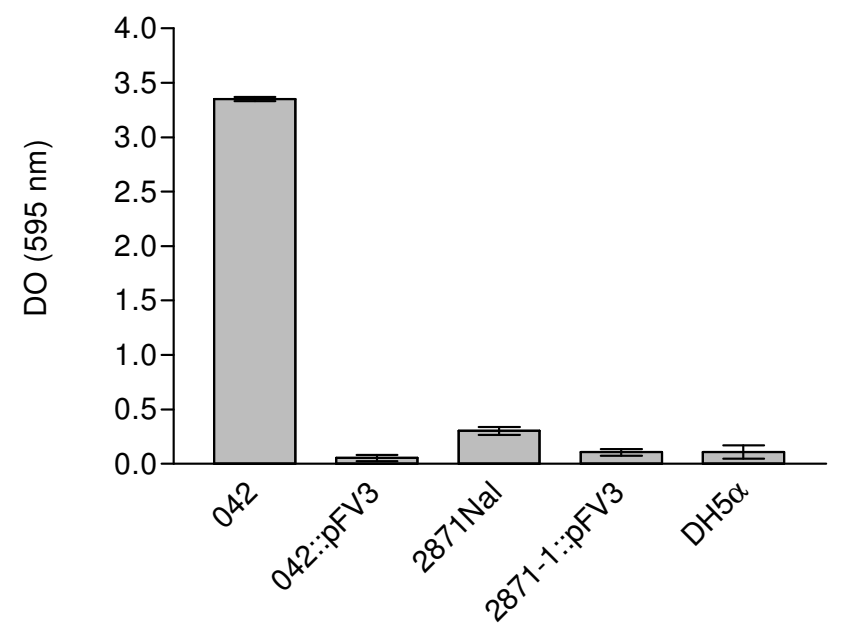

Amostras

Figura 16 - Capacidade de formação de biofilme em poliestireno apresentada pelas amostras de EAEC típica (042), atípica (2871-1) e de seus respectivos mutantes 042::pFV3 e 2871-1/Nal::pFV3. Gráfico das absorbâncias em comprimento de onda de $595 \mathrm{~nm}$ das suspensões de cristal violeta em etanol 95\%, correspondentes às colorações dos biofilmes formados nas placas de poliestireno após de incubação das bactérias em meio DMEM com 0,4\% de glicose a $37^{\circ} \mathrm{C}$ em condições estáticas por $24 \mathrm{~h}$. A amostra $E$. coli DH5a foi utilizada como controle negativo. 


\section{DISCUSSÃo}

Cerca de dois milhões de mortes devido à doença diarréica ocorrem no mundo anualmente (PETRI et al., 2008). A maior parte dos casos ocorre em crianças menores de cinco anos, faixa etária onde a diarréia aguda ainda é a segunda causa de mortalidade (JAFARI et al., 2009).

Os patótipos de ECD destacam-se como os agentes etiológicos bacterianos mais prevalentes das doenças diarréicas (CLARKE, 2001). Dentre esses patótipos está a EAEC, considerado um patógeno entérico emergente (BUERIS et al., 2007; FLORES; OKHUYSEN, 2009; HUANG et al., 2006; MORENO et al., 2008; NGUYEN et al., 2005; REGUA-MANGIA et al., 2004; ROBINS-BROWNE et al., 2004; RODRIGUES et al., 2002; SARANTUYA et al., 2004; SCALETSKY et al., 2002b; SVENUNGSSON et al., 2000).

Inúmeros estudos epidemiológicos sobre a etiologia da diarréia aguda e persistente na infância apontam EAEC como o patótipo de ECD mais prevalente (FLORES; OKHUYSEN, 2009; HUANG et al., 2006). De fato, Huang et al. (2006) demonstraram que EAEC está estatisticamente associada como agente de diarréia aguda e persistente em países desenvolvidos e em desenvolvimento, diarréia em pacientes com HIV, diarréia do viajante e surtos de diarréia em países desenvolvidos, através de uma meta-análise de todos artigos sobre o isolamento de EAEC publicados entre 1987 e 2006.

Vários potenciais fatores de virulência foram descritos em EAEC, mas a patogênese da diarréia causada por esse patótipo ainda não foi totalmente esclarecida (KAPER et al., 2004). A maioria desses fatores de virulência foi descrita na amostra protótipo 042, embora alguns deles tais como as adesinas AAF/I, AAF/III, pili tipo IV, Hda e Ap58, tenham sido identificados em outras amostras de EAEC (BOISEN et al., 2008; BERNIER et al., 2002; DUDLEY et al., 2006a; MONTEIRO-NETO et al., 2003; NATARO et al., 1992). Além disso, os fatores envolvidos com alguns mecanismos de virulência apresentados por algumas amostras de EAEC, tais como a invasão e a indução da secreção de muco e interleucinas, não são completamente conhecidos (FLORES; OKHUYSEN, 2009; STEINER et al., 1998; WEINTRAUB, 2007).

Alguns dos genes que codificam potenciais fatores de virulência de EAEC estão localizados em plasmídeos de alto peso molecular ( 100 kb), 
geralmente presentes em amostras desse patótipo (KAPER et al., 2004). Devido à associação desses plasmídeos com a expressão do padrão $A A$, eles foram denominados pAA (HARRINGTON et al., 2006).

Dentre as amostras de EAEC descritas na literatura, certamente a 042 é a mais conhecida e estudada. Ela foi isolada de uma criança com diarréia aguda em Lima (Peru), pertence ao sorotipo O44:H18 e foi a única cepa capaz de causar diarréia em voluntários humanos (NATARO et al., 1995; VIAL et al., 1988). Esse fato direcionou a essa amostra a maioria dos estudos sobre virulência de EAEC realizados na última década. O plasmídeo pAA2, bem como o genoma da 042 foram completamente seqüenciados (CZECZULIN et al., 1999; RASKO et al., 2008).

Alguns dos genes que codificam os potenciais fatores de virulência descritos na amostra protótipo 042 estão localizados no pAA2 e outros no cromossomo. Os genes encontrados no pAA2 são: aafABCD e aggR (codificam as proteínas envolvidas na biogênese da fímbria $A A F / I I)$, aatPABCD (codificam as proteínas envolvidas no sistema de secreção do tipo $A B C$ ), aap (codifica a proteína antiagregativa Dispersina), astA (codifica a toxina EAST) e pet (codifica a toxina Pet) (ELIAS et al., 1999; CZECZULIN et al., 1999; SHEIKH et al., 2002; NISHI et al., 2005).

Além dos genes descritos anteriormente, o seqüenciamento do plasmídeo de virulência pAA2 revelou um grupo de três genes (shf, capU e virk) entre o operon aatPABCDD e o gene aafC, denominado cap cluster (CZECZULIN et al., 1999). A proteína codificada por capU apresenta identidade com 0 produto de um gene relacionado a biossíntese do lipopolissacarídeo de E. coli O157:H7 (CZECZULIN et al., 1999), enquanto virk parece estar relacionado à regulação pós-transcricional de virG em Shigella flexneri (NAKATA et al., 1992). Por outro lado, Czeczulin et al. (1999) reportaram que o plasmídeo pAA2 não alberga o gene virG. Já o gene shf codifica uma proteína que apresenta homologia com IcaB de S. epidermidis, a qual participa da modificação da molécula de exopolissacarídeo envolvida na formação de biofilme e adesão intercelular (HEILMANN et al., 1996). O papel das proteínas codificadas por $c a p U$, virk e shf na patogênese de EAEC não é conhecido. 
Recentemente foi proposta uma subclassificação de EAEC nos grupos típica e atípica, com base na presença ou ausência do gene aggR, respectivamente (SARANTUYA et al., 2004). O gene aggR codifica uma proteína da família AraC de ativadores transcricionais e corresponde a um ativador global dos genes de virulência de EAEC (NATARO et al., 1994; HARRINGTON et al., 2006). Pelo menos os operons aaf e aai e os genes aap, aatA e pet são regulados por AggR, e o conjunto desses genes é conhecido como regulon AggR (HARRINGTON et al., 2006). Uma vez que a detecção de aggR está associada à presença dos plasmídeos pAA e, conseqüentemente, de vários potenciais fatores de virulência, foi sugerido que o subgrupo de EAEC típica apresente maior potencial de virulência (HARRINGTON et al., 2006; SARANTUYA et al., 2004)

O patótipo EAEC é muito heterogêneo com relação à prevalência dos diversos genes que codificam os marcadores de virulência, ou seja, nenhum gene ou grupo de genes de virulência está presente em todas as amostras de EAEC (HUANG et al., 2006). Isso indica que apenas um grupo de amostras de EAEC seja patogênico para o homem, porém as características desse grupo ainda não foram definidas.

Nos estudos em que a distribuição dos genes de virulência de EAEC foi pesquisada, shf aparece dentre os mais prevalentes (BOUZARI et al., 2005; CZECZULIN et al., 1999; ELIAS et al., 2002; JENKINS et al., 2006a; KAHALI et al., 2004; MOHAMED et al., 2007; REGUA-MANGIA et al., 2009; SUZART et al., 2001; ZAMBONI et al., 2004)

Embora esse gene seja detectado com freqüência em amostras de EAEC, a função da proteína Shf na patogênese não foi estabelecida. A homologia com a proteína IcaB de $S$. epidermidis (HEILMANN et al., 1996) sugere uma participação de Shf na formação de biofilme de EAEC, fenótipo descrito como multifatorial nesse patótipo (SHEIKH et al., 2001; MOREIRA et al., 2003; FUJIYAMA et al., 2008).

Desta forma, os principais objetivos deste estudo foram determinar a prevalência de shf em amostras de EAEC típicas e atípicas isoladas em nosso meio, caracterizar essas amostras e avaliar a eventual participação de Shf no estabelecimento dos fenótipos de adesão agregativa e de formação de biofilme em EAEC típica e atípica. 
Com o intuito de verificar a prevalência do gene shf em amostras isoladas em nosso meio, foram selecionas as 113 amostras de EAEC isoladas em um estudo epidemiológico sobre a etiologia da diarréia aguda na infância, realizado na cidade de Salvador (BA) durante os anos de 2003 e 2004. Nesse estudo, EAEC foi o enteropatógeno bacteriano mais prevalente e esteve estatisticamente associado à diarréia. Essas amostras foram identificadas com base na detecção do gene aat $A$, correspondente à sonda CVD432 ou sonda AA, e não pelo padrão AA em células epiteliais cultivadas (BUERIS et al., 2007).

No presente estudo, o gene shf foi detectado em 41 (39\%) amostras de EAEC isoladas em Salvador, desconsiderando a classificação dessas amostras nos subgrupos típica e atípica. Essa prevalência está de acordo com relatos anteriores sobre essa prevalência em EAEC sem classificação em típica ou atípica, onde foram mostradas altas prevalências do gene shf, com valores variando entre 17,6\% e 65,3\% (BOUZARI et al., 2005; CZECZULIN et al., 1999; ELIAS et al., 2002; JENKINS et al., 2006a; KAHALI et al., 2004; REGUA-MANGIA et al., 2009; ZAMBONI et al., 2004). Czeczulin et al. (1999) reportaram que a incidência do gene shf entre amostras de EAEC isoladas de diversos países foi de 50\%. Em outro estudo realizado por Kahali et al. (2004) na Índia, shf também foi detectado em alta prevalência (65,3\%). Esses dados demonstram que shf é um dos marcadores freqüentemente detectados em EAEC, embora a sua incidência seja menor que a de $a g g R$ e a da sonda CVD432 (aatA) (CZECZULIN et al., 1999; ELIAS et al., 2002; JENKINS et al., 2006a; KAHALI et al., 2004; REGUA-MANGIA et al., 2009; ZAMBONI et al., 2004).

Nos estudos realizados no Brasil, a prevalência do gene varia entre 27,9\% e 49,4\% (Elias et al., 2002; REGUA-MANGIA et al., 2009; ZAMBONI et al., 2004). Entretanto em um estudo realizado em Londrina (PR) esse gene não foi detectado nas amostras de EAEC selecionadas através do padrão AA em células HEp-2 (GIOPPO et al., 2000).

Embora prevalente em EAEC, shf também foi detectado em amostras de EHEC (CZECZULIN et al., 1999), EPEC atípica (GOMES et al., 2004; MOREIRA et al., 2008), E. coli uropatogênicas (ABE et al., 2008) e em amostras classificadas como não pertencentes ao patótipo EAEC (JENKINS et 
al., 2006a). Em amostras de EPEC atípicas do sorotipo O51:H40, shf foi o único marcador de virulência detectado em amostras capazes de causar a lesão A/E em alça ligada de coelho (MOREIRA et al., 2008). Além disso, Moreira (2001) demonstrou que o gene shf era o único marcador de virulência em EAEC do sorotipo 0128:H35 e que esse gene estava localizado no cromossomo dessas amostras e não em plasmídeos. O conjunto desses dados indicam que shf pode ser transferido entre amostras de diferentes patótipos e que essa transferência pode ocorrer entre plasmídeo e cromossomo através de eventos de transposição.

Uma vez determinada a prevalência de shf em EAEC, as amostras portadoras desse gene foram avaliadas com relação aos seus sorogrupos. Foram determinados 21 distintos sorogrupos dentre as 41 amostras, sendo que nenhum deles prevaleceu e em nove amostras $O$ antígeno $O$ não foi tipado. A grande diversidade de sorogrupos ou sorotipos em amostras de EAEC é uma característica amplamente demonstrada (CZECZULIN et al., 1999; JENKINS et al., 2006a; KAHALI et al., 2004; REGUA-MANGIA et al., 2009; PIVA et al., 2003; UBER et al., 2006; VIAL et al., 1988; ZAMBONI et al., 2004) e essa característica se manteve dentre as amostras shf deste estudo.

Essas mesmas amostras shf foram também analisadas quanto aos padrões de adesão em células HEp-2. Uma vez que todas foram previamente classificadas como EAEC, devido à reatividade com a sonda CVD432 (BUERIS et al., 2007), era esperado que todas apresentassem o padrão AA característico de EAEC. De fato, a maioria delas $(78,1 \%)$ apresentou o padrão AA nos ensaios de adesão de $6 \mathrm{~h}$. $\mathrm{O}$ restante das amostras apresentou 0 padrão $A D(7,3 \%)$ ou foram incapazes de aderir (14,6\%) em células HEp-2. Amostras reativas com a sonda CVD432 incapazes de aderir em células epiteliais cultivadas foram descritas por outros autores (GIOPPO et al., 2000). Essa incapacidade de aderir em células HEp-2 pode refletir a perda do fator que medeia essa adesão após o isolamento da amostra ou mesmo a falta de receptores para as adesinas na linhagem HEp-2, que não é de origem intestinal (NATARO; KAPER, 1998). Com relação às amostras que apresentaram o padrão $D A$, não há relatos na literatura sobre amostras de DAEC que hibridizem com a sonda CVD432. No entanto, há relatos mostrando que a sonda daaC empregada para o diagnóstico molecular de DAEC pode 
detectar amostras de EAEC em decorrência de reação cruzada entre o usher da fímbria F1845 (daaC) e outros ushers de fímbrias que medeiam o padrão AA (NATARO; KAPER, 1998).

As 41 amostras de EAEC em que shf foi detectado foram classificadas nos subgrupos de típica e atípica pela detecção do gene aggR (SARANTUYA et al., 2001). Dentre as 113 EAEC avaliadas 67 foram classificadas como típicas e 46 como atípicas. Dessa forma, o gene shf foi encontrado em 37,3\% das amostras de EAEC típicas e em $34,8 \%$ das EAEC atípicas. Isso demonstrou que shf esteve distribuído em porcentagens semelhantes em ambos os grupos. Não há relatos na literatura demonstrando a prevalência de shf em amostras previamente classificadas como EAEC típicas ou atípicas. Todavia, ao analisar os resultados publicados sobre a detecção de shf foi possível separar as amostras shft típicas e atípicas nos estudos em que a detecção de agg $R$ foi relatada. Na maioria desses trabalhos as prevalências de shf nos dois grupos foram bastante semelhantes, variando entre $16 \%$ e 55,2\% (CZECZULIN et al., 1999; REGUA-MANGIA et al., 2009; ZAMBONI et al., 2004). Essa distribuição semelhante não foi encontrada por Elias et al. (2002) onde shf foi detectado em $52,8 \%$ das EAEC aggR ${ }^{+}$e em $16 \%$ das aggR. Entretanto a amostragem de EAEC aggR analisada nesse estudo foi pequena, incluindo somente 12 amostras.

$O$ fato de amostras de EAEC atípica albergarem shf em alta prevalência indica que esse gene não está sob a regulação de AggR, considerando que realmente ocorre a sua expressão nessas amostras.

As 41 amostras de EAEC shf', também foram pesquisadas quanto à capacidade de formação de biofilme em superfície de poliestireno. A análise empregada demonstrou que todas foram capazes de formar biofilme. Oito amostras formaram biofilme menos densos, ou seja, com absorbância abaixo de 1,0 (quatro delas típicas e quatro atípicas). Outras quatro amostras foram capazes de formar biofilme muito densos, acima do valor de absorbância da amostra protótipo 042 , sendo que uma delas era atípica. Isso demonstra que a capacidade de formar biofilme foi independente da presença ou ausência de aggR, ou seja, independente da caracterização em típica ou atípica. Isso difere de alguns relatos da literatura, onde aggR foi descrito como envolvido na formação de biofilme em EAEC (MOHAMED et al., 2007; WAKIMOTO et al., 
2004). Devido à característica multifatorial da formação de biofilme em EAEC, a presença de outros genes associados a esse fenótipo, tais como fis, yafK, aafA e fimA (SHEIKH et al., 2001; MOREIRA et al., 2003), precisa ser pesquisada nas amostras do presente estudo para melhor compreensão da capacidade de formação de biofilme.

Outro aspecto bastante interessante é o fato de que amostras não aderentes tenham sido capazes de formar biofilme, uma vez que o primeiro passo para a sua formação em EAEC seria a adesão no padrão agregativo. Entre as 41 amostras $s h f^{+}$, seis foram incapazes de aderir e três aderiram no padrão difuso em células HEp-2. No ensaio de formação de biofilme, essas nove amostras foram capazes de formar biofilme. No entanto, dentre as amostras capazes de formar biofilmes mais densos, todas foram apresentaram o padrão AA. Uma possível explicação para o fato de amostras não aderentes formarem biofilme em poliestireno seria o fato da presença de manose no ensaio de adesão, enquanto nos ensaios de biofilme a manose não é utilizada. Sabe-se que a fímbria tipo 1 é inibida pela manose e, portanto, uma amostra não aderente poderia ser capaz de formar biofilme com a participação dessa fímbria (CONNELL et al., 1996; JOHNSON, 1991; MOREIRA et al., 2003). Dessa forma, a análise da interação dessas amostras com células HEp-2 na ausência de manose merece ser investigada.

A fímbria do tipo I é a adesina mais comum encontrada em enterobactérias, e é usualmente observada em E. coli patogênicas e comensais, sendo sensível a resíduos de manose (CONNELL et al., 1996). Essa fímbria codificada pelo operon fim é relatada como responsável pelo estabelecimento inicial da adesão em amostras de E. coli K12 e importante fator de virulência em E. coli uropatogênica (CONNELL et al., 1996; JOHNSON, 1991). Amostras de EAEC mutantes em fimD, gene que codifica o usher da fímbria tipo I, apresentaram uma inibição no padrão AA de $80 \%$ e na formação de biofilme de $49 \%$, demonstrando a importância dessa fímbria no estabelecimento desses fenótipos (MOREIRA et al., 2003).

A segunda etapa do presente estudo consistiu na obtenção de mutantes em shf em uma amostra de cada subgrupo de EAEC, ou seja, em uma amostra típica e em uma atípica. Para isso foram selecionadas como protótipo as amostras 042 (típica) e 2871-1 (atípica). 
A amostra 2871-1 foi isolada na cidade de São Paulo de um caso de diarréia aguda em uma criança e pertence ao sorotipo O4:H33 (GOMES et al., 1998; UBER et al., 2006). Essa amostra foi descrita como portadora apenas do gene shf (ELIAS et al., 2002). Após essa caracterização genética, outros novos fatores de virulência de EAEC foram descritos e por esse motivo a presença desses fatores foi avaliada no presente estudo. Foram pesquisados os genes da biogênese da fímbria AAF/III (aag3A e agg3C), da principal subunidade do pili do tipo IV de EAEC (pilS), do operon aai da ilha de patogenicidade de EAEC (aaiA) e dos outros dois genes do cap cluster (virk e capU) (BERNIER et al., 2002; CZECZULIN et al., 1999). A complementação dessa análise mostrou que essa amostra apresenta também os genes capU e virK, ou seja, o cap cluster está presente nessa amostra. Como essa amostra é desprovida de aggR, isso a caracteriza como uma EAEC atípica que alberga apenas o cap cluster, dentre os fatores de virulência de EAEC descritos até o presente momento.

Cabe salientar o fato de que a amostra 2871-1, desprovida de quase todos marcadores de virulência descritos em EAEC, apresenta o cap cluster íntegro. Isso sugere que esses três genes sejam transferidos em conjunto, embora não haja evidências de que correspondam a um operon. Além disso, os genes capU e virk não foram considerados diretamente envolvidos na formação de biofilme da amostra 042 (FUJIYAMA et al., 2008).

A mutagênese realizada nas duas amostras selecionadas foi do tipo não-polar, ou seja, a transcrição dos genes capU e virK, localizados à jusante de shf, não foi afetada. O efeito da mutação em shf nessas duas amostras foi avaliado nos fenótipos de adesão à células epiteliais e de formação de biofilme em poliestireno.

O ensaio de adesão em células HEp-2 mostrou uma inibição total da adesão de ambas as amostras mutantes, tanto em $3 \mathrm{~h}$ como em $6 \mathrm{~h}$ de interação bactérias-células epiteliais. Embora EAEC possua várias adesinas responsáveis pela adesão a células epiteliais, esses dados sugerem que o produto de shf tenha um papel importante na interação celular desse patótipo. Esse achado é interessante considerando-se que a amostra 042 expressa a fímbria AAF/II, descrita como responsável pelo seu padrão AA (CZECZULIN et al., 1997), ao passo que a amostra 2871-1 não apresenta os genes das 
fímbrias AAF/I, II e III., De forma não estabelecida, a proteína Shf participa de alguma etapa no processo de adesão e a sua ausência interfere com o processo de interação de AAF/II com as células epiteliais na amostra típica. $\mathrm{Na}$ amostra atípica a presença de uma adesina não conhecida não pode ser descartada e Shf poderia interagir de alguma forma também com essa adesina. A participação de Shf poderia estar também relacionada à síntese de exopolissacarídeos importantes na formação de biofilme em ambos subgrupos de EAEC.

Os achados relatados no presente estudo com relação à mutação em shf da amostra 042 se confrontam com os dados obtidos por Fujiyama et al. (2008), onde a mutação não causou significativa modificação no padrão de adesão entre a amostra selvagem e a mutante. Contudo, esses autores não apresentaram uma figura mostrando o padrão de adesão da amostra mutante. Embora em desacordo com os dados obtidos por esses autores, os resultados relatados no presente estudo foram confirmados em diferentes ensaios realizados sempre em triplicatas.

Cabe aqui salientar, que o presente projeto de pesquisa foi iniciado em 2005, anteriormente à publicação do artigo de Fujiyama et al. (2008), que relatou o nocaute no cap cluster da amostra 042. Os objetivos apresentados em nosso estudo eram originais no momento de sua elaboração e a análise da mutação em shf em uma EAEC atípica não ainda foi descrita na literatura.

Após a verificação do efeito do nocaute em shf na adesão em células epiteliais, foi analisado o efeito dessa mutação na capacidade de formação de biofilme. Novamente foi constatada uma significativa diminuição da capacidade de formação de biofilme nessas amostras mutantes em relação às amostras selvagens.

A capacidade de EAEC em formar biofilme in vivo foi descrita em cultura de biópsia de cólon humano e sugere uma relação com a persistência da diarréia ( HICKS et al., 1996; SHEIKH et al., 2001). A participação da fímbria AAF/II e das proteínas Fis e YafK na formação desse biofilme de EAEC foi descrita por Sheikh et al. (2001), utilizando a amostra protótipo 042 cultivada em meio de cultura celular rico em glicose. A proteína Fis está envolvida na transcrição dependente da fase de crescimento e YafK é uma proteína hipotética necessária para a expressão de AAF/II (SHEIKH et al., 
2001). Nenhum dos mutantes que perderam a capacidade de formar biofilme apresentou inserção em shf no estudo de Sheikh et al. (2001). Além de Fis e YafK, o envolvimento da fímbria tipo I no fenótipo de formação de biofilme em EAEC foi evidenciado por Moreira et al. (2003).

Tomando por base a função de IcaB em $S$. epidermidis, a única proteína que apresenta homologia com Shf, pode-se sugerir seu papel na formação de exopolissacarídeos, fundamentais para o estabelecimento de biofilmes e conseqüentemente para a adesão agregativa de EAEC (CZECZULIN et al., 1999; HEILMANN et al., 1996; VUONG et al., 2004).

A produção de uma mistura extracelular de polímeros de açúcar denominados exopolissacarídeos é crítica para a formação de biofilmes bacterianos, sendo o principal componente da sua matriz (WATNICK, KOLTER, 2000). Estudos demonstraram que a proteína IcaB é responsável pela desacetilação da molécula poli-N-acetilglucosamina, formando uma molécula exopolissacarídica presente em muitos microrganismos, e que participa da formação do biofilme (VUONG et al., 2004).

A produção de polímeros de açúcar que irão formar a camada de exopolissacarídeo, a qual é característica e crítica para a formação do biofilme, possui função importante na capacidade de evasão do sistema imune e à tolerância a agentes antibacterianos (HEILMANN et al., 1996; VUONG et al., 2004).

Em nosso estudo, pôde-se observar que as amostras típica e atípica mutadas no gene shf, apresentaram uma baixa capacidade de formação de biofilme, porém também houve a inibição da sua capacidade de adesão em células HEp-2.

Fujiyama et al. (2008) analisaram a função do cap cluster na amostra de EAEC 042 através do nocaute desses genes e avaliaram, através de ensaio de agregação em meio líquido e em células HEp-2, e de formação de biofilme, os efeitos desses nocautes. Todos os mutantes mantiveram a capacidade de agregar, porém o mutante do gene shf foi o único que sofreu uma diminuição significativa na capacidade de formação de biofilme. Além disso, esses autores descreveram que shf está sob o controle transcricional de AggR. Esses autores sugerem que shf não está relacionado à agregação na fase líquida do biofilme e na sua adesão na fase inicial, mas que pode ter uma 
função na adesão intercelular na fase de maturação do biofilme, de uma maneira similar ao que ocorre com IcaB.

Um dado interessante é o fato da amostra 2871-1, EAEC atípica que apresenta apenas o cap cluster, apresentar resultados bastante semelhantes ao da amostra 042 que apresenta um repertório genético de fatores de virulência bastante distinto. Tanto o mutante da amostra 042 quanto da 2871-1 apresentaram total redução da adesão e da capacidade de formação de biofilme. Isso indica que a expressão do gene shf na amostra 2871-1 não está sob o controle do gene aggR, regulador global dos genes de virulência de EAEC. Esses dados divergem dos resultados obtidos por Fujiyama et al. (2008), mostrando que o gene shf está sob o controle transcricional de AggR na amostra protótipo 042. Essa conclusão foi obtida por esses autores a partir do resultado em um experimento de de RT-PCR para shf empregando uma amostra mutante no gene aggR (042::aggR). Esses autores relatam que a transcrição do gene shf foi abolida nesse mutante. Porém, ao analisar os resultados mostrados observa-se que a expressão de shf não é totalmente nula e sim nitidamente diminuída.

Partindo do princípio que AggR é o regulador global dos fatores de virulência plasmidiais e cromossômicos em EAEC, Mohamed et al. (2007) pesquisaram a habilidade de formar biofilme em isolados que carregavam outros genes como aap, astA, irp-2, pet, setA, shf e aatA, em amostras típicas e atípicas e constataram que, as que possuíam agg $R$ eram maiores produtoras de biofilme, sugerindo assim que aggR regula também outros genes necessários para a formação de biofilme em EAEC. Algumas amostras agregativas, que não possuíam nenhum dos genes pesquisados, produziram biofilme. Este dado é um indício de que fatores adicionais estão envolvidos na produção de biofilme em EAEC.

EAEC vem sendo cada vez mais relacionada como um grupo de patógenos emergentes, devido à sua associação com diarréia aguda e persistente, tanto em países em desenvolvimento como em desenvolvidos (FLORES; OKHUYSEN, 2009; HUANG et al., 2006; OKEKE, NATARO; 2001; WEINTRAUB, 2007).

Todos os estudos até hoje realizados, juntamente como os resultados obtidos neste trabalho, demonstram que os vários potenciais fatores de 
virulência de EAEC estão distribuídos heterogeneamente entre as amostras desse patótipo. Entre esses fatores, destaca-se o gene shf que é bastante prevalente e parece ser um importante marcador de virulência para esse patótipo. Os dados obtidos no presente trabalho demonstram que o produto de shf está envolvido nos fenótipos de adesão agregativa e na capacidade de formação de biofilme, tanto em EAEC típica quanto em atípica. Entretanto, alguns pontos com relação à participação da proteína Shf nesses fenótipos necessitam ser esclarecidos, como por exemplo a sua localização celular. $\mathrm{Na}$ continuidade deste projeto, um clone que expressa a proteína Shf recombinante foi obtido em nosso laboratório e a produção de um antissoro poderá responder a essa questão, bem como avaliar se as amostras de EAEC atípicas realmente expressam essa proteína. 


\section{CONCLUSÕES}

O gene shf foi encontrado em alta prevalência em EAEC típicas e atípicas isoladas de crianças com diarréia aguda em nosso país, e não houve diferenças entre as prevalências nesses dois grupos de EAEC.

As características de adesão em células HEp-2, sorogrupos e capacidade de formação de biofilme apresentadas pelas amostras que albergam o gene shf foram semelhantes nos grupos de EAEC típica e atípica.

O produto do gene shf está envolvido nos fenótipos de adesão agregativa e na capacidade de formação de biofilme em EAEC típica (amostra 042) e atípica (amostra 2871-1).

$\mathrm{Na}$ amostra de EAEC atípica 2871-1 o gene shf não é regulado pelo produto do gene aggR. 


\section{REFERÊNCIAS BIBLIOGRÁFICAS}

ABE, C. M.; KNUTTON, S.; PEDROSO, M. Z.; FREYMÜLLER, E.; GOMES, T. A. T. An enteroaggregative Escherichia coli strain of serotype O111:H12 damages and invades cultured T84 cells and human colonic mucosa. FEMS Microbiol. Lett., v. 203, p. 199-205, 2001.

ABE, C. M.; SALVADOR, F. A.; FALSETTI, I. N.; VIEIRA, M. A. M.; BLANCO, J.; BLANCO, J. E.; BLANCO, M.; MACHADO, A. M. O.; ELIAS, W. P.; HERNANDES, R. T.; GOMES, T. A. T. Uropathogenic Escherichia coli (UPEC) strains may carry virulence properties of diarrhoeagenic Escherichia coli. FEMS Microbiol. Lett., v. 52, p. 397-406, 2008.

ADACHI, J. A.; ERICSSON, C. D.; JIANG, Z. D.; DUPONT, M. W.; PALLEGAR, S. R.; DUPONT, H. I. Natural history of enteroaggregative and enterotoxigenic Escherichia coli infection among US travelers to Guadalajara, Mexico. J. Infect. Dis., v. 185, p. 1681-1683, 2002.

ADACHI, J. A.; JIANG, Z.D.; MATHEWSON, J. J.; VERENKAR, M. P.; THOMPSON, S.; MARTINEZ-SANDOVAL, F.; STEFFEN, R.; ERICSSON, C. D.; DUPONT, H. L. Enteroaggregative Escherichia coli as a major etiologic agent in traveler's diarrhea in 3 regions of the world. Clin. Infect. Dis., v. 32, p. 1706-9, 2001.

ALBERT, M. J.; QUADRI, F.; HAQUE, A.; BHUIYAN, N. A. Bacterial clump formation at the surface of liquid culture as a rapid test for identification of enteroaggregative Escherichia coli. J. Clin. Microbiol., v. 31, p. 1387-1399, 1993.

AL-HASANI, K.; RAJAKUMAR, K.; BULACH, D.; ROBINS-BROWNE, R.; ADLER, B.; SAKELLARIS, $H$. genetic organization of the she pathogenicity island in Shigella flexneri 2a. Microb. Pathog., v. 30, p. 1-8, 2001.

BAUDRY, B.; SAVARINO, S. J.; VIAL, P.; KAPER, J. B.; LEVINE, M. M. A sensitive and specific DNA probe to identify enteroaggregative Escherichia coli, a recently discovered diarrheal pathogen. J. Infect. Dis., v. 161, p. 1249-1251, 1990.

BENJAMIM, P.; FEDERMAN, M.; WANKE, C. A. Characterization of an invasive phenotype associated with enteroaggregative Escherichia coli. Infect. Immun., v. 63, p. 3417-3421, 1995.

\footnotetext{
"De acordo com:

ASSOCIAÇÃO BRASILEIRA DE NORMAS TÉCNICAS. NBR 6023: Informação e documentação: referências: elaboração. Rio de Janeiro, 2002.
} 
BERNIER, C.; GOUNON, P.; LE BOUGUÉNEC, C. Identification of an aggregative adhesion fimbria (AAF) type III-encoding operon in enteroaggregative Escherichia coli as a sensitive probe for detecting the AAFencoding operon family. Infect. Immun., v. 70, p. 4302-4311, 2002.

BHAN, M.K.; BHATNAGAR, S. Persistent diarrhea in infants and young children. Indian Pediatr., v. 30, p. 147-151, 1994.

BHAN, M.K.; RAJ, P.; LEVINE, M.M.; KAPER, J.B.; BHANDARI, N.; SRIVASTAVA, R.; KUMAR, R.; SAZAWAL, S. Enteroaggregative Escherichia coli associated with persistent diarrhea in a cohort of rural children in India. J. Infect. Dis., v. 159, p. 1061-1064, 1989.

BHATNAGAR, S.; BHAN, M. K.; SOMMERFELT, H.; SAZAWAL, S.; KUMAR, R.; SAINI, S. Enteroaggregative Escherichia coli may be a new pathogen causing acute and persistent diarrhea. Scand. J. Infec. Dis., v. 25, p. 579-583, 1993.

BOISEN, N.; STRUVE, C.; SCHEUTZ, F.; KROGFELT, K. A.; NATARO, J. P. New adhesin of enteroaggregative Escherichia coli related to the Afa/Dr/AAF family. Infect. Immun., v. 76, p. 3281-3292, 2008.

BOOP, C. A.; BRENNER, F. W.; WELLS, J. G.; STROCKBINE, N. A. Escherichia, Shigella and Salmonella. In: MURRAY, P. R.; BARON, E. J.; PFALLER, M. A.; TENOVER, F. C.; YOLKEN, R. H. (Ed.). Manual of clinical microbiology . 7. ed. Washington, D. C.: ASM Press, 1999. Cap. 28, p. 459465.

BOUZARI, S.; JAFARI, A.; FARHOUDI-MOGHADDAM, A A..; SHOKOUHI, F.; PARSI, M. Adherence of non-enteropathogenic Escherichia coli to HeLa cells. J. Med. Microbiol., v. 40, p. 95-97, 1994.

BOUZARI, S.; JAFARI, A.; ZAREPOUR, M. Distribution of virulence related genes among enteroaggregative Escherichia coli isolates: using multiplex PCR and hybridization. Infect. Genet. Evol., v. 5, p. 79-83, 2005.

BUERIS, V.; SIRCILI, M. P.; TADDEI, C. R.; SANTOS, M. F.; FRANZOLIN, M. R.; MARTINEZ, M. B.; FERRER, S. R.; BARRETO, M. L.; TRABULSI, L. R. Detection of diarrheagenic Escherichia coli from children with and without diarrhea in Salvador, Bahia, Brazil. Mem. Inst. Oswaldo Cruz, v.7, p.839-44, 2007.

CERNA, J.F.; NATARO, J.P.; ESTRADA-GARCIA, T. Multiplex PCR for detection of three plasmid-borne genes of enteroaggregative Escherichia coli strains. J. Clin. Microbiol., v. 41, p. 2138-2140, 2003.

CHART, H.; SMITH, H. R.; ROWE, B. Enteroaggregative strains of Escherichia coli belonging to serotypes $0126: \mathrm{H} 27$ e $\mathrm{O} 44: \mathrm{H} 18$ express antigenically similar $18 \mathrm{kDa}$ outer membrane-associated proteins. FEMS microbial. Lett., v. 132, p. 17-22, 1995. 
CHEN, H. D.; FRANKEL, G. Enteropathogenic Escherichia coli: unraveling pathogenesis. FEMS Microbiol. Rev., v.29, p. 83-98, 2005.

CLARKE, S. C. Diarrhoeagenic Escherichia coli - an emergin problem? Diagn. Infect. Dis., v. 41, p. 93-98, 2001.

COHEN, M. B.; NATARO, J. P.; BERNSTEIN, D. I.; HAWKINS, J.; ROBERTS, N.; STAAT, M. A. Prevalence of diarrheagenic Escherichia coli in acute childhood enteritis: a prospective controlled study. J. Pediatr., v. 146, p. 54-61, 2005.

COSTERTON, J. W. Introduction to biofilm. Int. J. Antimicrob. Agents, v. 11, p. 217-21, 1999.

COBELJIC, M.; MILJKOVIC-SELIMOVIC, B.; PAUNOVIC-TODOSIJEVIC, D.; VELICKOVIC, Z.; LEPSANOVIC, Z.; ZEC, N.; SAVIC, D.; ILIC, R.; KONSTANTINOVIC, S.; JOVANOVIC, B.; KOSTIC, V. Enteroaggregative Escherichia coli associated with an outbreak of diarrhea in a neonatal nursery ward. Epidemiol. Infect., v. 117, p. 11-16, 1996.

CONNELL, I.; AGACE, W.; KLEMM, P.; SCHEMBRI, M.; MARILD, S.; SVANBORG, C. Type I fimbrial expression enhances Escherichia coli virulence for the urinary tract. Proc. Natl. Acad. Sci. USA, v. 93, p. 9827-9832, 1996.

CORDEIRO, F.; PEREIRA, D. S. G.; ROCHA, M.; ASENSI, M. D.; ELIAS, W. P.; CAMPOS, L. C. Evaluation of a multiplex PCR for identification of enteroaggregative Escherichia coli. J. Clin. Microbiol., v. 46, p. 828-829, 2008.

CRAVIOTO, A.; GROSS, R. J.; SCOTLAND, S. M.; ROWE, B. An adhesive factor in strains of Escherichia coli belonging to the traditional infantile enteropathogenic serotypes. Curr. Microbiol., v. 3, p. 95-99, 1979.

CRAVIOTO, A.; TELLO, A.; NAVARRO, A.; RUIZ, J.; VILLAFÁN, H.; URIBE, F.; ESLAVA, C. Association of Escherichia coli HEp-2 adherence patterns with type and duration of diarrhoea. Lancet, v. 337, p. 262-264, 1991.

CZECZULIN, J. R.; BALEPUR, S.; HICKS, S.; PHILLIPS, A.; HALL, R.; KOTHARY, M. H.; NAVARRO-GARCIA, F.; NATARO, J. P. aggregative adherence fimbria II, a second fimbrial antigen mediating aggregative adherence in enteroaggregative Escherichia coli. Infect. Immun., v. 65, p. 4135-4145, 1997.

CZECZULIN, J. R.; WHITTAM, T. S.; HENDERSON, I. R.; NAVARRO-GARCIA, F.; NATARO, J. P. Phylogenetic analysis of enteroaggregative and diffusely adherent Escherichia coli. Infect. Immun., v. 67, p. 2692-2699, 1999.

DEBROY, C.; YEALY, J.; WILSON, R. A.; BHAN, M. K.; KUMAR, R. Antibodies raised against the outer membrane protein interrupt adherence of enteroaggregative Escherichia coli. Infect. Immun., v. 63, p. 2873-2879, 1995. 
DONLAN, R. M. Biofilms: microbial life on surfaces Emerg. Infect. Dis., v. 8, p. 881-90, 2002.

DONLAN; R. M.; COSTERTON, J. W. Biofilms: survival mechanisms of clinically relevant microorganisms. Clin. Microbiol. Rev., v. 15, p. 167-92, 2002.

DUDLEY, E. G.; ABE, C.; GHIGO, J. M.; LATOUR-LAMBERT; HORMAZABAL, J. C.; NATARO, J. P. An Incl1 plasmid contributes to the adherence of the atypical enteroaggregative Escherichia coli strain C1096 to cultured cells and abiotic surfaces. Infect. Immun., v. 74, p. 2102-2114, 2006a.

DUDLEY, E. G; THOMSON, N. R.; PARKHILL, J.; MORIN, N. P.; NATARO, J. $P$. Proteomic and microarray characterization of the AggR regulon identifies a pheU pathogenicity island in enteroaggregative Escherichia coli. Mol. Microbiol., v. 61; p. 1267-82, 2006b.

DURRER, P.; ZBINDEN, R.; FLEISCH, F.; ALTWEGG, M.; LEDERGERBER, B.; KARCH, H.; WEBER, R. Intestinal infection due to enteroaggregative Escherichia coli among human immunodeficiency virus- infected persons. J. Infect. Dis., v. 182, p. 1540-1544, 2000.

ELIAS, W. P.; CZECZULIN, J. R.; HENDERSON, I. R.; TRABULSI, L. R.; NATARO, J. P. Organization of biogenesis genes for aggregative adherence fímbria II (AAF/II) defines a virulence gene cluster in enteroaggregative Escherichia coli. J. Bacteriol., v. 181, p. 1779-1785, 1999.

ELIAS, W.P.; UBER, A.P.; TOMITA, S.K.; TRABULSI, L.R.; GOMES, T.A.T. Combinations of putative virulence markers in typical and variant enteroaggregative Escherichia coli strains from children with and without diarrhoea. Epidemiol. Infect., v.129, p.49-55, 2002.

ESLAVA, C.; NAVARRO-GARCIA, F.; CZECZULIN, J. R.; HENDERSON, I. R.; CRAVIOTO, A.; NATARO, J. P. Pet, an autotransporter enterotoxin from enteroaggregative Escherichia coli. Infect. Immun., v. 66, p. 3155-3163, 1998.

EWING, W. H. Edwards and Ewing's identification of Enterobacteriaceae. 4 ed. New York: Elsevier Publishing, 1986. 536 p.

FANG, G. D.; LIMA, A. A. M.; MARTINS, C. V.; NATARO, J. P.; GUERRANT, R. L. Etiology and epidemiology of persistent diarrhea in northeastern Brazil: a hospital-based, prospective, case-control study. J. Pediatr. Gastroenterol. Nutr., v. 21, p. 137-144, 1995.

FARUQUE, S. M.; HAIDER, K.; ALBERT, M. J.; AHMAD, Q. S.; ALAM, A. N.; NAHAR, S.; TZIPORI, S. A comparative study of specific gene probes and standard bioassays to identify diarrhoeagenic Escherichia coli in pediatric patients with diarrhoea in Bangladesh. J. Med. Microbiol., v. 36, p. 37-40, 1992. 
FASANO, A.; NORIEGA, F. R.; MANEVAL, D. R. JR.; CHANASONGCRAM, S.; RUSSEL, R.; GUANDALINI, S.; LEVINE, M. M. Shigella enterotoxin 1: an enterotoxin of Shigella flexneri 2 a active in rabbit small intestine in vivo and in vitro. J. Clin. Invest., v. 95, p. 2853-2861, 1995.

FOLKESSON, A.; LOFDAHL, S.; NORMARK, S. The Salmonella enterica subspecies I specific centisome 7 genomic island encodes novel protein families present in bacteria living in close contact with eukaryotic cells. Res. Microbiol., v.153, p. 537-545, 2002.

FLORES, J.; OKHUYSEN, P.C. Enteroaggregative Escherichia coli infection. Curr. Opin. Gastroenterol., v. 25, p. 8-11, 2009.

FRANKEL, G.; PHILLIPS, A. D.; ROSENSHINE, I.; DOUGAN, G.; KAPER, J. B.; KNUTTON, S. Enteropathogenic and enterohaemorragic Escherichia coli: more subversives elements. Mol. Microbiol., v. 30, p. 911-921, 1998.

FUJIYAMA, R.; NISHI, J.; IMUTA, N.; TOKUDA, K.; MANAGO, K.; KAWANO, $\mathrm{Y}$. The shf gene of a Shigella flexneri homologue on the virulent plasmid pAA2 of enteroaggregative Escherichia coli 042 is required for biofilm formation. Curr. Microbiol., v. 56, p. 474-480, 2008.

GASCÓN, J.; VARGAS, M.; QUINTÓ, L.; CORACHÁN, M.; JIMENEZ DE ANTA, M.T.; VILA, J. Enteroaggregative Escherichia coli strains as a cause of traveler's diarrhea: a case-control study. J. Infect. Dis., v. 177, p. 1409-12, 1998.

GERMANI, Y.; MINSSSART, P.; VOHITO, M.; YASSIBANDA, S.; GLAZIOU, P.; HOCQUET, D.; BERTHÉLÉMY, P.; MORVAN, J. Etiologies of acute, persistent, and dysenteric diarrheas in adults in Bangui, Central African Republic, in relation to human immunodeficiency virus serostatus. Am. J. Trop. Med. Hyg., v. 59 , p. $1008-1014,1998$.

GIOPPO, N. M. R.; ELIAS, W. P.; VIDOTTO, M. C.; LINHARES, R. E.; SARIDAKIS, H. O.; GOMES, T. A. T.; TRABULSI, L. R.; PELAYO, J. S. Prevalence of HEp-2 cell-adherent Escherichia coli and characterization of enteroaggregative $E$. coli and chain-like adherent $E$. coli isolated from children with and without diarrhoea, in Londrina, Brazil. FEMS Microbiol. Lett., v. 190, p. 293-298, 2000.

GIRÓN, J. A.; JONES, T.; MILLÁN-VELASCO, F.; CASTRO-MUNOZ, E.; ZARATE, L.; FRY, J.; FRANKEL, G.; MOSELEY, S. L.; BAUDRY, B.; KAPER, J. B.; SCHOOLNIK, G. K.; RILEY, L. W. Diffuse-adhering Escherichia coli (DAEC) as a putative cause of diarrhea in Mayan children in Mexico. J. Infect. Dis., v. 163, p. 507-513, 1991.

GOMES, T. A.; ABE, C. M.; MARQUES, L. R. Detection of HeLa cell-detaching activity and alpha-hemolysin production in enteroaggregative Escherichia coli strains isolated from feces of Brazilian children. J. Clin. Microbiol., v. 33, p. 3364, 1995. 
GOMES, T. A. T.; IRINO, K.; GIRÃO, D. M.; GIRÃO, V. B. C.; GUTH, B. E. C.; VAZ, T. M. I.; MOREIRA, F. C.; CHINARELLI, S. H.; VIEIRA, M. A. M. Emerging enteropathogenic Escherichia coli strains? Emerg. Infect. Dis., v. 10, p. 18511855, 2004.

GOMES, T. A. T.; VIEIRA, M. A. M.; ABE, C. M.; RODRIGUES, D.; GRIFFIN, P. M.; RAMOS, S. R. T. S. Adherence patterns and adherence-related DNA sequences in Escherichia coli isolates from children with and without diarrhea in São Paulo city, Brazil. J. Clin. Microbiol., v. 36, p. 3609-3613, 1998.

GOMES, T. A.; VIEIRA, M. A.; WACHSMUTH, I. K.; BLAKE, P. A.; TRABULSI, L. R. Serotype-specific prevalence of Escherichia coli strains with EPEC adherence factor genes in infants with and without diarrhea in São Paulo, Brazil. J. Infect. Dis., v. 160, p. 131-135, 1989.

GONZÁLES, R.; DIAZ, C.; MARINO, M.; CLORALT, R.; PEQUENESE, M.; PEREZ-SCHAEL, I. Age-specific prevalence of Escherichia coli with localized and aggregative adherence in Venezuelan infants with acute diarrhea. J. Clin. Microbiol., v. 35, p. 1103-1107, 1997.

GUARNER, F.; MELAGELADA, J. R. Gut flora in health and disease. Lancet, v. 360, p. 512-519, 2003.

GUINÉE, P. A. M.; JANSEN, W. H.; WADSTRÖM, T.; SELLWOOD, R Escherichia coli associated with neonatal diarrhoea in piglets and calves. In: LEEUW, P. W.; GUINÈE, P.A.M. (Ed.). Laboratory diagnosis in neonatal calf and pig diarrhea: Current topics in veterinary and animal science. The Netherland: Martinus Nijhoff Publishers, 1981. p. 126-162.

GRIMES, K. A.; MOHAMED, J. A.; DUPONT, H. L.; PADDA, R. S.; JIANG, Z. D.; FLORES, J.; BELKIND-GERSON, J.; MARTINEZ-SANDOVAL, F. G.; OKHUYSEN, P, C. PCR-based assay using occult blood detection cards for detection of diarrheagenic Escherichia coli in specimens from U.S. travelers to Mexico with acute diarrhea. J. Clin. Microbiol., v.46, p. 2227-30, 2008.

KAHALI, S.; SARKAR, B.; RAJENDRAN, K.; KHANAM, J.; YAMASAKI, S.; NANDY, R.K.; BHATTACHARYA, S.K.; RAMAMURTHY,T. Virulence characteristics and molecular epidemiology of enteroaggregative Escherichia coli isolates from hospitalized diarrheal patients in Kolkata, India. J. Clin. Microbiol., v. 42, p. 4111-20, 2004.

HARADA, T.; HIROI, M.; KAWAMORI, F.; FURUSAWA, A.; OHATA, K.; SUGIYAMA, K.; MASUDA, T. A food poisoning diarrhea outbreak caused by enteroaggregative Escherichia coli serogroup 0126:H27 in Shizuoka, Japan. Jpn. J. Infect. Dis., v. 60, p. 154-5, 2007.

HARRINGTON, S. M.; DUDLEY, E. G.; NATARO, J. P. Pathogenesis of enteroaggregative Escherichia coli infection. FEMS Microbiol. Lett., v. 254, p.1218, 2006. 
HEILMANN, C.; SCHWEITZER, O.; GERKE, C.; VANITTANAKOM, N.; MACK, D.; GÖTZ, F. Molecular basis of intercellular adhesion in the biofilm-forming Sthaphylococcus epidermidis. Mol. Microbiol., v. 20, p. 1083-1091, 1996.

HEIMER, S. R.; RASKO, D. A.; LACKATELL, C. V.; JOHNSON, D. E.; MOBLEY, H. L. T. Autotransporter genes pic and tsh are associated with Escherichia coli strains that cause acute pyelonephritis and are expressed during urinary tract infection. Infect. Immun., v. 72, p. 593-597, 2004.

HENDERSON, I. R.; CZECZULIN, J.; ESLAVA, C.; NORIEGA, F.; NATARO, J. $P$. Charactezation of Pic, a secreted protease of Shigella flexneri and enteroagregative Escherichia coli. Infect. Immun., v. 67, p. 5587-5596, 1999.

HENDERSON, I. R.; NAVARRO-GARCIA, F.; NATARO, J. P. The great escape: structure and function of the autotransporter proteins. Trends Microbiol.; v. 6, p. 370-378, 1998.

HICKS, S.; CANDY, D. C. A.; PHILIPS, A. D. Adhesion of enteroaggregative Escherichia coli pediatric intestinal mucosa in vitro. Infect. Immun., v. 64, p. 4751-4760, 1996.

HUANG, D. B.; MOHANTY, A.; DUPONT, H. L.; OKHUYSEN, P. C.; CHIANG, $\mathrm{T}$. A review of emerging enteric pathogen: enteroaggregative Escherichia coli. J. Med. Microbiol., v. 55, p. 1303-11, 2006.

ITOH, Y.; NAGANO, I.; KUNISHIMA, M.; EZAKI, T. Laboratory investigation of enteroaggregative Escherichia coli $\mathrm{O}$ untypeable: $\mathrm{H} 10$ associated with a massive outbreak of gastrointestinal illness. J. Clin. Microbiol., v. 35, p. 25462550, 1997.

JAFARI, F.; GARCIA-GIL, L. J.; SALMANZADEH-AHRABI, S.; SHOKRZADEH, L.; ASLANI, M. M.; POURHOSEINGHOLI, M. A.; DERAKHSHAN, F.; ZALI, M. $R$. Diagnosis and prevalence of enteropathogenic bacteria in children less than 5 years of age with acute diarrhea in Tehran children's hospitals. J. Infect., v. 58 , p. 21-27, 2009.

JENKINS, C.; CHART, H.; WILLSHAW, G. A.; CHEASTY, T.; SMITH, H. Genotyping of enteroaggregative Escherichia coli of both typical and atypical strains. Diag. Microbiol. Infect. Dis., v. 55, p. 13-19, $2006 a$.

JENKINS, C.; TEMBO, M.; CHART, H.; CHEASTY, T.; WILLSHAW, G. A.; PHILLIPS, A. D.; TOMPKINS, D.; SMITH, H. Detection of enteroaggregative Escherichia coli in faecal samples from patients in the community with diarrhea. J. Med. Microbiol., v. 55, p. 1493-1497, 2006b.

JIANG, Z. D.; GREENBERG, D.; NATARO, J. P.; STEFFEN, R.; DUPONT, H. $\mathrm{L}$. Rate of occurrence and pathogenic effect of enteroaggregative Escherichia coli virulence factors in intestinal travelers. J. Clin. Microbiol., v. 40, p. 41854190, 2002. 
JOHNSON, J. R. Virulence factors in Escherichia coli urinary tract infection. Clin. Microbiol. Rev., v. 4, p. 80-128, 1991.

KAPER, J. B. Defining enteropathogenic Escherichia coli. Rev. Microbiol., v. 27, p. 130-133, 1996.

KAPER, J. B.; NATARO, J. P.; MOBLEY, H. L. T. Pathogenic Escherichia coli. Nat. Rev. Microbiol., v. 2, p. 123-138, 2004.

KELLY, P.; HICKS, S.; OLOYA, J.; MWANSA, J.; SIKAKWA, L.; ZULU, I.; PHILLIPS, A. Escherichia coli enterovirulent phenotypes in Zambians with AIDS-related diarrhoea. Trans. R. Soc. Trop. Med. Hyg., v.97, p. 573-576, 2003.

KESKIMÄKI, M.; EKLUND, M.; PESONEN, H.; HEISKANEN, T.; SIITONEN, A. EPEC, EAEC and STEC in stool specimens: prevalence and molecular epidemiology of isolates.Diag. Microbiol. Infect .Dis., v.40, p. 151-156, 2001.

KNUTTON, S.; SHAW, R. K.; BHAN, M. K.; SMITH, H. R.; MCCONNELL, M. M.; CHEASTY, T.; WILLIAMS, P. H.; BALDWIN, T. J. Ability of enteroaggregative Escherichia coli strains to adhere in vitro to human intestinal mucosa. Infect. Immun., v. 60, p. 2083-2091, 1992.

KOO, H. L.; JIANG, Z. D.; BROWN, E.; GARCIA, C.; QI, H.; DUPONT, H. L. Coliform contamination of vegetables obtained from popular restaurants in Guadalajara, Mexico, and Houston, Texas. Clin. Infect. Dis., v. 47, p. 218-221, 2008.

LABIGNE-ROUSSEL, A; FALKOW, S. Distribution and degree of heterogeneity of the afimbrial-adhesin-encoding operon (afa) among uropathogenic Escherichia coli isolates. Infect. Immun., v. 56, p. 640-648, 1988.

LEVINE, M. M. Escherichia coli that cause diarrhea: enterotoxigenic, enteropathogenic, enteroinvasive, enterohemorrhagic, and enteroadherent. J. Infect. Dis., v. 155, p. 377-389, 1987.

LIMA, A. A.; FANG, G.; SCHORLING, J. B.; DE ALBUQUERQUE, L.; MCAULIFFE, J. F.; MOTA, S.; LEITE, R.; GUERRANT, R. L. Persistent diarrhea in northeast Brazil: etiologies and interactions with malnutrition. Acta Pedriat. Suppl., v. 381, p. 39-44, 1992.

MATHEWSON, J. J., JOHNSON, P. C., DUPONT, H. L.; MORGAN, D. R.; THORNTON, S. A.; WOOD, L. V.; ERICSSON, C. D. A newly recognised cause of travellers' diarrhea: enteroadherent Escherichia coli. J. Infec. Dis., v. 151, p. 471-475, 1985.

MOHAMED, J. A.; HUANG, D. B.; JIANG, Z. D.; DUPONT, H. L.; NATARO, J. P.; BELKIND-GERSON, J.; OKHUYSEN, P. C. Association of putative enteroaggregative Escherichia coli virulence genes and biofilm production in 
isolates from travelers to developing countries. J. Clin. Microbiol., v. 45, p. 121-126, 2007.

MONTEIRO-NETO, V.; BANDO, S. Y.; MOREIRA-FILHO, C. A; GIRON, J. A. Characterization of an outer membrane protein associated with haemagglutination and adhesive properties of enteroaggregative Escherichia coli O111:H12. Cell. Microbiol., v.5, p.533-547, 2003.

MOON, H. W.; WHIPP, S. C.; ARGENZIO, R. A.; LEVINE, M. M.; GIANNELLA, R. A. Attaching and effacing activities of rabbit and human enteropathogenic Escherichia coli in pig and rabbit intestines. Infect. Immun., v. 41, p. 13401351, 1983.

MOREIRA, C. G. Fatores de virulência e o papel da fímbria tipo I na adesão agregativa de amostras de Escherichia coli do sorotipo 0128:H35. Dissertação (Mestrado) - Instituto de Ciências Biomédicas, Universidade de São Paulo, São Paulo, 2001.

MOREIRA, C. G.; CARNEIRO, S. M.; NATARO, J. P.; TRABULSI, L. R.; ELIAS, W. P. Role of type I fimbriae in the aggregative adhesion pattern of enteroaggregative Escherichia coli. FEMS Microbiol. Lett., v. 226, p. 79-85, 2003.

MOREIRA, F. C.; VIEIRA, M. A. M.; FERREIRA, A. J. P.; GIRÃO, D. M.; VAZ, T. M. I.; ROSA, C. P.; KNOBL, T.; IRINO, K.; FREYMÜLLER, E.; GOMES, T. A. T. Escherichia coli strains of serotype O151:H40 comprise typical and atypical enteropathogenic $E$. coli strains and are potentially diarrheagenic. J. Clin. Microbiol., v. 46, p. 1462-1465, 2008.

MORENO, A. C. R.; FERNANDES-FILHO, A.; GOMES, T. A. T.; RAMOS, S. T. S.; MONTENOR, L. P. G.; TAVARES, V. C.; SANTOS-FILHO, L.; IRINO, K.; MARTINEZ, M. B. Etiology of childhood in the northeast of Brazil: significant emergent diarrheal pathogens. Diag. Microbiol. Infect. Dis., 2008. In press. doi: 10.1016/j.diagmicrobio.2008.03.017).

MOSSORO, C.; GLAZIOU, P.; YASSIBANDA, S.; LAN, N. T.; BEKONDI, C.; MINSSART, P.; BERNIER, C.; LE BOUGUÉNEC, C.; GERMANI, Y. Chronic diarrhea, hemorrhagic colitis, and hemolytic-uremic syndrome associated with HEp-2 adherent Escherichia coli in adults infected with human immunodeficiency virus in Bangui, Central African Republic. J. Clin. Microbiol., v. 40, p. 3086-8, 2002.

NAKATA, N.; SASAKAWA, C.; OKADA, N.; TOBE, T.; FUKUDA, I..; SUZUKI, T.; KOMATSU, K.; YOSHIKAWA, M. Identification and characterization of virK, a virulence-associated large plasmid gene essential for intercellular spreading of Shigella flexneri. Mol. Microbiol., v. 6, p. 2387-2395, 1992.

NATARO, J. P.; BALDINI, M. M.; KAPER, J. B.; BLACK, R. E.; BRAVO, N.; LEVINE, M. M. Detection of an adherence factor of enteropathogenic Escherichia coli with a DNA probe. J. Infect. Dis., v. 152, p.560-5, 1985. 
NATARO, J.P.; DENG, Y.; COOKSON, S.; CRAVIOTO, A.; SAVARINO, S. J.; GUERS, L. D.; LEVINE, M. M.; TACKET, C. O. Heterogeneity of enteroaggregative Escherichia coli virulence demonstrated in volunteers. J. Infect. Dis., v. 171, p. 465-4688, 1995.

NATARO, J. P.; DENG, Y.; MANEVAL, D. R.; GERMAN, A. L.; MARTIN, W. C.; LEVINE, M. M. Aggregative adherence fimbriae I of enteroaggregative Escherichia coli mediate adherence to HEp-2 cells and hemagglutination of human erythrocytes. Infect. Immun., v. 60, p. 2297-2304, 1992.

NATARO, J. P.; KAPER, J. B. Diarrheagenic Escherichia coli. Clin. Microbiol. Rev., v. 11, p. 142-201, 1998.

NATARO, J. P.; KAPER, J. B.; ROBINS-BROWNE, R.; PRADO, V.; VIAL, P. A.; LEVINE, M. M. Patterns of adherence of diarrheagenic Escherichia coli to HEp-2 cells. Pediatr. Infect. Dis. J., v. 16, p. 829-831, 1987.

NATARO, J. P.; MAI, V.; JOHNSON, J.; BLACKWELDER, W. C.; HEIMER, R.; TIRRELL, S.; EDBERG, S. C.; BRADEN, C. R.; GLENN MORRIS, J. J. R.; HIRSHON, J. M. Diarrheagenic Escherichia coli infection in Baltimore, Maryland, and New Haven, Connecticut. Clin. Infect. Dis., v. 43, p. 402-407, 2006.

NATARO, J. P.; SERIWATANA, J.; FASANO, A.; MANEVAL, D. R.; GUERS, L. D.; NORIEGA, F.; DUBOVSKY, F.; LEVINE, M. M.; MORRIS, J. G. JR. Identification and cloning of a novel plasmid-encoded enterotoxin of enteroinvasive Escherichia coli and Shigella strains. Infect. Immun., v. 63, p. 4721-4728, 1995.

NATARO, J. P.; STEINER, T.; GUERRANT, R. L. Enteroaggregative Escherichia coli. Emerg. Infect. Dis., v. 4, p. 251-261, 1998.

NATARO, J. P.; YKANG, D.; YNGKANG, D.; WALKER, K. AggR, a transcriptional activator of aggregative adherence fimbria I expression in enteroaggregative Escherichia coli. J. Bacteriol., v. 176, p. 4691-4699, 1994.

NAVARRO-GARCIA, F.; ESLAVA, C.; VILLASECA, J. M.; LÓPEZ-REVILLA, R.; CZECZULIN, J. R.; SRINIVAS, S.; NATARO, J. P.; CRAVIOTO, A. In vitro effects of a high-molecular weight heat-labile enterotoxin from enteroaggregative Escherichia coli. Infect. Immun., v. 66, p. 3149-3154, 1998.

NAVARRO-GARCIA, F.; SEARS, C.; ESLAVA, C.; CRAVITO, A.; NATARO, J. P. Cytoskeletal effects induced by pet, the serino protease enterotoxin of enteroaggregative Escherichia coli. Infect. Immun., v. 67, p. 2184-2192, 1999.

NGUYEN, T. V.; VAN, P. L.; HUY, C. L.; NGUYEN-GIA, K.; WEINTRAUB, A. Detection and characterization of diarrheagenic Escherichia coli from young children in Hanoi, Vietnam. J. Clin. Microbiol., v.43, p. 755-760, 2005. 
NISHI, J.; SHEIKH, J.; MIZUGUCHI, K.; LUISI, B.; BURLAND, V.; BOUTIN, A.; ROSE, D. J.; BLATTNER, F. R.; NATARO, J. P. The export of coat protein from enteroaggregative Escherichia coli by a specific ATP-binding cassette transporter system. J. Biol. Chem., v. 278, p. 45680-45689, 2003.

NOVERR, C. M.; HUFFNAGLE, G. B. Does the microbiota regulate immune responses outside the gut? Trends Microbiol., v. 12, p. 562-568, 2004.

OKEKE, I. N.; LAMIKANRA, A.; CZECZULIN, J.; DUBOVSKY, F.; KAPER, J. B.; NATARO, J. P. Heterogeneous virulence of enteroaggregative Escherichia coli strains isolated from children in Southwest Nigeria. J. Infect. Dis., v. 181, p. 252-60, 2000.

OKEKE, I. N.; NATARO, J. P. Enteroaggregative Escherichia coli. Lancet, v. 1, 304-313, 2001.

OKEKE, I. N.; OJO, O.; LAMOKANRA, A.; KAPER, J. B. Etiology of acute diarrhea in adults in southwestern Nigeria. J. Clin. Microbiol., v. 41, p. 452530, 2003.

PABST, W. L.; ALTWEGG, M.; KIND, C.; MIRJANIC, S.; HARDEGGER, D.; NADAL, D. Prevalence of enteroaggregative Escherichia coli among children with and without diarrhea in Switzerland. J. Clin. Microbiol., v. 41, p. 22892293, 2003.

PAI, M.; KANG, G.; RAMAKRISHMA, B. S.; VENKATARAMAN, A.; MULIYIL, J. An epidemic of diarrhoea in south India caused by enteroaggregative Escherichia coli. Indian J. Med. Res., v. 106, p. 7-12, 1997.

PARSOT, C. Shigella spp. and enteroinvasive Escherichia coli pathogenicity factors. FEMS Microbiol. Lett., v. 252, p. 11-18., 2005.

PAUL, M.; TSUKAMOTO, T.; GHOSH, A. R.; BHATTACHARYA, S. K.; MANNA, B.; CHAKRABARTI, S.; NAIR, G. B.; SACK, D. A.; SEN, D.; TAKEDA, $Y$. The significance of enteroaggregative Escherichia coli in the etiology of hospitalized diarrhoea in Calcutta, India, and the demonstration of a new honeycombed pattern of aggregative adherence. FEMS Microbiol. Lett., v. 117, p. 319-326, 1994.

PEMFOLD, R. J.; PEMBERTON, J. M. An improved suicide vector for construction of chromosomal insertion mutations in bacteria. Gene, v. 118, p. 145-146, 1992.

PEREIRA, A. C.; BRITTO-FILHO, J. D.; CARVALHO, J.; DE LUNA, M. G.; ROSA, A. C. Enteroaggregative Escherichia coli (EAEC) strains enter and survive within cultured intestinal epithelial cells. Microb. Pathog., v. 45, p. 310314, 2008. 
PETRI, W. A.; MILLER, M.; BINDER, H. J.;LEVINE, M. M.; DILLINGHAM, R.; GUERRANT, R. L. Enteric infections, diarrhea, and their impact on function and development. J. Clin. Invest., v. 118, p. 1277-1290. 2008.

PINTO, M.; ROBINE-LEON, S.; APPAY, M. D.; KEDINGER, M.; TRIADOU, N.; DUSSAULX, E.; LACROIX, B.; SIMON-ASSMAN, P.; HAFFEN, K.; FOGH, J.; ZWEIBAUM, A. Enterocyte-like differentiation and polarization of the human colon carcinoma cell line Caco-2 in culture. Cell, v. 47, p. 323-330, 1983.

PIVA, I.C.; PEREIRA, A. L.; FERRAZ, L. R.; SILVA, R. S. N.; VIEIRA, A. C.; BLANCO, J. E.; BLANCO, M.; BLANCO, J.; GIUGLIANO, L. G. Virulence markers of enteroagregative Escherichia coli from children and adults with diarrhea in Brasília, Brazil. J. Clin. Microbiol., v. 41, p. 1827-1832, 2003.

PUKATZKI, S.; MA, A. T.; STURTEVANT, D.; KRASTINS, B.; SARRACINO, D.; NELSON, W. C.; HEIDELBERG, J. F.; MEKELANOS, J. J. Identification of a conserved bacterial protein secretion system in Vibrio cholerae using the Dictyostelium host model system. Proced. Natl. Acad. Sci. USA, v. 103, p. 1528-1533, 2006.

RAJAKUMAR, K.; LUO, F.; SASAKAWA, C.; ADLER, B. Evolucionary perspective on a composite Shigella flexneri 2 a virulence plasmid-borne locus comprising three distinct genetic elements. FEMS Microb. Lett., v. 144, p. 1320, 1996.

RASKO, D. A.; ROSOVITZ, M. J.; MYERS, G. S.; MONGODIN, E. F.; FRICKE, W. F.; GAJER, P.; CRABTREE, J.; SEBAIHIA, M.; THOMSON, N. R.; CHAUDHURI, R.; HENDERSON, I. R.; SPERANDIO, V.; RAVEL, J. The pangenome structure of Escherichia coli: comparative genomic analysis of $E$. coli commensal and pathogenic isolates. J. Bacteriol., v. 190, p. 6881-93, 2008.

RAO, P. S.; YAMADA, Y.; TAN, Y. P.; LEUNG, K. Y. Use of proteomics to identify novel virulence determinants that are required for Edwardsiella tarda pathogenesis. Mol. Microbiol., v.53, p. 573-586, 2004.

REGUA-MANGIA, A. H.; GOMES, T. A. T.; VIEIRA, M. A. M.; ANDRADE, J. R.; IRINO, K.; TEIXEIRA, L. M. Frequency and characteristics of diarrhoeagenic Escherichia coli strains isolated from children with and without diarrhoea in Rio de Janeiro, Brazil. J. Infect., v.48, p. 161-167, 2004.

REGUA-MANGIA, A. H.; GOMES, T. A. T.; VIEIRA, M. A. M.; IRINO, K.; TEIXEIRA, L. M. Molecular typing and virulence of enteroaggregative Escherichia coli strains isolated from children with and without diarrhea in Rio de Janeiro city, Brazil. J. Med. Microbiol., v. 58, p. 414-422, 2009.

RILEY, L. M.; TEMIS, R. S.; HLGERSON, S. D.; McGEE, H. B.; WELLS, J. G.; DAVIS, B. R.; HEBERT, R. J.; OLCOTT, E. S.; JOHNSON, L. M. Hemorrhagic colitis assocated with a rare Escherichia coli serotype. New Engl. J. Med., v. 308, p. 681-685, 1983. 
ROBINS-BROWNE, R. M.; BORDUN, A. M.; TAUSCHEK, M.; BENNETTWOOD, V. R.; RUSSEL, J.; OPPEDISANO, F.; LISTER, N. A.; BETTELHEIM, K. A.; FAIRLEY, C. K.; SINCLAIR, M. I.; HELLARD, M. E. Escherichia coli and community-acquired gastroenteritis, Melbourne, Australia. Emerg. Infect. Dis., v. 10, p. 1797-1805, 2004.

RODRIGUES, J.; ACOSTA, V. C.; CANDEIAS, J. M.; SOUZA, L. O.; FILHO, F. $\mathrm{J}$. Prevalence of diarrheogenic Escherichia coli and rotavirus among children from Botucatu. Braz. J. Med. Biol. Res., v. 35, p. 1311-1318, 2002.

RODRIGUES, J; SCALETSKY, I. C. A.; CAMPOS, M L. C.; GOMES, T. A. T.; WHITTAM, T. S.; TRABULSI, L. R. Clonal structure and virulence factors in strains of Escherichia coli of the classic serogroup O55. Infect. Immun., v. 64, p. 2680-2686, 1996.

RUSSO, T. A.; JOHNSON, J. R. Proposal for a new inclusive designation for extraintestinal pathogenic isolates of Escherichia coli: ExPEC. J. Infect. Dis., v. 181 , p. 1753-54, 2000.

RÜTLER, M. E.; YANZÓN, M. J.; CUITIÑO, N. F. R.; PIZARRO, M. A.; ORTIZ, A. M. Evolutin of a multiplex PCR method to detect enteroaggregative Escherichia coli. Biocell, v. 30, p. 301-308, 2006.

SAMBROOK, J., FRITSCH, E.F., MANIATIS, T. Molecular Cloning: a Laboratory Manual. New York: Cold Spring Harbor, 1989.

SAMIE, A.; OBI, C. L.; DILLINGHAM, R.; PINKERTON, R. C.; GUERRANT, R. L. Enteroaggregative Escherichia coli in Venda, South Africa: distribution of virulence-related genes by multiplex polymerase chain reaction in stool samples of human Immunodeficiency virus (HIV)-positive and HIV-negative individuals and primary school children. Am. J. Trop. Med. Hyg., v. 77, p. 142-150, 2007.

SARANTUYA, J.; NISHI, J.; WAKIMOTO, N.; ERDENE, S.; NATARO, J.P.; SHEIKH, J.; IWASHITA, M.; MANAGO, K.; TOKUDA, K.; YOSHINAGA, M.; MIYATA, K.; KAWANO, Y. Typical enteroaggregative Escherichia coli is the most prevalent pathotype among E. coli strains causing diarrhea in Mongolian children. J. Clin. Microbiol., v. 42, p. 133-139, 2004.

SAVARINO, S. J.; FASANO, A; ROBERTSON, D. C.; LEVINE, M. M. Enteroaggregative Escherichia coli elaborate a heat-stable enterotoxin demonstrable in a in vitro rabbit intestinal model. J. Clin. Invest., v. 87, p. 1450-1455, 1991.

SAVARINO, S. J.; FASANO, A; WATSON, J.; MARTIN, B. M.; LEVINE, M. M.; GUANDALINI, S.; GUERRY, P. Enteroaggregative Escherichia coli heat-stable enterotoxin 1 represents another subfamily of $E$. coli heat-stable toxin. Proc. Natl. Acad. Sci. USA, v. 90, p. 3093-3097, 1993.

SAVARINO, S. J.; FOX, P.; YIKANG, D.; NATARO, J. P. Identification and charcterization of a gene cluster mediating enteroaggregative Escherichia coli 
aggregative adherence fimbria I biogenesis. J. Bacteriol., v. 176, p. 4949-4957, 1994.

SAVARINO, S. J.; MCVEIGH, A.; WATSON, J.; MOLINA, J.; CRAVIOTO, A.; ECHEVERRIA, P.; BHAN, M. K.; LEVINE, M. M.; FASANO, A. Enteroaggregative Escherichia coli heat-stable enterotoxin is not restricted to enteroaggregative Escherichia coli. J. Infect. Dis., v. 173, p. 1019-1022, 1996.

SCALETSKY, I. C.; FABBRICOTI, S. H.; CARVALHO, R. L.; NUNES, C. R.; MARANHÃO, H. S.; MORAIS, M. B.; FAGUNDES-NETO, U. Diffusely adherent Escherichia coli as a cause of acute diarrhea in young children in Northeast Brazil: a case-control study. J. Clin. Microbiol., v. 40, p. 645-648, $2002 a$.

SCALETSKY, I. C.; FABBRICOTI, S. H.; SILVA, S. O.; MORAIS, M. B.; FAGUNDES-NETO, U. HEp-2-adherent Escherichia coli strains associated with acute diarrhea, São Paulo, Brazil. Emerg. Infect. Dis., v. 8, p. 855-858, 2002 b.

SCALETSKY, I. C.; SILVA, M. L. M.; TRABULSI, L. R. Distinctive patterns of adherence of enteropathogenic Escherichia coli to HeLa cells. Infect. Immun., v. 45, p. 534-36, 1984.

SCOTLAND, S. M.; WILLSHAW, G. A.; CHEASTY, T.; ROWE, B.; HASSALL, J. E. Association of enteroaggregative Escherichia coli with travellers' diarrhea $\mathbf{J}$. Infect., v. 29, p. 115-6, 1994.

SCHMIDT, H.; KNOP, C.; FRANKE, S.; ALEKSIE, S.; HEESEMAN, J.; KARCH, $\mathrm{H}$. Development of PCR for screening of enteroaggregative Escherichia coli. J. Clin. Microbiol., v. 33, p. 701-705, 1995.

SCHUBERT, S.; RAKIN, A.; KARCH, A.; CARNIEL, E.; HEESEMANN, J. Prevalence of the high-pathogenicity island of Yersinia species among Escherichia coli strains that are pathogenic to humans. Infect. Immun., v. 66, p. 480-485, 1998.

SCHULTZ, C.; VAN DEN ENDE, J.; COBELENS, F.; VERVOORT, T.; VAN GOMPEL, A.; WETSTEYN, J. C.; DANKERT, J. Diarrheagenic Escherichia coli and acute and persistent diarrhea in returned travelers. J. Clin. Microbiol., v. 38 , p. 3550-4, 2000.

SERVIN, A. L. Pathogenesis of Afa/Dr diffusely adhering Escherichia coli. Clin. Microbial. Rev., v. 18, p. 264-292, 2005.

SHEIKH, J.; CZECZULIN, J. R.; HARRINGTON, S.; HENDERSON, I. R.; LE BOUGUÉNEC, C.; GOUNON, P.; PHILLIPS, A.; NATARO, J. P. A novel dispersin protein in enteroaggregative Escherichia coli. J. Clin. Invest., v. 110, p. 1329-37, 2002.

SHEIKH, J.; HICKS, S.; DALL'AGNOL, M.; PHILLIPS, A. D.; NATARO, J. P. Roles for Fis and YafK in biofilm formation by enteroaggregative Escherichia coli. Mol. Microbiol., v. 41, p. 983-997, 2001. 
SMITH, H. R.; CHEASTY, T.; ROWE, B. Enteroaggregative Escherichia coli and outbreaks of gastroenteritis in UK. Lancet, v. 350, p. 814-815, 1997.

SMITH, H. R.; SCOTLAND, S. M.; WILLSHAW, G. A.; ROWE, B.; CRAVIOTO, A.; ESLAVA, C. Isolates of Escherichia coli O44:H18 of diverse origin are enteroaggregative. J. Infect. Dis., v. 170, p. 1610-1613,1994.

SPENCER, J.; SMITH, H. R.; CHART, H. Characterization of enteroaggregative Escherichia coli isolated from outbreaks of diarrhoeal disease in England. Epidemiol. Infect., v. 123, p. 413-21, 1999.

SPEZIALE, P.; VISAI, L.; RINDI, S.; PIETROCOLA, G.; PROVENZA, G.; PROVENZANO, M. Prevention and treatment of Staphylococcus biofilms. Curr. Med. Chem., v. 15, p. 3185-3195, 2008.

STEINER, T. S.; LIMA, A. A. M.; NATARO, J. P.; GUERRANT, R. L. Enteroaggregative Escherichia coli produce intestinal inflammation and growth impairment and cause interleukin-8 release from intestinal epithelial cells. J. Infect. Dis., v. 177, p. 88-96, 1998.

STEWART, P. S.; COSTERTON, J. W. Antibiotic resistance of bacteria in biofilms. Lancet, v. 358, p.135-8, 2001.

SUZART, S.; GUTH, B. E. C.; PEDROSO, M. Z.; OKAFOR, U. M.; GOMES, T. A. $T$. Diversity of surface structures and virulence genetic markers among enteroaggregative Escherichia coli (EAEC) strains with and without the EAEC DNA probe sequence. FEMS Microbiol. Lett., v. 201, p. 163-168, 2001.

SVENUNGSSON, B.; LAGERGREN, A.; EKWALL, E.; EVENGÅRD, B.; HEDLUND, K. O.; KÄRNELL, A.; LÖFDAHL, S.; SVENSSON, L.; WEINTRAUB, A. Enteropathogens in adult patients with diarrhea and healthy control subjects: a year prospective study in a Swedish clinic for infectious disease. Clin. Infect. Dis., v. 30,p. $770-8,2000$.

TRABULSI, L. R.; KELLER, R.; GOMES, T.A.T. Typical and atypical enteropathogenic Escherichia coli. Emerg. Infect. Dis., v. 8, p. 508-513, 2002.

TZIPORI, S.; MONTANARO, J.; ROBINS-BROWNE, R. M.; VIAL, P.; GIBSON, R. Studies with enteroaggregative Escherichia coli in the gnotobiotic piglet gastroenteritis model. Infect. Immun., v. 60, p. 5302-5306, 1992.

UBER, A. P.; TRABULSI, L. R.; IRINO, K.; BEUTIN, L.; GHILARDI, A. C. R.; GOMES, T. A. T.; LIBERATORE, A. M. A.; CASTRO, A. F. P.; ELIAS, W. P. Enteroaggregative Escherichia coli from humans and animals differ in major phenotypical traits and virulence genes. FEMS Microbiol. Lett., v. 256, p. 251257, 2006.

VEILLEUX, S.; HOLT, N.; SCHULTZ, B. D.; DUBREUIL, J. D. Escherichia coli EAST1 toxin toxicity of variants 17-2 and O 42. Comp. Immunol. Microbiol. Infect. Dis., v. 31, p. 567-578, 2008. 
VELARDE, J. J.; VARNEY, K. M.; INMAN, K. G.; FARFAN, M.; DUDLEY, E.; FLETCHER, J.; WEBER, D. J.; NATARO, J. P. Solution structure of the novel dispersin protein of enteroaggregative Escherichia coli. Mol. Microbiol., v. 66, p. 1123-1135, 2007.

VERNACCHIO, L.; VEZINA, R. M.; MITCHELL, A. A.; LESKO, S. M.; PLAUT, A. G.; ACHESON, D. W. Diarrhea in American infants and young children in the community setting: incidence, clinical presentation and microbiology. Pediatr. Infect. Dis. J., v. 25, p. 2-7, 2006.

VIAL, P.A.; ROBINS-BROWNE, R.; LIOR, H.; PRADO, V.; KAPER, J.B.; NATARO, J.P.; MANEVAL, D.; ELSAYED, A.; LEVINE, M. M. Characterization of enteroadherent-aggregative Escherichia coli, a putative agent of diarrheal disease. J. Infect. Dis., v. 158, p. 70-79, 1988.

VUONG, C.; KOCIANOVA, S.; VOYICH, J. M.; YAO, Y.; FISCHER, E. R.; DELEO, F. R.; OTTO, M. A crucial role for exopolysaccharide modification in bacterial biofilm formation, immune evasion, and virulence. J. Biol. Chem., v. 279, p. 54881-54886, 2004.

WAI, S. N.; TAKADE, A.; AMAKO, K. The hydrophobic surface protein layer of enteroaggregative Escherichia coli strains. FEMS Microbiol. Lett., v. 135, p. 17-22, 1996.

WAKIMOTO, N.; NISHI, N.; SHEIKH, J.; NATARO, J. P.; SARANTUYA, J.; IWASHITA, M.; MANAGO, K.; TOKUDA, K.; YOSHINAGA, M.; KAWANO, Y. Quantitative biofilm assay using a microtiter plate to screen for enteroaggregative Escherichia coli. Am. J. Trop. Med. Hyg., v. 71, p. 687-690, 2004.

WATNICK, P. I.; KOLTER, R. Steps in the development of a Vibrio cholerae EI Tor biofilm. Mol. Microbiol., v. 34, p. 586-95, 1999.

WEINTRAUB, A. Enteroaggregative Escherichia coli: epidemiology, virulence and detection. J. Med. Microbiol., v. 56, p. 4-8, 2007.

WHITTAKER, C. J.; KLIER, C. M.; KOLENBRANDER, P. E. Mechanisms of adhesion by oral bacteria. Annu. Rev. Microbiol., v 50, p. 513-52, 1996.

ZAMBONI, A.; FABRICOTTI S. H.; FAGUNDES-NETO, U.; SCALETSKY, I. C. A. Enteroaggregative Escherichia coli virulence factors are found to be associated with infantile diarrhea in Brazil. J. Clin. Microbiol., v. 42, p. 10581063, 2004. 